\title{
The primate fossil record in the Iberian Peninsula
}

\author{
J. Marigón ${ }^{1,2}$, I. Susanna ${ }^{1}$, R. Minwer-Barakatt ${ }^{1}$, J. Madurell-Malapeira' ${ }^{1}$ S. Moyà-Solà ${ }^{3}$, I. \\ Casanovas-Vilar ${ }^{1}$, J. M. Robles ${ }^{1,4}$, D.M. Alba ${ }^{1, *}$
}

\begin{abstract}
${ }^{1}$ Institut Català de Paleontologia Miquel Crusafont, Universitat Autònoma de Barcelona. Edifici ICP, Campus de la UAB s/n, 08193 Cerdanyola del Vallès, Barcelona, Spain.

${ }^{2}$ Department of Evolutionary Anthropology, Duke University, 130 Science Drive, Durham, NC 27708, USA.

${ }^{3}$ ICREA at Institut Català de Paleontologia Miquel Crusafont and Unitat d'Antropologia Biologica (Departament BABVE), Universitat Autònoma de Barcelona, Edifici ICP, Campus de la UAB s/n, 08193 Cerdanyola del Vallès, Barcelona, Spain. ${ }^{4}$ FOSSILIA Serveis Paleontolòics i Geològics, S.L. Jaume I 87, 1er 5ª 08470 Sant Celoni, Barcelona, Spain.
\end{abstract}

e-mail addresses: david.alba@icp.cat (D.M.A., *correspondingauthor),judit.marigo@duke.edu (J.M.),ivette.susanna@icp.cat (I.S.),raef.minwer@icp.cat
(R.M.-B.),joan.madurell@icp.cat (J.M.-M.), salvador.moya@icp.cat (S.M.-S.), isaac.casanovas@icp.cat (I.C.-V.),josep.robles@fossilia.com (J.M.R.)

Received: 26 July 2013 / Accepted: 5 December 2013 / Available online: 25 February 2014

\begin{abstract}
During the last decade, new discoveries in several Iberian basins, together with the description of previously unpublished finds, have significantly increased the recorded paleodiversity of fossil Primates (Mammalia: Euarchonta) in the Iberian Peninsula. Here we provide an updated compendium of the primate fossil record in Iberia during the Cenozoic and further summarize the changes in primate paleodiversity through time, which are then analyzed in the light of changing climatic conditions. Thanks to favorable climatic conditions, the highest diversity of Iberian primates was reached during the Eocene, thus reflecting the radiation of both adapoids and omomyoids; only a single plesiadapiform genus is in contrast recorded in the Iberian Peninsula. Near the Eocene-Oligocene boundary, paleoclimatic changes led to a primate diversity crisis and other faunal changes, although two Iberian omomyoids survived the Grande Coupure. From the Middle Miocene onwards, catarrhine primates are recorded in the Iberian Peninsula. During the Middle and Late Miocene, they are represented by pliopithecoids and hominoids, restricted to NE Iberia. The Miocene hominoids from Iberia are of utmost significance for understanding the Eurasian hominoid radiation and its role in the origins of the great-ape-and-human clade. Following the local extinction of these taxa during the early Late Miocene, due to progressively increased seasonality and concomitant changes in plant communities, cercopithecoids are also recorded in the Iberian Peninsula from the latest Miocene through the Plio-Pleistocene, although they finally became locally extinct, whereas hominoids are again represented by fossil humans during the Pleistocene.
\end{abstract}

Keywords: Primates, Paleogene, Neogene, Quaternary, Taxonomy, Spain

Resumen

Durante la última década, nuevos descubrimientos en varias cuencas ibéricas, junto con la descripción de hallazgos previos inéditos, han incrementado significativamente la paleodiversidad de Primates fósiles (Mammalia: Euarchonta) registrada en la Península Ibérica. Proporcionamos aquí un compendio actualizado del registro fósil de los primates en Iberia durante el Cenozoico, y resumimos además los cambios en paleodiversidad de los primates a lo largo del tiempo a la luz de las condiciones climáticas cambiantes. Gracias a condiciones climáticas favorables, la diversidad más alta de primates ibéricos se produjo durante el Eoceno, reflejando así la radiación tanto de los adapoideos como de los omomioideos; en cambio, sólo un único género de plesiadapiformes se registra en la Península Ibérica. Hacia el límite Eoceno-Oligoceno, los cambios paleoclimáticos condujeron a una crisis de diversidad de los primates y otros cambios faunísticos, aunque dos omomioideos ibéricos sobrevivieron a la Grande Coupure. Del Mioceno Medio en adelante, los primates catarrinos se registran en la Península Ibérica. Durante el Mioceno Medio y Superior, están representados por pliopitecoideos y hominoideos, restringidos al NE de Iberia. Los hominoideos del Mioceno de Iberia son de gran importancia para comprender la radiación de los hominoideos eurasiáticos y su papel en los orígenes del clado de los grandes antropomorfos y los humanos. A continuación de la extinción local de estos taxones durante el Mioceno Superior inicial, debido al incremento progresivo de la estacionalidad así como a cambios en las comunidades vegetales, los cercopitecoideos también se registran en la Península Ibérica a partir del Mioceno más terminal en adelante. Los cercopitecoideos se registran en la Península Ibérica durante todo el Plio-Pleistoceno, aunque finalmente también se extinguieron localmente, mientras que los hominoideos vuelven a estar representados otra vez por los humanos fósiles durante el Pleistoceno. 


\section{Introduction}

\subsection{Primates}

Primates (Mammalia: Euarchonta) are a eutherian order of moderate diversity, with about 300 extant species. They were traditionally divided into two major groups: prosimians and simians (or anthropoids) (e.g., Fleagle, 1999). Most authors, however, currently favor a distinction between strepsirrhines and haplorrhines. Unfortunately, many of the features that enable such division are related to soft anatomy, so that the classification of fossil 'prosimians' as either strepsirrhines or haplorrhines, albeit favored here, is not always straightforward. Crown primates (euprimates, or primates of modern aspect) constitute a monophyletic group including extant strepsirrhines and haplorrhines, together with the extinct taxa more closely related to either of them (see Fleagle, 1999, and Hartwig, 2002, for the most recent complete accounts on fossil primates). Morphologically, euprimates are characterized by the possession of a petrosal bulla (the auditory bulla is formed by an extension of the petrosal instead of by a separate entotympanic bone), which is a unique synapomorphy among mammals (Rasmussen, 2002). Other derived diagnostic traits of euprimates, uncommon in other mammals, are the following (e.g., Martin, 1990; Rasmussen, 2002): postorbital bar; orbital convergence, yielding stereoscopic binocular vision; grasping hands and feet, usually with opposable hallux and pollex; flat nails instead of claws on most digits; brains larger than expected on the basis of body size (high encephalization); and a slow life-history profile. The primate total group includes crown primates plus the primate stem lineage, the latter being those taxa preceding the haplorrhine-strepsirrhine divergence, but being more closely related to them than to other euarchontans, i.e. scandentians (tree shrews) and dermopterans (flying lemurs). It is generally thought that primates diverged from other mammals sometime during the Late Cretaceous. Undisputed fossil euprimates are not found until the earliest Eocene, ca. $56 \mathrm{Ma}$ (Rasmussen, 2002), and although molecular estimates suggested in the past an ancient divergence data for crown subclades, recent studies suggest that haplorrhines and strepsirrhines diverged close to the Mesozoic/Cenozoic boundary (Steiper and Seiffert, 2012). The origin of euprimates has been related to plesiadapiforms, which show general dental similarities with primates but at the same time lack several euprimate derived features, such as the postorbital bone and the petrosal bulla. The phylogenetic relationships of plesiadapiforms with euprimates remain unresolved, but it seems currently likely that most of them constitute a paraphyletic assemblage of stem primates.

\subsection{Aims of this study}

Most primates are linked to tropical or subtropical forested environments, and currently, modern humans are the only primates naturally inhabiting the Iberian Peninsula. This,

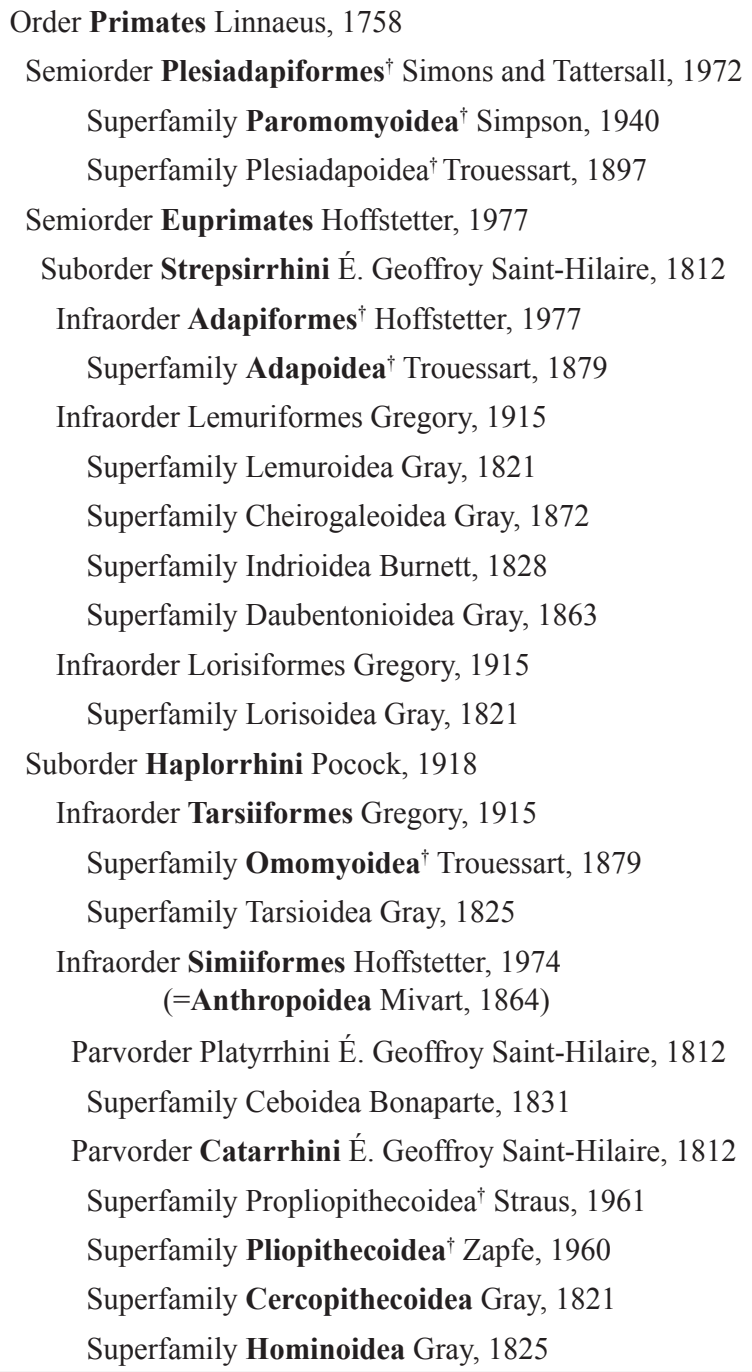

Table 1. Primate systematics down to the superfamily rank. Taxa represented in Iberia are shown in bold type. A dagger $(\dagger)$ denotes extinct taxa.

however, has not always been the case: during the Paleogene and Neogene, several major primate groups occupied the Iberian Peninsula. In Table 1, we have summarized the systematic scheme employed for primates in this paper down to the superfamily rank, indicating with bold bype those taxa recorded in the Iberian Peninsula. For many years, the study of fossil Iberian primates was led by Miquel Crusafont-Pairó, founder of the Institut Català de Paleontologia Miquel Crusafont (ICP), which currently bears his name. Beginning in the early 1940s, Crusafont and co-workers such as Josep F. de Villalta and Juana M. Golpe-Posse reported new material and described new taxa of "prosimians" and anthropoids alike. It is not surprising, therefore, that Crusafont-Pairó and GolpePosse (1974) finally published a synthetic review on the fossil primates from Spain. Since then, some summary syntheses devoted to particular primate groups at the Iberian level have been published (e.g., Moyà Solà et al., 1990; Marigó et al., 2011c), but no detailed and comprehensive synthesis of all Iberian primates has been undertaken since 1974. In 
the meantime, many new fossil discoveries, together with the restudy of previously available material, have led to a significant increase in the knowledge of their paleodiversity, chronology and paleobiology. Here, we provide an updated synthesis of the fossil primates from the Iberian Peninsula (Spain and Portugal) during the Cenozoic (Paleogene, Neogene and Quaternary), enumerating all the recorded taxa at the species level (when possible), and also providing details on their systematics, chronologic and geographic distribution, paleobiology, and phylogenetic relationships. We further discuss the Iberian primate record in the framework of the evolutionary history of this group as a whole, with particular emphasis on its relationship to paleogeographic and climatic changes through time.

\section{Systematic paleontology}

Order Primates Linnaeus, 1758

Semiorder Plesiadapiformes Simons and Tattersall, 1972

Superfamily Paromomyoidea Simpson, 1940

Family Paromomyidae Simpson, 1940

Genus Arcius Godinot, 1984

(Fig. 1A-B)

Arcius sp.

Iberian localities: Masia de l'Hereuet (Lleida).

Remarks: The genus Arcius is mainly known from several Early Eocene (Neustrian, MP7-MP8+9) French sites (Godinot, 1984; Smith et al., 2011), and its Iberian record is comparatively scarce, including only A. zbyszewskii from Silveirinha (Portugal), and Arcius sp. from Masia de l'Hereuet (Spain). The scarce material (only four isolated molars) from the latter locality enable an attribution to the genus Arcius, to which all European paromomyids are currently attributed. This material is intermediate in size between $A$. fuscus and A. lapparenti, and shows several morphological differences compared to all the described species of this genus, but the scarcity of the material precludes erecting a new species.

Main references: Marigó et al. (2012a).

\section{Arcius zbyszewskii Estravís, 2000}

Geographic distribution: Exclusively known from the type locality.

Chronological range: 56-55.5 Ma (MP7, Neustrian, lowermost Eocene).

Iberian localities: Silveirinha [type locality] (Baixo Mondego).

Remarks: Previously attributed to Phenacolemur sp. by Antunes (1981) and Phenacolemur cf. fuscus by Antunes and Russell (1981), A. zbyszewskii is closely related to Arcius rougieri from Palette (France). The Portuguese species is however smaller and displays many other morphologic differences. The phylogenetic relationships between them are unclear.

Main references: Antunes et al. (1997); Estravís (2000).
Semiorder Euprimates Hoffstetter, 1977

Suborder Strepsirrhini É. Geoffroy Saint-Hilaire, 1812

Infraorder Adapiformes Hoffstetter, 1977

Superfamily Adapoidea Trouessart, 1879

Family Notharctidae Trouessart, 1879

Notharctidae indet.

Iberian localities: Silveirinha (Baixo Mondego).

Remarks: Besides Dounrussellia lusitanica, Estravís (2000) reported from Silveirinha some isolated teeth of another notharctid. Due to the scarce material available, this material has been left unassigned at the genus level, even though it resembles the Early Eocene genera Cantius and Donrussellia.

Main references: Antunes et al. (1997); Estravís (2000).

\section{Subfamily Cercamoniinae Gingerich, 1975 \\ Genus Donrussellia Szalay, 1976 \\ Donrussellia lusitanica Estravís, 2000}

Geographic distribution: Exclusively known from the type locality.

Chronological range: 56-55.5 Ma (MP7, Neustrian, lowermost Eocene).

Iberian localities: Silveirinha [type locality] (Baixo Mondego).

Remarks: Donrussellia is the most primitive known adapiform genus, and $D$. lusitanica is a very primitive species within this genus. It is much smaller than D. magna, somewhat larger than $D$. gallica, and of similar size or slightly larger than $D$. provincialis. The lower molars of D. lusitani$c a$ differ from those of the other species of the genus in the smaller paraconid and a shorter trigonid when compared to the talonid. The $\mathrm{M}^{1}$ of $D$. lusitanica differ from those of $D$. provincialis and D. gallica in being larger and in having a more subquadrate outline among other features. Moreover, the nannopithex-fold present in the $\mathrm{M}^{1}$ and $\mathrm{M}^{2}$ of $D$. lusitanica is not present in those attributed to D. gallica, and the absence of a postparaconule crista in the upper molars of $D$. lusitanica makes them different from those of $D$. provincialis.

Main references: Estravís (2000).

\section{Genus Agerinia Crusafont Pairó, 1973 Agerinia sp.}

Iberian localities: La Coma (=La Morera del Monsant 2) (Tarragona); Casa Ramón (Huesca).

Remarks: This genus has been identified in several Spanish and French localities, ranging from the Neustrian (MP8+9) to the Geiseltalian (MP12). The scarce material from Casa Ramón (MP11 or MP12), which consists only of six isolated teeth, precludes erecting a new species, although it is smaller and displays some morphological differences compared to $A$. roselli. The material from La Coma (MP10), also very scarce, is still under study. Since these two localities are of different 
age, it is very plausible that two different species are represented.

Main references: Peláez-Campomanes (1995); Antunes et al. (1997); Marigó et al. (2011c).

\section{Agerinia roselli (Crusafont-Pairó, 1967)}

Geographic distribution: Spain and France.

Chronological range: 51-48.5 Ma (MP10, Grauvian, Early-Middle Eocene).

Iberian localities: Les Saleres [type locality] and Escarlà (Lleida); Can Picantón, Castigaleu, Les Badies and Güell I (Huesca).

Remarks: First attributed to the Necrolemuridae, it displays a very primitive upper dentition and a derived lower dentition without paraconid and with a very reduced trigonid (Crusafont-Pairó, 1967).

Main references: Crusafont-Pairó (1967, 1973); Szalay (1971); Crusafont-Pairó and Golpe-Posse (1968, 1973b, 1974, 1975); Antunes et al. (1997); Marigó et al. (2011c).

\section{Genus Cantius Simons, 1962 Cantius sp.}

Iberian localities: La Coma (=La Morera del Montsant 2) (Tarragona); Güell III (Huesca).

Remarks: The genus Cantius has a wide geographic distribution, including Europe (Spain and France) and North America. It has been identified in Neustrian (MP8+9) and Grauvian (MP10) sites. The material from the two Iberian localities is very scarce, so that an attribution to the species level is not possible until more material is recovered.

Main references: Antunes et al. (1997); Marigó et al. (2011c).

Tribe Anchomomyini Szalay and Delson, 1979

(sensu Godinot, 1988)

cf. Anchomomyini indet.

Iberian localities: Montblanc, Coll de l'Illa and Ulldemolins I (Tarragona).

Remarks: The attribution of material from Montblanc and Coll de l'Illa to Anchomomyini indet. by Antunes et al. (1997) cannot be confirmed based on the material currently housed at the Institut Català de Paleontologia Miquel Crusafont. Several isolated teeth from Ulldemolins I are also tentatively assigned to the tribe Anchomomyini, until a detailed study enables a more precise determination.

Main references: Antunes et al. (1997); Marigó et al. (2011c).

Anchomomyini nov.

Iberian localities: Sossís (Lleida).

Remarks: This taxon was previously thought to represent a new Anchomomys species (Marigó et al., 2011c), but further study of the available material has revealed that it displays several features distinguishing it from other anchomomyin genera (very buccolingually compressed $\mathrm{P}^{4}$, extremely reduced metacone in the $\mathrm{M}^{3}$, and the complete premetacristid closing the trigonid basin from the lingual side on the lower molars).

Main references: Marigó et al. $(2011 b, c)$.

\section{Genus Anchomomys Stehlin, 1916 Anchomomys sp.}

Iberian localities: Sant Jaume de Frontanyà 1 (Barcelona); Caenes (Salamanca).

Remarks: The genus Anchomomys is well known from several European sites (Switzerland, France, Spain), ranging in age from the Geiseltalian to the Headonian (MP13-17a, Middle-Late Eocene, 44-37 Ma). The material from Caenes, curently under study, consists of two complete and one fragmentary right upper molars, and two left mandible fragments, one showing a complete $\mathrm{P}_{4}$ and the other presenting an almost complete $\mathrm{P}_{4}$, a partial $\mathrm{M}_{1}$ and a complete $\mathrm{M}_{2}$, and both with the rest of the alveoli from the lower $\mathrm{C}$ to the $\mathrm{M}_{3}$. In addition, a few isolated teeth from Sant Jaume de Frontanyà 1 can be assigned to the genus Anchomomys, although the scarcity of material precludes a determination to the species level.

Main references: Moyà-Solà and Köhler (1992); Antunes et al. (1997); Moyà-Solà et al. (2012); Marigó et al. (2011c, 2012b).

\section{Anchomomys frontanyensis Marigó, Minwer-Barakat and Moyà-Solà, 2011a}

(Fig. 1E-F).

Geographic distribution: Exclusively known from the type locality.

Chronological range: 43-42 Ma (MP14, Robiacian, Middle Eocene).

Iberian localities: Sant Jaume de Frontanyà 3 [type locality] (Barcelona).

Remarks: The material from this locality represents the largest collection of Anchomomys material ever described, including all the permanent teeth except for the incisors. A. frontanyensis resembles A. pygmaeus from Egerkingen (Ef 372) although it has a more reduced hypocone and paraconule, its hypocone is less projected lingually, and its upper molars have a less developed anterocingulum extending further lingually. Despite sharing features with other anchomomyins, $A$. frontanyensis also shares certain characters with extinct asiadapines and extant lemurs and lorises. Moreover, the presence of A. frontanyensis in the Iberian Peninsula reveals a different lineage from that present at the same time in the rest of Europe. Phylogenetic analyses suggest that anchomomyins might be related to either asiadapines or crown strepsirrhines.

Main references: Moyà-Solà and Köhler (1993b); Antunes et al. (1997); Marigó et al. (2011a, b, c); Minwer-Barakat et al. (2011a); Roig and Moyà-Solà (2011); Moyà-Solà et al. (2012). 


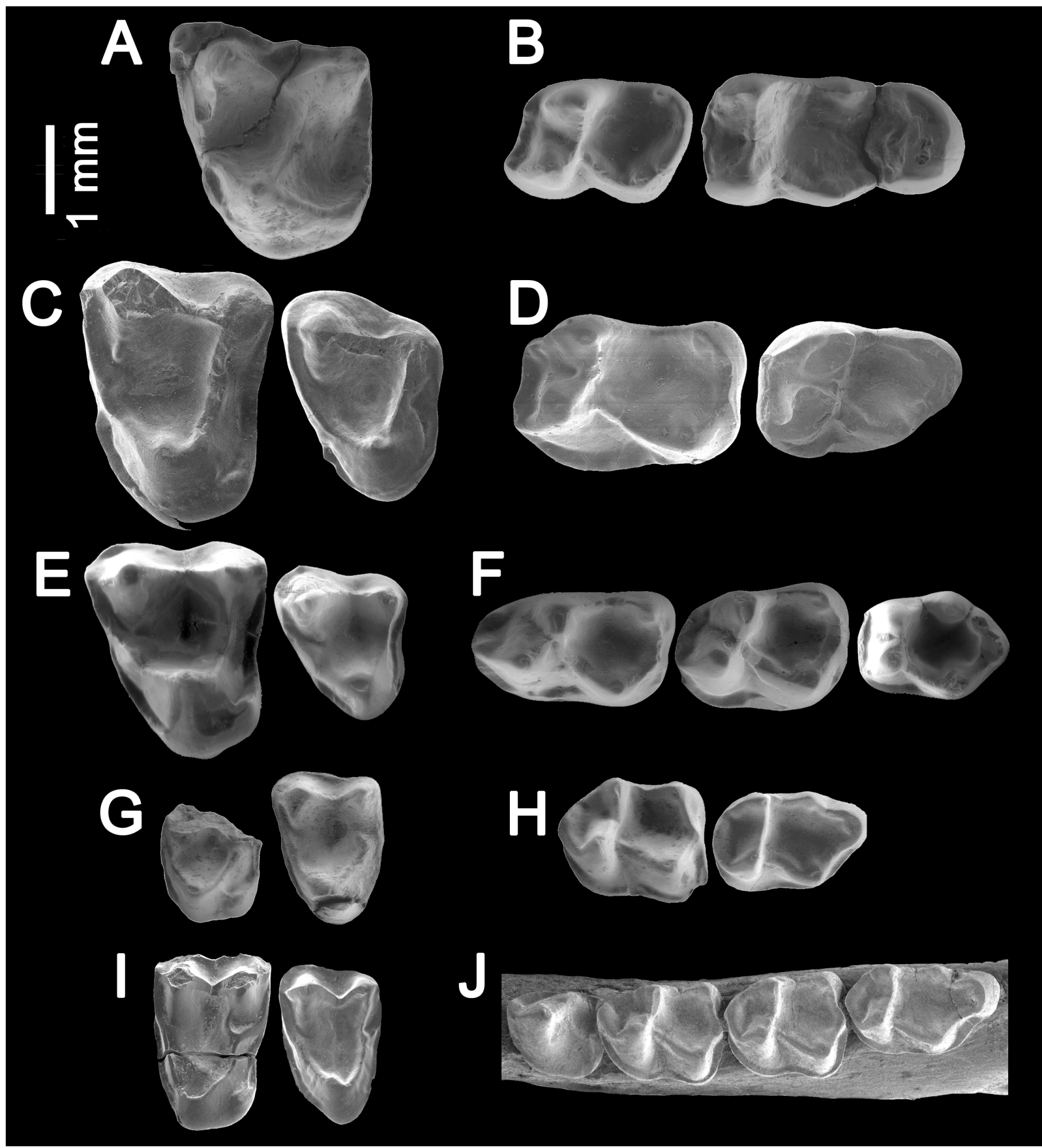

Fig. 1.- Selected dentognathic remains of fossil primates from the Iberian Paleogene. A, Left $\mathrm{M}^{1-2}$ (IPS57508) of Arcius sp. from Masia de l'Hereuet; B, Right $\mathrm{M}_{1-2}$ (IPS57510, reversed) and right $\mathrm{M}_{3}$ (IPS57511, reversed) of Arcius sp. from Masia de l'Hereuet; C, Right M $^{1-2}$ (IPS46263, reversed) and right $\mathrm{M}^{3}$ (IPS46266, reversed) of Mazateronodon endemicus from Mazaterón; D, Left $\mathrm{M}_{2}$ (IPS46232) and left $\mathrm{M}_{3}$ (IPS46234) of Mazateronodon endemicus from Mazaterón; E, Right $\mathrm{M}^{1-2}$ (IPS8429, holotype, reversed) and right $\mathrm{M}^{3}$ (IPS8423, reversed) of Anchomomys frontanyensis from Sant Jaume de Frontanyà 3; F, Left $\mathrm{M}_{1}$ (IPS8543), left $\mathrm{M}_{2}$ (IPS8487) and right $\mathrm{M}_{3}$ (IPS8447, reversed) of Anchomomys frontanyensis from Sant Jaume de Frontanyà 3; G, Right M ${ }^{1-2}$ (IPS46205, reversed) and right $\mathrm{M}^{3}$ (IPS46206, reversed) of Pseudoloris cuestai from Mazaterón; H, Right M, (IPS46195, reversed) and left $\mathrm{M}_{3}$ (IPS46196, holotype) of Pseudoloris cuestai from Mazaterón; I, Left M ${ }^{1-2}$ (IPS46335) and right M³ (IPS46342, reversed) of Pseudoloris pyrenaicus from Sant Jaume de Frontanyà 3; J, Fragment of a right mandible with $\mathrm{P}_{4}$ - $\mathrm{M}_{3}$ (IPS46297, holotype, reversed) of Pseudoloris pyrenaicus from Sant Jaume de Frontanyà 3. 
Anchomomys cf. pygmaeus (Gingerich, 1977)

Geographic distribution: Switzerland and Spain.

Chronological range: 44-42 Ma (MP13-14, Geiseltalian-

Robiacian, Middle Eocene).

Iberian localities: Santa Clara (Zamora).

Remarks: The only available material is an $\mathrm{M}_{2}$ that resembles that of $A$. cf. pygmaeus En-1 specimen from Egerkingen, first attributed to A. stehlini by Gingerich (1977), but later assigned to $A$. cf. pygmaeus by Godinot (1988).

Main references: Gingerich (1977); Godinot (1988); Peláez-Campomanes et al. (1989); Antunes et al. (1997); Marigó et al. (2011c).

Genus Mazateronodon Marigó, Minwer-Barakat and MoyàSolà, 2010

(Fig. 1C-D).

Mazateronodon endemicus Marigó, Minwer-Barakat and Moyà-Solà, 2010

Geographic distribution: Exclusively known from the type locality.

Chronological range: 42-37 Ma, MP15-16, Robiacian, Middle Eocene.

Iberian localities: Mazaterón [type locality] (Soria).

Remarks: This taxon allowed the description, for the first time, of almost all the dental elements and the anterior dentition for a member of the Anchomomyini. The material attributed to Mazateronodon endemicus is the richest Eocene primate assemblage from the Western Iberian Bioprovince. Mazateronodon differs morphologically and biometrically from all the other anchomomyins, and it is characterized by its extremely buccolingually compressed $\mathrm{P}_{3}$ and $\mathrm{P}_{4}$, with the $\mathrm{P}_{3}$ larger than the $\mathrm{P}_{4}$, its highly imbricated premolars, with overlapping crowns and buccal and lingual cingulids. Some similarities with the material assigned to Anchomomys from Caenes (Duero Basin) and Anchomomys frontanyensis (Pyrenean Basin) strongly suggest an Iberian origin of this taxon. The unique features of Mazateronodon support the idea of endemism in the Eocene faunas of the Duero Basin, and the existente of a Western Iberian Bioprovince, isolated form the rest of Europe during the Eocene due to a marine transgression that connected the Cantabric and the Mediterranean seas.

Main references: Antunes et al. (1997); Marigó et al. (2009, 2010, 2011b, c).

Family Adapidae Trouessart, 1879

Subfamily Adapinae Trouessart, 1879

Genus Leptadapis Gervais, 1876

Leptadapis priscus (Stehlin, 1916)

Geographic distribution: Switzerland and Spain.

Chronological range: 44-42 Ma (MP13-14, Geiseltalian-

Robiacian, Middle Eocene).
Iberian localities: Capella (Huesca).

Remarks: The material from Capella was the first adapiform recovered from Spain. It consists of a single mandible fragment with $\mathrm{I}_{2}-\mathrm{M}_{3}$, which was attributed to Adapis priscus by Crusafont-Pairó (1965b). Later on, Adapis priscus was transfered to Leptadapis by Szalay and Delson (1979).

Main references: Crusafont-Pairó (1958a, 1965b, 1967); Crusafont-Pairó and Golpe-Posse (1974, 1975); Antunes et al. (1997); Marigó et al. (2011c).

Leptadapis capellae (Crusafont-Pairó, 1967)

Geographic distribution: Exclusively known from the type locality.

Chronological range: 43-42 Ma (MP14, Robiacian, Middle Eocene).

Iberian localities: Capella [type locality] (Huesca).

Remarks: This species, known exclusively from the holotype (a single $\mathrm{M}^{3}$ ), was defined as Arisella capellae by Crusafont-Pairó (1965b), and then transfered to Leptadapis by Szalay (1971).

Main references: Crusafont-Pairó (1965b; 1967); Szalay (1971); Crusafont-Pairó and Golpe-Posse (1968, 1974); Antunes et al. (1997); Marigó et al. (2011c).

\section{Leptadapis magnus (Filhol, 1874)}

Geographic distribution: France, UK and Spain.

Chronological range: 40.5-34 Ma (MP16-MP18-19, Robiacian-Headonian, Middle-Late Eocene).

Iberian localities: Roc de Santa (Barcelona).

Remarks: Originally described within the genus Adapis by Filhol (1874), it was subsequently attributed to Leptadapis by Gervais (1876), which after more accurate studies was recently confirmed by Godinot and Couette (2008). The scarce material from Roc de Santa, a right maxilla with $\mathrm{P}^{3}-\mathrm{M}^{3}$ and a left mandible with a broken $\mathrm{P}_{3}$ and the $\mathrm{P}_{4}-\mathrm{M}_{2}$ series, was assigned to Adapis cf. magnus by Crusafont-Pairó and GolpePosse (1974), given its somewhat smaller size compared to the type material. Nevertheless, subsequent studies have confirmed the ascription of the material from Roc de Santa to this species (Casanovas-Cladellas, 1975; Casanovas, 1998; Antunes et al., 1997).

Main references: Crusafont-Pairó and Golpe-Posse (1974, 1975); Antunes et al. (1997); Marigó et al. (2011c).

Genus Adapis Cuvier, 1821 Adapis cf. parisiensis Cuvier, 1821

Geographic distribution: France, UK and Spain.

Chronological range: 40.5-34 Ma (MP16-19, RobiacianHeadonian, Middle-Late Eocene).

Iberian localities: Sossís (Lleida).

Remarks: The published material from Sossís consists of an upper molar (probably an $\mathrm{M}^{1}$ ) and an upper premolar 
(Crusafont-Pairó and Golpe-Posse, 1974). They were attributed to Adapis cf. parisiensis, although Antunes et al. (1997) cited them as Leptadapis cf. ruetimeyeri. Later studies, however, attributed the material again to $A$. cf. parisiensis (Casanovas, 1998), so we think that the attribution by Antunes et al. (1997) to $L$. cf. ruetimeyeri was merely a mistake. The detailed study of additional material from this locality, recovered from subsequent field campaigns and still unpublished, may increase the number of specimens ascribed to this taxon.

Main references: Crusafont-Pairó (1967); Crusafont-Pairó and Golpe-Posse (1974; 1975); Antunes et al. (1997); Casanovas (1998); Marigó et al. (2011c).

\section{Adapis sp.}

Iberian localities: Sant Jaume de Frontanyà 3 (Barcelona).

Remarks: The genus Adapis has an exclusively European geographic distribution, including France, Switzerland, UK and Spain. It is known from the Robiacian (MP14, Middle Eocene) to the Headonian (MP19, Late Eocene). The material from Sant Jaume de Frontanyà 3 consists of several isolated teeth, currently under study, that may allow a specific determination.

Main references: Moyà-Solà and Köhler (1993b); Antunes et al. (1997); Marigó et al. (2011c); Miwer-Barakat et al. (2011a).

$$
\text { cf. Adapis sp. }
$$

Iberian localities: Mazaterón (Soria).

Remarks: A mandibular fragment with the complete molar series from this locality is currently under study. It has been tentatively assigned to Adapis, although the material may be too scarce to be determined to the species level.

Main references: Antunes et al. (1997); Marigó et al. (2009, 2010, 2011c); Minwer-Barakat et al. (2012)

\section{Genus Microadapis Szalay, 1974 Microadapis sp.}

Iberian localities: Caenes (Salamanca).

Remarks: The genus Microadapis is known from several Swiss and Spanish Middle Eocene localities ranging in age from the MP13 (Geiseltalian) to the MP16 (Robiacian). The material from Caenes consists only of a single upper molar. Until more material is recovered, it is not possible to reach a species determination.

Main references: Moyà-Solà and Köhler (1992); Antunes et al. (1997); Marigó et al. (2011c).

Suborder Haplorrhini Pocock, 1918

Infraorder Tarsiiformes Gregory, 1915

Superfamily Omomyoidea Trouessart, 1879

Family Omomyidae Trouessart, 1879

Omomyidae indet.
Remarks: The material consists of two isolated molars of a very small omomyid. The detailed study of these remains, as well as further fieldwork for obtaining more material, may allow the description of a new taxon.

Main references: Antunes et al. (1997); Marigó et al. (2011c).

\section{Subfamily Microchoerinae Lydekker, 1887 Microchoerinae indet.}

Iberian localities: Zambrana (Álava).

Remarks: The material from Zambrana consists of two well-preserved right mandibular fragments with relatively complete dental series, including $\mathrm{P}_{3}-\mathrm{M}_{3}$ and $\mathrm{P}_{4}-\mathrm{M}_{3}$. The overall dental morphology and the presence of enamel wrinkling are similar to those observed in the genera Necrolemur and Microchoerus. The detailed study of this material, now under way, will lead to a more precise determination. This discovery, together with that of Pseudoloris cuestai from Mazaterón (Minwer-Barakat et al., 2012), constitutes the first record of microchoerines in the Western Iberian Bioprovince.

Main references: Minwer-Barakat et al. (2011b).

Genus Microchoerus Wood, 1844

Microchoerus erinaceus Wood, 1844

Geographic distribution: UK, France, Switzerland and Spain. Chronological range: 40.5-35 Ma (MP16-18, RobiacianHeadonian, Middle-Late Eocene).

Iberian localities: Sossís (Lleida).

Remarks: This large-sized microchoerine from Sossís was first reported by Crusafont-Pairó (1965b), and subsequently Crusafont-Pairó (1967) briefly described a quite complete sample of this species, including isolated teeth, some dental series and several fragments of mandibles and maxillae. This author further figured a lower dental series including $\mathrm{P}_{3}-\mathrm{M}_{3}$, and an upper dental series with $\mathrm{M}^{1}$ and $\mathrm{M}^{2}$. Crusafont-Pairó (1967) and Crusafont-Pairó and Golpe-Posse (1974) referred these remains to Necrolemur erinaceus, but later works (Antunes et al., 1997; Casanovas, 1998) employed the correct denomination, i.e. Microchoerus erinaceus. Subsequent field work led to the recovery of more abundant material, which is still unpublished. A preliminary observation of this material reveals some biometric and morphologic differences relative to the material from the type locality (Hordle Cliff Crocodile Bed, Hampshire, UK). However, until a detailed study of the population from Sossís is carried out, we prefer mantaining the attribution to $M$. erinaceus.

Main references: Crusafont-Pairó (1965b, 1967); Crusafont-Pairó and Golpe-Posse (1974); Antunes et al. (1997); Casanovas (1998); Marigó et al. (2011c).

\section{Microchoerus ornatus Stehlin, 1916}

Iberian localities: Pontils 38 (Barcelona).

Geographic distribution: Switzerland and Spain. 
Chronological range: 35-34 Ma (MP19, Headonian, Late Eocene).

Iberian localities: Sant Cugat de Gavadons (=Collsuspina) (Barcelona).

Remarks: Only known from upper teeth, Microchoerus ornatus has been considered doubtfully distinct from $M$. edwardsi (Hooker, 1986; Gunnell and Rose, 2002). In the Iberian Peninsula, the only material assigned to this species is a fragment of maxilla with $\mathrm{P}^{4}-\mathrm{M}^{1}$ from Sant Cugat de Gavadons, which according to Crusafont-Pairó (1967) and Crusafont-Pairó and Golpe-Posse (1974), shares strong similarities with the material from the type locality of M. ornatus (Mormont-Entreroches, Switzerland).

Main references: Crusafont-Pairó (1967); Crusafont-Pairó and Golpe-Posse (1974); Golpe-Posse (1982c); Marigó et al. (2011c).

\section{Microchoerus sp.}

Iberian localities: Aguatón (Teruel).

Remarks: The genus Microchoerus is well represented in Central and Western Europe (Spain, France, UK, Switzerland and Germany), in localities that range in age from the Robiacian (MP16, Middle Eocene) to the Suevian (MP21, Early Oligocene). In the Iberian Peninsula, besides the above-mentioned remains ascribed to $M$. erinaceus and M. ornatus, a single $\mathrm{M}_{1}$ from the site of Aguatón was described by PeláezCampomanes (2000). This tooth, similar in size to those of M. erinaceus, shows morphological and/or metrical differences with all the previously described species of Microchoerus (except for M. ornatus, only known from upper teeth). However, due to the scarcity of material, the author preferred not to describe a new species until more material is available.

Main references: Peláez-Campomanes (2000).

Genus Pseudoloris Stehlin, 1916 Pseudoloris isabenae (Crusafont-Pairó, 1967)

Geographic distribution: Spain and France.

Chronological range: 44-43 Ma (MP13-14, GeiseltalianRobiacian, Middle Eocene).

Iberian localities: Capella [type locality] (Huesca).

Remarks: This species was originally ascribed to the genus Pivetonia by Crusafont-Pairó (1967); however, most authors have considered Pivetonia to be a junior subjective synonym of Pseudoloris (Szalay, 1971; Godinot, 1983; Gunnell and Rose, 2002; Minwer-Barakat et al., 2010, 2012). The only available material from Capella is a mandible fragment with $\mathrm{P}_{3}-\mathrm{M}_{2}$. It differs from other species of Pseudoloris found in the Iberian Peninsula in the smaller size and the presence of a well-individualized tubercular paraconid in the lower molars.

Main references: Crusafont-Pairó (1965b, 1967); Szalay (1971); Crusafont-Pairó and Golpe-Posse (1968, 1974); Antunes et al. (1997); Minwer-Barakat et al. (2010, 2012); Marigó et al. (2011c).

\author{
Pseudoloris pyrenaicus Minwer-Barakat, Marigó \\ and Moyà-Solà, 2010
}

(Fig. 1I-J)

Geographic distribution: Exclusively known from the type locality.

Chronological range: 43-42 Ma (MP14, Robiacian, Middle Eocene).

Iberian localities: Sant Jaume de Frontanyà 3 [type locality] (Barcelona).

Remarks: The material of this species represents the most complete sample of the genus Pseudoloris published from the Iberian Peninsula, having enabled the description of almost all the dental elements, including upper and lower incisors, undescribed for most species of this genus. P. pyrenaicus can be distinguished from the other Pseudoloris species by its medium size and by several morphological features, such as the absence of a distinct paraconid and the thickened paracristid in the lower molars, the large hypoconulid in the $M_{3}$, the small hypocone and paraconule in the $\mathrm{M}^{1}$ and $\mathrm{M}^{2}$, and the absence of these two cusps in the $\mathrm{M}^{3}$. This species, an intermediate form between $P$. isabenae and $P$. parvulus, forms part of an anagenetic lineage that evolved in Europe during the Middle-Late Eocene.

Main references: Moyà-Solà and Köhler (1993b); Antunes et al. (1997); Minwer-Barakat et al. (2010, 2011a); Marigó et al. $(2011 \mathrm{~b}, \mathrm{c})$.

\section{Pseudoloris cuestai Minwer-Barakat, Marigó and Moyà-Solà, 2012}

(Fig. 1G-H).

Geographic distribution: Exclusively known from the type locality.

Chronological range: 42-37 Ma (MP15-16, Robiacian, Middle Eocene).

Iberian localities: Mazaterón [type locality] (Soria).

Remarks: P. cuestai represents, together with the undetermined Microchoerinae from Zambrana, the only record of this subfamily in the Western Iberian Bioprovince. It can be distinguished from the other Pseudoloris species by its medium size, high and thick paracristid and absence of a distinct paraconid in the lower molars, large hypoconulid in the $\mathrm{M}_{3}$, well-developed protocone in the $\mathrm{P}^{3}$ and $\mathrm{P}^{4}$, small hypocone in the upper molars, and especially for its particular lower incisors, with a large, buccolingually enlarged crown and a thick root. It shows several similarities with $P$. pyrenaicus and $P$. parvulus, the closest species in age and geographic situation. Nevertheless, there are also clear differences with those species, especially in the anterior dentition. The peculiar morphology of the $\mathrm{I}_{1}$, together with the short roots of the lower canine and $\mathrm{P}_{3}$, suggests an anterior dentition that differs from that of $P$. pyrenaicus and $P$. parvulus, perhaps in relation to dietary differences. 
Main references: Antunes et al. (1997); Marigó et al. (2009, 2011b, c); Minwer-Barakat et al. (2010, 2012).

\section{Pseudoloris parvulus (Filhol, 1890)}

Geographic distribution: France and Spain.

Chronological range: 40.5-36.5 Ma (MP16-17, Robiacian-

Headonian, Middle-Late Eocene).

Iberian localities: Sossís (Lleida).

Remarks: The material described by Crusafont-Pairó (1965b, 1967) and Crusafont-Pairó and Golpe-Posse (1974) consists of a single mandibular fragment with $\mathrm{P}_{4}-\mathrm{M}_{3}$. However, there is additional, still unpublished material of $P$. parvulus from Sossís housed at the Institut Català de Paleontologia Miquel Crusafont. Among other features, P. parvulus from Sossís shows a low and sharp paracristid in the lower molars, a compressed hypoconulid in the $\mathrm{M}_{3}$, and the hypocone of the upper molars more developed than $P$. pyrenaicus and $P$. cuestai. This species has been identified in several Robiacian and Headonian French sites, but the only mention in the Iberian Peninsula corresponds to Sossís.

Main references: Crusafont-Pairó (1965b, 1967); Crusafont-Pairó and Golpe-Posse (1974); Antunes et al. (1997); Minwer-Barakat et al. (2010); Marigó et al. (2011c).

\section{Pseudoloris reguanti Crusafont-Pairó, 1967 (nomen dubium)}

Geographic distribution: Exclusively known from the type locality.

Chronological range: 35-34 Ma (MP19, Headonian, Late Eocene).

Iberian localities: Sant Cugat de Gavadons (=Collsuspina) [type locality] (Barcelona).

Remarks: This species was described by Crusafont-Pairó (1967) on the basis of a single isolated lower molar from Sant Cugat de Gavadons, larger than those of $P$. parvulus, and with a paracristid instead of a tubercular paraconid. SchmidtKittler (1977) considered this species as a nomen nudum because of the lack of illustrations of the holotype; however, according to the International Code of Zoological Nomenclature, this reason does not invalidate the species name from a nomenclatural viewpoint. Unfortunately, as pointed out by Köhler and Moyà-Solà (1999), this specimen was lost in the 1970s. Therefore, until more material is available, the taxonomic validity of this nominal taxon cannot be further evaluated, so we consider it a nomen dubium.

Main references: Crusafont-Pairó (1967); Crusafont-Pairó and Golpe-Posse (1974); Schmidt-Kittler (1977); Golpe-Posse (1982c); Köhler and Moyà-Solà (1999); Minwer-Barakat et al. (2010, 2012); Marigó et al. (2011c).

Pseudoloris godinoti Köhler and Moyà-Solà, 1999

Geographic distribution: Exclusively known from Spain.
Chronological range: 34-31 Ma (MP21-22, Suevian, Early

Oligocene).

Iberian localities: Fonollosa 13 [type locality] and Santpedor 2 (Barcelona).

Remarks: P. godinoti is known only by six complete teeth (including an upper series of $\mathrm{P}^{2}-\mathrm{M}^{1}$ designated as the holotype) and two fragments, recovered from the Oligocene localities of Santpedor-2 and Fonollosa-13. The $\mathrm{M}^{1}$ has a reduced trigon basin, a large and well-individualized hypocone and a prominent metastyle, and the $\mathrm{M}_{1}$ shows a distinct paraconid. This is the only record of the genus Pseudoloris after the Eocene-Oligocene boundary.

Main references: Köhler and Moyà-Solà (1999); MinwerBarakat et al. (2010, 2012); Marigó et al. (2011c).

\section{Pseudoloris sp.}

Iberian localities: Casa Ramón (Huesca).

Remarks: The genus Pseudoloris is known from several sites in France, UK, Germany and Spain, ranging in age from the Geiseltalian (Middle Eocene, MP11-12) to the Suevian (Early Oligocene, MP22). The Geiseltalian Spanish site of Casa Ramón (Peláez-Campomanes, 1995) has yielded two fragments of $\mathrm{M}^{1}$ and $\mathrm{M}^{3}$ and a complete $\mathrm{M}^{2}$ ascribed to Pseudoloris sp., being similar in size but morphologically different compared to those of $P$. parvulus. The $\mathrm{M}^{2}$ from Casa Ramón shows poorly-developed metaconule crests, and small paraconule and metaconule. The scarce material from this Spanish site, assigned to the MP11 or MP12, represents the earliest record of the genus Pseudoloris.

Main references: Peláez-Campomanes (1995); Antunes et al. (1997); Minwer-Barakat et al. (2010, 2012); Marigó et al. (2011c).

Genus Necrolemur Filhol, 1873

Necrolemur antiquus Filhol, 1873

Geographic distribution: France and Spain.

Chronological range: 37-36.5 Ma (MP17-20, Headonian, Late Eocene).

Iberian localities: Roc de Santa (Barcelona).

Remarks: Known from several Late Eocene sites from France, $N$. antiquus has only been mentioned in the Iberian Peninsula from the locality of Roc de Santa. The material consists of a single, heavily worn $\mathrm{M}_{3}$ described by Casanovas-Cladellas (1975). The scarcity and poor preservation of the material makes such specific assignation doubtful, but until a more detailed study is carried out, we prefer maintaining the above-mentioned determination.

Main references: Casanovas-Cladellas (1975); Antunes et al. (1997); Casanovas (1998); Marigó et al. (2011c).

\section{Necrolemur sp.}

Iberian localities: Sant Jaume de Frontanyà 1 and 2, and Sant Cugat de Gavadons (=Collsuspina) (Barcelona). 
Remarks: The genus Necrolemur is known from several French, Swiss and Spanish sites ranging in age from the Geiseltalian (MP13, Middle Eocene) to the Headonian (MP20, Late Eocene). There are two citations of the genus Necrolemur without specific determination in the Iberian Peninsula. On the one hand, Crusafont-Pairó (1967) and Crusafont-Pairó and Golpe-Posse (1974) assigned to this genus a single, large and very worn $\mathrm{M}^{2}$ from Sant Cugat de Gavadons. There is no available illustration of this specimen, whose attribution cannot be confirmed based on the material from the Institut Català de Paleontologia Miquel Crusafont. The generic ascription of this tooth is therefore doubtful, since another large-sized microchoerine, ascribed by the same authors to Microchoerus ornatus, was identified in this locality; it seems probable that these remains belong to the same taxon. On the other hand, Necrolemur sp. has also been cited from the Robiacian levels of Sant Jaume de Frontanyà 1 and 2 (Busquets et al., 1992; Antunes et al., 1997). The material consists of several isolated teeth and a mandible with $\mathrm{P}_{4}-\mathrm{M}_{3}$ of a small microchoerine. A detailed study, currently under way, will allow a more precise determination of this material.

Main references: Crusafont-Pairó (1967); Crusafont-Pairó and Golpe-Posse (1974); Golpe-Posse (1982c); Busquets et al. (1992); Antunes et al. (1997); Marigó et al. (2011c).

Infraorder Simiiformes Hoffstetter, 1974 (=Anthropoidea Mivart, 1864)

Remarks: Hoffstetter (1974) proposed Simiiformes as a replacement name for Anthropoidea, apparently on the basis of insufficient grounds (Delson, 1977), although it has several advantages such as avoiding the standard superfamily ending in -oidea for a taxon above the family-group level (see Delson, 1977, and Hoffstetter, 1982, for further details). Both Simiiformes and Anthropoidea have been recently used by several authors with the same meaning (e.g., Groves, 2001 and Fleagle, 1999, respectively; but see Rosenberger, 2006, for a different option), and hence are considered synonyms here. The International Code of Zoological Nomenclature does not regulate these taxonomic ranks, and hence the use of one or the other remains arbitrary.

Parvorder Catarrhini É. Geoffroy Saint-Hilaire, 1812 Superfamily Pliopithecoidea Zapfe, 1960

Family Pliopithecidae Zapfe, 1960

Subfamily incertae sedis

Pliopithecidae indet.

Iberian localities: Abocador de Can Mata/C3-B2.

Remarks: The oldest record of Iberian pliopithecids corresponds to an isolated $\mathrm{M}^{3}$ from $\mathrm{ACM} / \mathrm{C} 3-\mathrm{B} 2$ (Alba et al., 2012a), which has an estimated age of $12.0 \mathrm{Ma}$ (MN7, late Aragonian, Middle Miocene). This tooth displays a very peculiar occlusal morphology, which enables it to be distinguished from all other pliopithecids for which this dental posi- tion is known (including Barberapithecus, see below, but not Pliopithecus canmatensis). It is also possible that this primate tooth does not belong to the Pliopithecidae but to some other group of stem catarrhines previously not recorded in Eurasia. However, on paleobiogeographic grounds, an attribution to the Pliopithecidae was favored by Alba et al. (2012a).

Main references: Alba et al. (2012a).

$$
\begin{gathered}
\text { Subfamily Pliopithecinae Zapfe, } 1960 \\
\text { Genus Pliopithecus Gervais, } 1849 \\
\text { Pliopithecus canmatensis Alba et al., 2010d }
\end{gathered}
$$

(Fig. 2A)

Geographic distribution: Restricted to the Vallès-Penedès Basin (Barcelona).

Chronological range: $11.8-11.7 \mathrm{Ma}(\mathrm{MN} 8$, late Aragonian, Middle Miocene).

Iberian localities: Abocador de Can Mata localities ACM/ $\mathrm{C} 5-\mathrm{C} 3, \mathrm{ACM} / \mathrm{C} 4-\mathrm{Cb}, \mathrm{ACM} / \mathrm{C} 5-\mathrm{C} 2, \mathrm{ACM} / \mathrm{C} 5-\mathrm{A} 8$ and $\mathrm{ACM} /$ C4-A1.

Remarks: This species is known from several mandibles, dentognathic fragments and isolated teeth that overall record most of the permanent dentition as well as the $\mathrm{dP}_{4}$. These remains correspond to at least 8 individuals from 5 different localities of the Abocador de Can Mata series; although an age range of 11.7-11.6 was originally reported for this species (Alba et al., 2010d), subsequent analyses have redated it to 11.8-11.7 Ma (Alba et al., 2012a). The pliopithecine morphology and the small size of the dental remains from these several localities from Abocador de Can Mata is most similar to that of Pliopithecus antiquus from the French localities of Sansan (MN6) and La Grive (MN7+8), but dental proportions as well as several occlusal details (less peripheral position of the protoconid and more median position of the hypoconulid, more mesial position of the buccal cuspids compared to the lingual ones, narrower but distinct mesial fovea, higher trigonid, and more extensive buccal cingulid) justify a taxonomic distinction at the species level for the ACM material (Alba et al., 2010d).

Main references: Alba et al. (2010c, d, 2012a).

\section{Pliopithecus sp.}

Iberian localities: Sant Quirze (Barcelona).

Remarks: Pliopithecids are recorded in the late Aragonian (MN8, ca. 11.8-11.2 Ma) locality of Sant Quirze by an isolated $\mathrm{M}^{2}$ described by Harrison et al. (2002). Both in size and morphology, this tooth is consistent with an attribution to Pliopithecus platyodon, otherwise unknown from the Iberian Peninsula. However, the scarcity of the available material precludes evaluating whether it might represent a different species. In any case, an attribution to $P$. canmantensis can be easily discarded on the larger size of the Sant Quirze molar.

Main references: Harrison et al. (2002). 


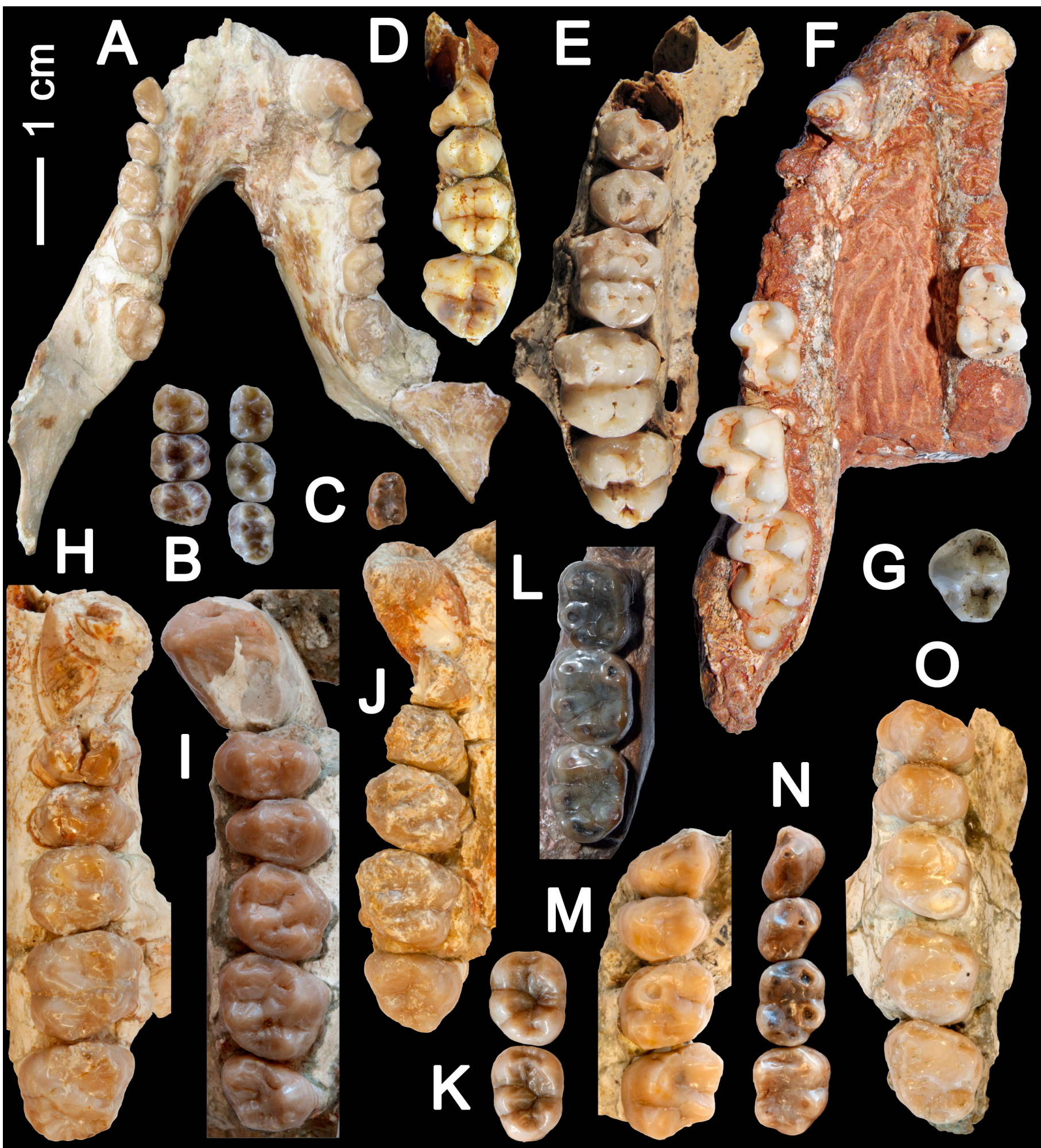

Fig. 2.- Selected dentognathic remains of fossil primates from the Iberian Neogene and Quaternary. $\mathbf{A}_{\text {, }} \mathrm{Mandible}$ with left $\mathrm{P}_{3}$ - $\mathrm{M}_{3}$ and right $\mathrm{C}_{1}-$ $\mathrm{M}_{3}$ (IPS35036, holotype) of Pliopithecus canmatensis from ACM/C4-A1; B, Right $\mathrm{M}^{1}-\mathrm{M}^{3}$ and left $\mathrm{M}_{1}-\mathrm{M}_{3}$ (IPS1724, holotype; $\mathrm{M}_{2}$ reversed) of Barberapithecus canmatensis from Castell de Barberà; C, Right $\mathrm{dP}_{4}$ (IPS35565) of cf. Anapithecini indet. from Can Sant Feliu; D, Right $\mathrm{P}^{3}-\mathrm{M}^{2}$ (EVT24036) of Macaca sylvanus cf. florentina from Vallparadís Estació; E, Right $\mathrm{P}^{3}-\mathrm{M}^{3}$ (Q05-Ec-88) of Macaca sylvanus florentina from Quibas;

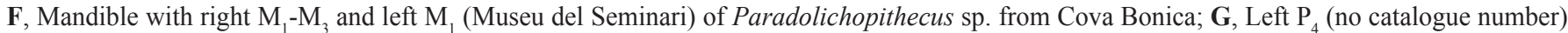
of Theropithecus oswaldi from Cueva Victoria; H, Left $\mathrm{C}^{1}-\mathrm{M}^{3}$ (IPS35026) of Dryopithecus fontani from ACM/C3-Ae; I, Right $\mathrm{C}^{1}-\mathrm{M}^{3}$ (IPS21350, holotype) of Pierolapithecus catalaunicus from ACM/BCV1; J, Right $\mathrm{C}^{1}-\mathrm{M}^{3}$ (IPS43000, holotype) of Anoiapithecus brevirostris from ACM/C3-Aj; K, Left $\mathrm{M}_{2}-\mathrm{M}_{3}$ (IPS1826+IPS1827, holotype) of "Sivapithecus" occidentalis (nomen dubium) from Can Vila; L, Mandible with left $\mathbf{M}_{1}-\mathrm{M}_{3}$ (Museu del Seminari) of Hispanopithecus crusafonti from Teuleria del Firal; M, Left P3 $-\mathrm{M}^{2}$ (IPS1798, holotype) of Hispanopithecus crusafonti from Can Poncic 1; N, Right $\mathrm{P}_{3}-\mathrm{M}_{2}$ (IPS1803, holotype) of Hispanopithecus laietanus from La Tarumba 1; O, Right $\mathrm{P}^{3}-\mathrm{M}^{3}$ (IPS18000.5) of Hispanopithecus laietanus from Can Llobateres 2. 
Subfamily Crouzeliinae Ginsburg and Mein, 1980

(Fig. 2B)

Tribe Anapithecini Alba and Moyà-Solà, 2012a

Genus Barberapithecus Alba and Moyà-Solà, 2012a

Barberapithecus huerzeleri Alba and Moyà-Solà, 2012a

Geographic distribution: Exclusively known from the type locality.

Chronological range: $11.2-10.5 \mathrm{Ma}$ (MN8 or MN9, late Aragonian or early Vallesian, Middle or Late Miocene).

Iberian localities: Castell de Barberà [type locality] (Barcelona).

Remarks: This taxon is only known from isolated dental remains recovered at the locality of Castell de Barberà, initially attributed to the Aragonian, but currently attributable to the latest Aragonian or, most likely, the earliest Vallesian. The find was initially reported more than three decades ago (Crusafont-Pairó, 1978). Most of the remains, including upper and lower teeth, correspond to a single, female adult individual. They were partly described and initially attributed to Pliopithecus sp. by Crusafont-Pairó and Golpe-Posse (1981), who nevertheless noted dental similarities with Plesiopliopithecus lockeri, currently attributed to the Crouzeliini. These authors noted that this material was likely to represent a new pliopithecid taxon, but refrained from formally erecting it. Later, Ginsburg (1986) attributed the Castell de Barberà remains to Crouzeliinae nov., but subsequently the taxon was considered a pliopithecine similar or attributable to Pliopithecus antiquus by several authors (Moyà Solà et al., 1990; Andrews et al., 1996; Harrison et al., 2002). Both Begun (2002a) and Alba et al. (2010d) considered it to be a new pliopithecid taxon, and most recently Alba and Moyà-Solà (2012a) erected a new genus and species for it within the Crouzeliinae. Besides the holotype individual, an isolated $\mathrm{P}_{3}$ and male $\mathrm{C}^{1}$ from the type locality are also attributed to this taxon (Alba and Moyà-Solà et al., 2012a). The latter was formerly considered a female upper canine of the hominoid Hispanopithecus laietanus (Harrison, 1991; Golpe Posse, 1993), but on morphological grounds it is best attributable to the Pliopithecidae (Begun, 2002a; Alba et al., 2010d; Alba and Moyà-Solà, 2012a). Like crouzeliins, Barberapithecus is characterized by buccolingually-compressed cusps, welldeveloped and sharp crests, and large and well-defined occlusal foveae. Its dental morphology, however, might have evolved from a pliopithecine ancestor similar to Pliopithecus canmatensis, which leaves open the possibility that, as currently conceived, the crouzeliines are polyphyletic (Alba and Moyà-Solà, 2012a).

Main references: Crusafont-Pairó (1978); Crusafont-Pairó and Golpe-Posse (1981, 1982); Moyà Solà et al. (1990); Andrews et al. (1996); Begun (2002a); Alba and Moyà-Solà (2012a); Alba et al. (2012a).
Genus Egarapithecus Moyà-Solà, Köhler and Alba, 2001

Egarapithecus narcisoi Moyà-Solà, Köhler and Alba, 2001

Geographic distribution: Exclusively known from the type locality.

Chronological range: 9.0-8.9 Ma (MN10, Vallesian, Late Miocene).

Iberian localities: Torrent de Febulines [type locality] (Barcelona).

Remarks: This taxon is known on the basis of a fragmentary mandible with right $\mathrm{P}_{3}-\mathrm{M}_{3}$ and left $\mathrm{P}_{3}-\mathrm{M}_{2}$ (holotype), as well as an isolated $\mathrm{P}^{3}$ probably from the same individual. This material was initially published by Golpe-Posse (1982b), who attributed it to Pliopithecus sp. in spite of noting several differential features that, according to her, might justify the erection of a new taxon. This was confirmed by Moyà Solà et al. (1990) and Andrews et al. (1996), although the new genus and species were not erected until Moyà-Solà et al. (2001) described it and attributed it to the Crouzeliinae. Subsequently, Begun (2002a) considered it to be a Pliopithecinae, but this has been subsequently dismissed by other authors (Harrison et al., 2002; Alba et al., 2010d; Alba and Moyà-Solà, 2012a).

Main references: Golpe Posse (1982b); Moyà-Solà et al. (1990, 2001); Andrews et al. (1996); Begun (2002a); Alba et al. (2010c).

\section{cf. Anapithecini indet.}

(Fig. 2C)

Iberian localities: Can Sant Feliu (=Can Feliu, Barcelona). Remarks: Crouzeliine affinities were noted by several authors (Moyà Solà et al., 1990; Andrews et al., 1996) for the isolated $\mathrm{dP}_{4}$ from the late Aragonian (MN8, ca. 11.8-11.2 Ma) locality of Can Sant Feliu, initially mistaken for an $\mathrm{M}_{3}$ (Crusafont-Pairó and Golpe-Posse, 1981). Begun (2002a) suggested that it might correspond to a larger individual of the same taxon represented at Castell de Barberà (currently, Barberapithecus huerzeleri), but given the presence of other pliopithecids (Pliopithecus canmatensis) during the late Aragonian in the same basin, most recently Alba and Moyà-Solà (2012a) refrained from providing a formal taxonomic attribution.

Main references: Crusafont-Pairó and Golpe-Posse (1981, 1982); Moyà Solà et al. (1990); Begun (2002a); Harrison et al. (2002); Alba and Moyà-Solà (2012a).

\section{Superfamily Cercopithecoidea Gray, 1821 \\ Family Cercopithecidae Gray, 1821 \\ Subfamily Cercopithecinae Gray, 1821 \\ Tribe Papionini Burnett, 1828 \\ Subtribe Macacina Owen, 1843 \\ Genus Macaca Lacépède, 1799 Macaca sp.}

Iberian localities: Almenara-Casablanca M (Castellon); Orrios 7 (Teruel); Sima del Elefante TE9 (Burgos); Ambrona (Soria). 
Remarks: The genus Macaca is first recorded in Europe in the latest Miocene locality of Almenara-Casablanca M (Köhler et al., 2000), after which it is known across the continent throughout the Pliocene and Pleistocene. Although there is consensus that fossil European macaques belong to the Macaca sylvanus lineage (Szalay and Delson, 1979; Alba et al., 2011c), of African origin, the scarce material from Almenara-Casablanca $\mathrm{M}$ does not enable an attribution to the species level. All other Iberian citations of Macaca sp. are most likely attributable to $M$. sylvanus, since this is the only fossil European macaque species recognized besides the endemic M. majori from Sardinia.

Main references: Aguirre and Fuentes (1969); Delson (1974); Szalay and Delson (1979); Delson (1980); Ardito and Mottura (1987); Mein et al. (1990); Moyà Solà et al. (1990); Köhler et al. (2000); Carbonell et al. (2008).

\section{Macaca sylvanus (Linnaeus, 1758)}

Geographic distribution: W. Eurasia and N. Africa.

Chronological range: Pliocene and Pleistocene.

Remarks: This species, the Barbary macaque, currently presents a disjunct distribution in Algeria and Morocco, and is also represented by the Gibraltar population, which has an anthropocorous origin (Fooden, 2007). This species was also widely distributed throughout the Plio-Pleistocene in Western Eurasia, where three distinct subspecies are customarily recognized (Szalay and Delson, 1979; Delson, 1980): M. s. pr$i s c a$, from the earlier Pliocene; $M$. s. florentina, from the late Pliocene to the early Pleistocene; and M. s. pliocena, from the Middle and perhaps Late Pleistocene.

\section{Macaca sylvanus ssp.}

Iberian localities: Cova Negra (Valencia); Cueva Negra del Estrecho del Quípar (Murcia); Solana del Zamborino (Granada); Galeria Pesada - Gruta da Aroeira (Ribatejo); Canal Negre I (Barcelona).

Remarks: With the exception of Solana del Zamborino (Martín Penela, 1983, 1988), the material from the abovementioned localities has not been described in detail, and the published citations did not include an attribution to the species level except for Guillén-Castejón (2010; see below). On chronological grounds, the macaque remains from the Middle Pleistocene localities of Cueva Negra, Solana del Zamborino and Gruta da Aroeira probably belong to M. s. pliocena. The remains from Canal Negre I, of uncertain age, have been attributed to both M. s. florentina and Macaca cf. sylvanus prisca by Guillén-Castejón (2010), mainly on the basis of size. However, size does not seem to be a reliable criterion for distinguishing among the several extinct subspecies of $M$. sylvanus (Rook et al., 2001), and given that no detailed description or measurements are provided by Guillén-Castejón (2010), the remains from Canal Negre are best left unassigned at the subspecies level.
Main references: Pérez Ripoll (1977); Martín Penela (1983, 1988); Ardito and Mottura (1987); Trinkaus et al. (2003); Walker et al. (2010).

\section{Macaca sylvanus florentina (Cocchi, 1872)}

(Fig. 2E)

Geographic distribution: Southern and Central Europe. Chronological range: Late Pliocene to Early Pleistocene. Iberian localities: Quibas (Murcia).

Remarks: The sample from the late Early Pleistocene site of Quibas (ca. 1.3-1.0 Ma) includes dentognathic remains, isolated teeth and some postcranial bone fragments (Alba et al., 2010c). Dental morphometric comparisons indicate that this sample is morphologically similar to M. s. florentina from the type locality (Upper Valdarno, Italy), further reinforcing the view that this subspecies is morphologically distinct from the extant nominotypical subspecies, by displaying on average absolutely longer upper molars, relatively wider upper molars, longer $\mathrm{M}^{3}$ compared to the $\mathrm{M}^{2}$, absolutely longer $\mathrm{M}_{1}$ and $\mathrm{M}_{3}$, and relatively narrower $\mathrm{M}_{3}$ (Alba et al., 2011c).

Main references: Montoya et al. (1999, 2001); Alba et al. (2011c).

\section{Macaca sylvanus cf. florentina (Cocchi, 1872)}

(Fig. 2D)

Iberian localities: Cal Guardiola D7, Vallparadís Estació EVT7 and EVT10, and Canal Negre I (Barcelona), and maybe La Puebla de Valverde (Teruel).

Remarks: Although the macaque dentognathic remains from the Vallparadís Section (Cal Guardiola and Vallparadís Estació, ca. 1.0-0.78 Ma) differ metrically from the extant, nominotypical subspecies, its taxonomic attribution will remain tentative until the taxonomic distinction between $M$. s. florentina and the Middle Pleistocene $M$. s. pliocena is further clarified (Alba et al., 2008). The specimens from Canal Negre, previously attributed to $M$. s. florentina by GuillénCastejón (2010), have an uncertain age, and a more detailed morphometric study would be required in order to more conclusively ascertain its taxonomic attribution to this subspecies. $\mathrm{A} \mathrm{dP}_{4}$ from the Early Pleistocene locality (Middle Villafranchian, MN17) of La Puebla de Valverde, initially attributed to Macaca sp. (Heintz et al., 1971), might belong to this taxon, although subsequently Moyà Solà et al. (1990) attributed it to Paradolichopithecus sp.

Main references: Heintz et al. (1971); Alba et al. (2008, 2010c); Madurell-Malapeira et al. (2010); Guillén-Castejón (2010).

\section{Macaca sylvanus cf. pliocena Owen, 1846}

Geographic distribution: Europe, Caucasus and Israel. Chronological range: Late Pleistocene.

Iberian localities: Lezetxiki II (Guipúzcoa). 
Remarks: The mandible from Lezetxiki was tentatively attributed to M. s. pliocena by Castaños et al. (2011) merely on chronological grounds.

Main references: Castaños et al. (2011).

Genus Paradolicopithecus Necrasov, Samson and Radulesco, 1961 cf. Paradolichopithecus sp.

Iberian localities: Almenara-Casablanca 1 (Castellón).

Remarks: A fragmentary incisor from this Early Pleistocene locality (ca. 1.8 Ma) was tentatively assigned to the genus Paradolichopithecus by Moyà Solà et al. (1990). Additional dental material would be required to discount an alternative attribution to the genus Macaca.

Main references: Moyà Solà et al. (1990).

\section{Paradolichopithecus sp.}

(Fig. 2F)

Iberian localities: Moreda 1a (Granada) and Cova Bonica (Barcelona).

Remarks: The Late Pliocene remains from Moreda 1a (3.53.2 Ma) and Cova Bonica (3.2-2.6 Ma) represent de oldest records of this genus in the Iberian Peninsula. According to Moyà Solà et al. (1990), they may correspond to a different species than $P$. arvernensis. Additional studies, however, are required in order to clarify the taxonomic status of these remains. In the past, several authors also cited the presence of Macaca at Cova Bonica (e.g., Delson, 1971; Crusafont-Pairó and Golpe-Posse, 1974, 1984), whereas, according to Moyà Solà et al. (1990), only Paradolichopithecus is recorded there. The detailed study of the material from Moreda and Cova Bonica, currently in progress, will enable a decision as to whether Macaca is present in either of these localities and hopefully also provide a determination of the Paradolichopithecus remains to the species level.

Main references: Delson (1971); Crusafont-Pairó and Golpe-Posse (1984); Moyà Solà et al. (1990); Alba et al. (2010c).

\section{Paradolichopithecus cf. arvernensis Depéret, 1929}

Geographic distribution: Europe and Central Asia.

Chronological range: Late Pliocene to Early Pleistocene (Middle Villafranchian, MN17).

Iberian localities: La Puebla de Valverde (Teruel); Canal Negre I (Barcelona).

Remarks: The Paradolichopithecus material from La Puebla de Valverde was attributed to $P$. cf. arvernensis by Aguirre and Soto (1978). We provisionally maintain such an attribution here, although noting that the species attribution might be further refined after the study of the Paradolichopithecus remains from Moreda 1a and Cova Bonica, currently under study (see comments above). Several isolated dental remains from Canal Negre, of uncertain age, have been also attributed to P. arvernensis by Guillén-Castejón (2010), but given the lack of a detailed description and uncertainties in the attribution of other Iberian Paradolichopithecus remains, the teeth from this locality are only tentatively attributed to that species here.

Main references: Heinz et al. (1971); Aguirre and Soto (1974, 1978); Ardito and Mottura (1987); Moyà Solà et al. (1990); Guillén-Castejón (2010).

Subtribe Papionina Burnett, 1828

Genus Theropithecus I. Geoffroy Saint-Hilaire, 1843

Subgenus Theropithecus I. Geoffroy Saint-Hilaire, 1843

Theropithecus (Theropithecus) oswaldi Andrews, 1916

(Fig. 2G)

Theropithecus (Theropithecus) oswaldi ssp. indet.

Geographic distribution: Africa, India, Spain and perhaps Israel.

Chronological range: Late Pliocene to Late Pleistocene.

Iberian localities: Cueva Victoria (Murcia).

Remarks: Here we follow the distinction in T. oswaldi of three distinct subspecies (Jablonski, 2002): late Early to Late Pleistocene remains of $T$. oswaldi are attributed to $T$. oswald $i$ leakeyi, whereas the remains from the late Early or Middle Pleistocene of India are attributed to T. oswaldi delsoni, morphologically more similar to the latter, and remains from the Late Pliocene to the Early Pleistocene of Africa are attributed to the nominotypical subspecies (Delson, 1993; Jablonski, 2002). The Iberian remains of Theropithecus, unambiguously recorded at Cueva Victoria by dental remains (Gibert et al., 1995), were attributed to T. o. oswaldi, although it is uncertain that it belongs to the same subspecies recorded in Africa (E. Delson, pers. com.). A phalanx from the same locality, originally attributed to humans (Gibert Clols and Pons Moyà, 1985; Gibert et al., 1985; Gibert and Pérez-Pérez, 1989), was later reassigned to Theropithecus (Martínez-Navarro et al., 2005); although no consensus has been reached in this regard (see discussion in Gibert et al., 2008; Martínez-Navarro et al., 2008), we tentatively favor the former interpretation.

Main references: Gibert et al. (1995); Martínez-Navarro et al. (2005).

$$
\begin{aligned}
& \text { Subfamily Colobinae Blyth, } 1863 \\
& \text { Tribe incertae sedis } \\
& \text { Genus Mesopithecus } \text { Wagner, } 1839 \\
& \text { Mesopithecus } \text { sp. }
\end{aligned}
$$

Geographic distribution: Eurasia.

Chronological range: Late Miocene to Pliocene.

Iberian localities: Venta del Moro (Valencia); Canal Negre I (Barcelona).

Remarks: The presence of the genus Mesopithecus in the Iberian Peninsula was first reported by Montoya et al. (2006) as Mesopithecus sp., on the basis of the Turolian remains from Venta del Moro (5.8-5.5 Ma). An ongoing study of the 
available dental remains from this locality will hopefully determine whether these remains correspond to the type species M. pentelicus (undoubtedly known from MN11-MN13 of Europe, Iran and Afghanistan) or to M. monspessulanus (from MN14-MN17 and perhaps also MN13 of Europe) (Andrews et al., 1996; Koufos, 2009). The presence of Mesopithecus in the Iberian Peninsula is further confirmed by the remains of uncertain age from Canal Negre reported by Guillén-Castejón (2010). The latter author attributed these remains to both M. pentelicus and Mesopithecus sp., but given age uncertainties and the lack of detailed metrical comparisons, here these remains are provisionally left unassigned to the species level.

Main references: Montoya et al. (2006); Guillén-Castejón (2010); Alba et al. (2010c).

\section{Genus Dolichopithecus Depéret, 1889}

Dolichopithecus ruscinensis Depéret, 1889

Geographic distribution: Europe and Russia.

Chronological range: Pliocene (4.0-3.2 Ma).

Iberian localities: Layna (Soria); Canal Negre I (Barcelona).

Remarks: A juvenile mandible from the Late Pliocene locality of Layna (4.2-3.6 Ma; Minwer-Barakat et al., 2012, their Fig. 6), even though not described in detail, was attributed to this colobine species by Delson (1973, 1974; also Szalay and Delson, 1979; Pérez and Soria, 1990; Moyà Solà et al., 1990). A single molar from Canal Negre, of uncertain age, was also assigned to this taxon (albeit with some doubts) by Guillén-Castejón (2010).

Main references: Delson (1973, 1974); Moyà Solà et al. (1990); Guillén-Castejón (2010).

\section{Superfamily Hominoidea Gray, 1825 \\ Family Hominidae Gray, 1825 \\ Subfamily incertae sedis Hominidae indet.}

Iberian localities: Abocador de Can Mata locality ACM/ C1-E* (Barcelona).

Remarks: With an estimated age of 12.3-12.2 Ma (MN7, late Aragonian), the two partial upper postcanine series of a single individual from $\mathrm{ACM} / \mathrm{C} 1-\mathrm{E}^{*}$ constitute the oldest hominoid record from the Vallès-Penedès Basin (CasanovasVilar et al., 2011; Alba et al., 2012a). The description and study of these remains, currently under way, will hopefully enable to ascertain whether they correspond to any of the other dryopithecin taxa recorded at Abocador de Can Mata (Pierolapithecus, Anoiapithecus, Dryopithecus) or to another, otherwise unrecorded hominid taxon.

Main references: Casanovas-Vilar et al. (2011); Alba et al. (2012a).

Subfamily Dryopithecinae Gregory and Hellman, 1939

Tribe incertae sedis

Dryopithecinae indet.
Iberian localities: Hostalets de Pierola indeterminate, Can Mata 1, Sant Quirze, and Abocador de Can Mata localites $\mathrm{ACM} / \mathrm{C} 4-\mathrm{Cp}$ and ACM/BCV4 (Barcelona).

Remarks: Several upper teeth of a single individual from $\mathrm{ACM} / \mathrm{C} 4-\mathrm{Cp}$ and a mandibular fragment from $\mathrm{ACM} / \mathrm{BCV} 4$, with similar estimated ages of $11.9 \mathrm{Ma}$ (late Aragonian), are currently under study; attributed to Hominidae indet. by Casanovas-Vilar et al. (2011), their dental morphology indicates that they can be attributed to the Dryopithecinae, and most likely, any of the three dryopithecine genera recorded at Abocador de Can Mata (Pierolapithecus, Anoiapithecus, Dryopithecus). An isolated upper molar from Hostalets de Pierola indeterminate, initially mistaken for a suid, was attributed by van der Made and Ribot (1999) to Dryopithecus. Given the greater diversity of hominoids evidence in the area of Hostalets during the last decade, Casanovas-Vilar et al. (2011) merely attributed it to the Hominidae, although on the basis of its occlusal morphology, an attribution to the Dryopithecinae is warranted. A female lower canine from the same area, in particular from the locality of Can Mata 1 (ca. 11.2 Ma, MN8, late Aragonian), was tentatively attributed to Hispanopithecus laietanus by Crusafont-Pairó and Golpe-Posse (1973a), and subsequently Golpe Posse (1993) reafirmed such attribution. Again, given the unexpected diversity of dryopithecines in this area, and the lack of homologous material for the three above-mentioned genera, Casanovas-Vilar et al. (2011) attributed this canine to Hominidae indet., although an assignment to the Dryopithecinae is most likely. Finally, a fragment of molar crown attests the presence of dryopithecines in the locality of Sant Quirze (11.8-11.2 Ma, MN8, late Aragonian); attributed to H. laietanus in the past (Golpe Posse, 1993), and most recently to Hominidae indet. (Casanovas-Vilar et al., 2011), the preserved morphology precludes an attribution to the genus level.

Main references: Crusafont-Pairó and Hürzeler (1969); Crusafont-Pairó and Golpe-Posse (1973a, 1974); Moyà Solà et al. (1990); Golpe Posse (1993); van der Made and Ribot (1999); Casanovas-Vilar et al. (2011); Alba et al. (2012a).

"Sivapithecus" occidentalis Villalta Comella and Crusafont Pairó, 1944 (nomen dubium) (Fig. 2K)

Geographic distribution: Exclusively known from the type locality.

Chronological range: $12.5-11.5 \mathrm{Ma}$.

Iberian localities: Can Vila [type locality] (Barcelona).

Remarks: This nominal taxon is based on two lower molars of a single individual (Villalta Comella and Crusafont Pairó, 1941, 1944; Pickford, 2012) from the locality of Can Vila, of uncertain stratigraphic provenance (Moyà-Solà et al., 2004; Casanovas-Vilar et al., 2011). Initially attributed to Dryopithecus fontani by Villalta Comella and Crusafont Pairó (1941), the same authors subsequently used them to erect a new taxon (Villalta Comella and Crusafont Pairó, 1944), which was subsequently synonymized with Hispanopithecus 
laietanus. According to the description of the site location provided by Villalta Comella and Crusafont Pairó (1941), the type locality must have been situated within or very near the area of Abocador de Can Mata, with an estimated age of 12.5-11.5 Ma (Casanovas-Vilar et al., 2011). However, according to the recollections of Jordi Martinell (pers. comm. to DMA), the classical locality of Can Vila would have been situated in the Barranc de Can Vila, in a lower stratigraphic position than BCV1 (the type locality of Pierolapithecus catalaunicus), in which case an estimated age of 12.1-11.9 Ma would be attributable to the former. Even though an attribution to the genus Sivapithecus can be readily dismissed, "Sivapithecus" occidentalis remains a nomenclaturally valid taxon, whose taxonomic affinities remain to be ascertained. This is complicated by the presence of several dryopithecine genera at Abocador de Can Mata around 11.9-11.8 Ma, and especially by the lack of lower teeth attributable to Pierolapithecus catalaunicus. At the species level, "S." occidentalis is potentially a senior synonym of $P$. catalaunicus, in which case, the former would take precedence. However, this potential synonymy cannot be resolved on the basis of currently available material, so we concur with other authors (MoyàSolà et al., 2004; Casanovas-Vilar et al., 2011) that this nominal taxon is best considered a nomen dubium. Most recently, Pickford (2012) synonymized "S." occidentalis with Neopithecus brancoi (Schlosser, 1901); the latter, however, has been also considered a nomen dubium by Casanovas-Vilar et al. (2011). Additional material is required to solve this taxonomic and nomenclatural conundrum.

Main references: Villalta Comella and Crusafont Pairó (1941, 1944); Golpe Posse (1993); Moyà-Solà et al. (2004); Pickford (2012); Alba (2012).

Tribe Dryopithecini Gregory and Hellman, 1939

Genus Dryopithecus Lartet, 1856

Dryopithecus fontani Lartet, 1856

(Fig. 2H)

Geographic distribution: Spain, France and Austria.

Chronological range: MN7 and MN8, late Aragonian (Middle Miocene).

Iberian localities: Abocador de Can Mata localities ACM/ C3-Ae and ACM/C4-Ap.

Remarks: A partial face of an adult male individual from ACM/C3-Ae (11.9 Ma, MN7 or MN8, late Aragonian) was attributed to Dryopithecus fontani by Moyà-Solà et al. (2009a) on the basis of several craniodental features that do not fit with other Vallès-Penedès hominoids. If this attribution is correct, this is the only specimen representing the facial morphology of the type species of Dryopithecus, otherwise known from several mandibles and a few isolated upper teeth. On the basis of the Abocador de Can Mata specimen, $D$. fontani displays a mosaic of derived great-ape features, coupled with several primitive hominoid retentions and several gorilla-like features of uncertain phylogenetic interpretation
(Moyà-Solà et al., 2009a). An upper male canine from ACM/ C4-Ap (11.9 Ma, MN7 or MN8, late Aragonian), figured but incorrectly attributed by Pickford (2012) to Hispanopithecus laietanus, is in fact attributable to Dryopithecus fontani (Alba and Moyà-Solà, 2012b).

Main references: Moyà-Solà et al. (2009a); Begun (2009); Alba et al. (2010b, c); Casanovas-Vilar et al. (2011); Pickford (2012); Begun et al. (2012); Alba and Moyà-Solà (2012b).

\section{cf. Dryopithecus fontani Lartet, 1856}

Iberian localities: Abocador de Can Mata locality ACM/ C3-Az and Castell de Barberà (Barcelona).

Remarks: A partial (proximal) femur from $\mathrm{ACM} / \mathrm{C} 3-\mathrm{Az}$, with an estimated age of $11.9 \mathrm{Ma}$ (MN7 or MN8, late Aragonian), and an estimated body mass around $44 \mathrm{~kg}$, has been tentatively attributed to $D$. fontani mainly on the basis of its large size (Moyà-Solà et al., 2009a). This specimen displays several modern hominoid-like characteristics, coupled with pronograde-related features, suggesting a greater emphasis on quadrupedalism than in Hispanopithecus laietanus (Moyà-Solà et al., 2009a). With regard to Castell de Barberà (ca. 11.2-10.5 Ma), the presence of hominoids at this locality was originally reported on the basis of a purported female upper canine (e.g., Golpe Posse, 1993), which in fact belongs to a male specimen of Barberapithecus (Begun, 2002a; Alba and Moyà-Solà, 2012a). However, the undoubted presence of hominoids at Castell de Barberà is documented by two (proximal and distal) pollical phalanges as well as a partial humeral diaphysis (Moyà Solà et al., 1990; Alba et al., 2011a; Almécija et al., 2011, 2012). The humeral diaphysis displays several modern hominoid-like features, most closely resembling the more complete and slender (presumably female) humerus of $D$. fontani from Saint Gaudens in France (Alba et al., 2011a). The phalanges more closely resemble those of other Miocene apes than those of extant great apes, indicating a significant degree of thumb-assisted, powerful grasping during above-branch quadrupedalism and cautious climbing (Almécija et al., 2012).

Main references: Moyà-Solà et al. (1990, 2009a); Casanovas-Vilar et al. (2011); Alba et al. (2011a, 2012a); Almécija et al. (2011, 2012).

Genus Pierolapithecus Moyà-Solà et al., 2004

Pierolapithecus catalaunicus Moyà-Solà et al., 2004

(Fig. 2I)

Geographic distribution: Exclusively known from the type locality.

Chronological range: 11.9 Ma (MN7, late Aragonian, Middle Miocene).

Iberian localities: Abocador de Can Mata - Barranc de Can Vila 1 (ACM/BCV1) [type locality] (Barcelona).

Remarks: The holotype and currently only known individual of this taxon includes a partial face and skeleton with 
more than 80 bones or bone fragments from an adult male individual (Moyà-Solà et al., 2004), with an estimated body mass of $34 \mathrm{~kg}$. Although an age of ca. 12.5-13.0 Ma was initially proposed (Moyà-Solà et al., 2004), based on magnetostratigraphic data, ACM/BCV1 has been subsequently dated to 11.9 Ma (Moyà-Solà et al., 2009a; Casanovas-Vilar et al., 2011; Alba et al., 2012a). Pierolapithecus displays a low face with a posteriorly-situated glabella and a prognathous profile, coupled with a modern, great-ape-like facial configuration (Moyà-Solà et al., 2004). In turn, the postcranial remains indicate that Pierolapithecus possessed a modern-hominoid-like, orthograde bodyplan (Moyà-Solà et al., 2004; Ward, 2007; Susanna et al., 2010), so that this taxon represents the oldest evidence of orthogrady combined with a cranial morphology more derived than that of hylobatids. On this basis, Pierolapithecus was originally interpreted as a stem hominid, i.e. as a basal member of the great-ape-andhuman clade (Moyà-Solà et al., 2004, 2009b), although the possession of several pongine-like cranial features (such as the lack of frontal sinus; Pérez de los Ríos et al., 2010, 2012) suggest that it might be alternatively interpreted, probably together with other dryopithecins, as a sister-taxon of the Asian Pongini (see discussion in Casanovas-Vilar et al., 2011; Alba, 2012; Pérez de los Ríos et al., 2012). Interestingly, despite its orthograde body plan, Pierolapithecus still retains manual adaptations for powerful-grasping and above-branch palmigrady (Moyà-Solà et al., 2004, 2005; Almécija et al., 2009) further suggesting that unlike Hispanopithecus (see below) this taxon lacked adaptations to below-branch suspensory behaviors (Moyà-Solà et al., 2005; Almécija et al., 2009; Alba et al., 2010a; for an alternative interpretation, see Begun and Ward, 2005; Deane and Begun, 2008, 2010). Some authors (Begun, 2009; Begun et al., 2012) remain skeptical on the taxonomic distinctiveness of Pierolapithecus from Dryopithecus, but this is contradicted by several differences in craniodental morphology (Moyà-Solà et al., 2004, 2009a), including the possession of much thicker-enameled molars in Pierolapithecus (Alba et al., 2010b; contra Begun, 2009).

Main references: Moyà-Solà et al. (2004, 2005, 2009b); Begun and Ward (2005); Deane and Begun (2008, 2010); Almécija et al. (2009); Begun (2009); Alba et al. (2010a, b, c, 2011d); Pérez de los Ríos et al. (2010); Susanna et al. (2010); Begun et al. (2012); Alba (2012); Pérez de los Ríos et al. (2012).

\section{Genus Anoiapithecus Moyà-Solà et al., 2009b Anoiapithecus brevirostris Moyà-Solà et al., 2009b}

(Fig. 2J)

Geographic distribution: Exclusively known from the type locality.

Chronological range: 11.9 Ma (MN7, late Aragonian, Middle Miocene).

Iberian localities: Abocador de Can Mata locality ACM/ C3-Aj [type locality] (Barcelona).
Remarks: A. brevirostris has been described on the basis of a partial face and associated mandible from $\mathrm{ACM} / \mathrm{C} 3-\mathrm{Aj}$ (Moyà-Solà et al., 2009b), although unpublished dental remains from a second individual have been recovered from the same locality. As for Pierolapithecus, doubts have been raised regarding the distinct taxonomic status of Anoiapithecus relative to Dryopithecus (Begun, 2009; Begun et al., 2012). In fact, however, Anoiapithecus can be distinguished from both Pierolapithecus and Dryopithecus by the strikingly orthognathous facial profile of the former (Moyà-Solà et al., 2009 b), which cannot be merely discounted on the basis of purported distortion (contra Begun et al., 2012). Moreover, Anoiapithecus further differs from the other dryopithecins by several other craniodental features, most notably, in the case of Pierolapithecus, by the presence of a frontal sinus (MoyàSolà et al., 2009b; Pérez de los Ríos et al., 2010, 2012). Nevertheless, the three dryopithecin genera display several hominid facial synapomorphies, suggesting that they are more closely related to crown hominids than to kenyapithecines from the earlier Middle Miocene (Moyà-Solà et al., 2009b; Casanovas-Vilar et al., 2011).

Main references: Moyà-Solà et al. (2009b); Begun (2009); Alba et al. (2010b, c, 2011d); Pérez de los Ríos et al. (2010); Begun et al. (2012); Alba (2012).

Tribe Hispanopithecini Cameron, 1997

Genus Hispanopithecus Villalta Comella and Crusafont Pairó, 1944

Subgenus Hispanopithecus Villalta Comella and Crusafont Pairó, 1944

Hispanopithecus (Hispanopithecus) laietanus Villalta Comella and Crusafont Pairó, 1944

(Fig. 2N-O).

Geographic distribution: Only known from several localities of the Vallès-Penedès Basin (NE Spain).

Chronological range: $10.0-9.5 \mathrm{Ma}$ (MN9-MN10, early to late Vallesian, Late Miocene).

Iberian localities: La Tarumba 1 [type locality], Can Llobateres 1 and 2, Polinyà 2, Can Feu, EDAR6 and EDAR7 (Barcelona).

Remarks: H. laietanus (the type species of the genus Hispanopithecus) was originally defined on the basis of lower jaw and dental remains from La Tarumba 1 (Villalta Comella and Crusafont Pairó, 1944). Subsequently, Hispanopithecus was treated as a junior subjective synonym of Dryopithecus by many authors (Szalay and Delson, 1979; Moyà Solà et al., 1990; Begun et al., 1990; Harrison, 1991; Andrews et al., 1996; Begun, 1992, 2002b), albeit with some exceptions (Golpe Posse, 1993; Cameron, 1997, 1999). Recently, Hispanopithecus was resurrected (Moyà-Solà et al., 2009a), including not only the type species, but also $H$. crusafonti (see below) - a proposal that has been subsequently followed by most researchers (e.g., Begun, 2009; Alba et al., 2010a, 2011a, b, 2012b; Begun et al., 2012). Dental remains 
of $H$. laietanus are known from several localities, although the largest sample comes from the early Vallesian site of Can Llobateres 1 (Begun et al., 1990; Harrison, 1991; Golpe Posse 1993; Alba et al. 2012b), with an estimated age of $9.7 \mathrm{Ma}$. The intial hominoid dental finds from Can Llobateres 1 were attributed to $H$. laietanus, but subsequent finds resulted in the naming of two additional taxa (Dryopithecus piveteaui and Rahonapithecus sabadellensis), which are currently considered nomina nuda (e.g., Golpe Posse, 1993; but see Pickford, 2012). During the last decades, the dental sample from this locality has been generally attributed to a single species (e.g., Begun et al., 1990; Harrison, 1991; Alba et al., 2012c), with some authors setting apart an upper canine (Crusafont-Pairó and Golpe-Posse, 1973a; Golpe Posse, 1993) that nevertheless can be also attributed to the same taxon. With regard to the cranial anatomy of $H$. laietanus, it is known by a partial cranium from Can Llobateres 2 (Moyà-Solà and Köhler, 1993a, 1995; Köhler et al., 2001a, b), with an estimated age of 9.6 Ma. This taxon displays several cranial features indicative of hominid status, being in some regards more derived towards the modern great-ape condition than the Middle Miocene dryopithecins. Finally, besides some isolated bones from Can Llobateres 1 and the unpublished remains from EDAR (Checa Soler and Rius Font, 2003), the postcranial anatomy of $H$. laietanus is best known from the partial skeleton (comprising about 60 elements) from Can Llobateres 2 (Moyà-Solà and Köhler, 1996; Köhler et al., 2001a; Almécija et al., 2007) and the more incomplete partial skeleton from Can Feu (Alba et al., 2011b, 2012d). Several features of these skeletons indicate the possession of an orthograde body plan with suspensory adaptations (Moyà-Solà and Köhler, 1996; Köhler et al., 2002; Almécija et al., 2007; Alba et al., 2010a; Susanna et al., 2011; Pina et al., 2012a,b), although some manual features and other anatomical characteristics indicate the simultaneous retention of features functionally-related to above-branch quadrupedalism (Almécija et al., 2007; Alba et al., 2010a, 2012d).

Main references: Villalta Comella and Crusafont Pairó (1944); Crusafont Pairó (1958b, 1965a); Crusafont-Pairó and Hürzeler (1961, 1969); Crusafont-Pairó and GolpePosse (1973a); Golpe Posse (1982a, 1993); Moyà Solà et al. (1990); Begun et al. (1990); Harrison (1991); Moyà-Solà and Köhler (1993a, 1995, 1996); Andrews et al. (1996); Cameron (1997, 1999); Köhler et al. (1999, 2001a, b, 2002); Ribot et al. (1996); Begun (2002b, 2009); Checa Soler and Rius Font (2003); Almécija et al. (2007); Deane and Begun (2008); Alba et al. (2010a, c, 2011b, 2012b,c,d); Casanovas-Vilar et al. (2011); Susanna et al. (2011); Pickford (2012); Pina et al. (2012b); Alba (2012).

Hispanopithecus (Hispanopithecus) crusafonti (Begun, 1992) (Fig. 2L-M).

Geographic distribution: NE Spain.

Chronologic range: 10.4-10.0 (MN9, early Vallesian, Late Miocene).
Iberian localities: Can Poncic 1 [type locality] (Barcelona); Teuleria del Firal (Lleida).

Remarks: Most of the dentognathic remains attributed to $H$. crusafonti come from Can Poncic 1. Although initial finds were assigned to Hispanopithecus laietanus, after the recovery of more abundant material, Dryopithecus crusafonti was distinguished (Begun, 1992); it was recently transferred to the genus Hispanopithecus by Moyà-Solà et al. (2009a). After its description, this taxon has been accepted (Begun, 2002b; Casanovas-Vilar et al., 2011; Pickford, 2012), questioned (Andrews et al., 1996), or formally synonymized with H. laietanus (Ribot et al., 1996). On the basis of dental differences between the Can Poncic 1 sample and those of $H$. laietanus from later Vallesian localities (Begun, 1992), a distinct species status is favored here, following Alba et al. (2012c). At the same time, several shared-derived dental features suggest that they belong to a single genus, even though the lack of cranial material from Can Poncic makes the generic attribution to Hispanopithecus somewhat provisional, and some authors maintain its original assignment to Dryopithecus (Pickford, 2012). The partial mandible from Teuleria del Firal (Vidal, 1913a, b; Woodward, 1914), traditionally attributed to Dryopithecus fontani (Harrison, 1991; Andrews et al., 1996; Ribot et al., 1996), is also included here in the hypodigm of H. crusafonti (Begun, 1992; Casanovas-Vilar et al., 2011; Alba et al., 2012c), given some dental differences relative to $D$. fontani from France and several resemblances to the few lower teeth available from Can Poncic 1.

Main references: Vidal (1913a, b); Woodward (1914); Golpe Posse (1982a, 1993); Moyà Solà et al. (1990); Harrison (1991); Begun (1992, 2002b, 2009); Andrews et al. (1996); Ribot et al. (1996); Alba et al. (2010c); Casanovas-Vilar et al. (2011); Pickford (2012); Alba et al. (2012c); Alba (2012).

\section{Subfamily Homininae Gray, 1825 \\ Tribe Hominini Gray, 1825 \\ Genus Homo Linnaeus, 1758 \\ Homo sp.}

Iberian localities: Sima del Elefante TE9 (Burgos).

Remarks: The partial mandible recovered from the Early Pleistocene site (ca. 1.2 Ma) of Sima del Elefante (Atapuerca) was initially assigned to $H$. antecessor by Carbonell et al. (2008), but most recently it has been argued that it might correspond to a different taxon (Bermúdez de Castro et al., 2011). On this basis, we prefer to leave unassigned to the species level the remains from this locality, which represent the oldest osteological record of the genus Homo in the Iberian Pensinsula. Slightly older stone tool assemblages from Fuente Nueva-3 and Barranco León-5 in Orce (Guadix-Baza Basin) further record the early presence of humans in southern Iberia (Martínez-Navarro et al., 1997; Oms et al., 2000), although the even older (1.4 Ma; Duval et al., 2011), purported human remains from Venta Micena (e.g., Gibert et al., 2002), in the same region, are not currently accepted as 
such (Moyà-Solà \& Köhler, 1997; Martínez-Navarro, 2002; Martínez-Navarro et al., 1997).

Main references: Carbonell et al. (2008), Bermúdez de Castro et al. (2011); Martinón-Torres et al. (2011).

\section{Homo heidelbergensis Schoetensack, 1908 s.l.}

Geographic distribution: Eurasia and Africa.

Chronological range: Latest Early Pleistocene to Middle Pleistocene.

Iberian localities: Gran Dolina TD6 and Sima de los Huesos in Atapuerca (Burgos); Cueva Negra del Estrecho del Quípar (Murcia); Galeria Pesada - Gruta da Aroeira (Ribatejo); Cova de Mollet I (Girona).

Remarks: The classification of latest Early and Middle Pleistocene humans is still one of the most hotly debated topics in paleoanthropology and remains largely unresolved (e.g., Rightmire, 2007; 2008; Hublin, 2009; Harvati et al., 2010). Traditionally, they were lumped, together with Neandertals, into a single informal category termed 'archaic' $H$. sapiens. In this way, the phylogenetic affinities of such taxa with later Homo and their mosaic morphology, showing a combination of plesiomorphic (Homo erectus-like) traits with some more derived features, were recognized. However, such grade classification failed to address the alpha taxonomy of these specimens (Harvati et al., 2010). Currently, there are two main views on the phylogeny and taxonomy of these forms (Rightmire, 2007; Hublin, 2009). One considers that there is a single species $H$. heidelbergensis s.l., which would be ancestral to both Homo neanderthalensis and modern H. sapiens, being distributed in Europe, Africa and probably Asia (e.g., Rightmire, 1998, 2007, 2008; Mounier et al., 2009). Alternatively, several authors (e.g., Arsuaga et al., 1997) have argued that European Middle Pleistocene humans display several Neandertal derived features, thereby indicating that these forms should be classified into H. neanderthalensis, or alternatively that $H$. heidelbergensis should be restricted to European forms (a chronospecies ancestral to Neandertals, i.e. H. heidelbergensis s.s.), their African counterparts being attributed to a different species, H. rhodesiensis (see also Stringer, 2012).

The hominin remains from Sima de los Huesos (0.53 Ma; but see Stringer, 2012, regarding dating uncertainties) were initially attributed to Homo heidelbergensis by Arsuaga et al. (1993), although most recently Martinón-Torres et al. (2012) argued that the dental remains from this locality display more derived Neandertal traits than the typical $H$. heidelbergensis from Mauer or Aragó. We however think that an attribution to $H$. heidelbergensis is still warranted, especially when it is taken into account that this taxon is here considered in a broad sense. Similarly, the older hominin remains from Gran Dolina TD6 (ca. 0.88-0.78 Ma) were also initially assigned to an archaic form of $H$. heidelbergensis by Carbonell et al. (1995), but later Bermúdez de Castro et al. (1997) erected a new species, Homo antecessor, arguing that it would be the common ancestor of both modern humans and Neandertals. Such a phylogenetic hypothesis is currently uncertain, although the validity of the species, definitely identified only from Atapuerca, is accepted by some researchers (Stringer, 2012). Its distinctive taxonomic status, either at the species or subspecies level, might ultimately be vindicated in the future by the find of additional remains. Currently, however, the available remains from TD6 are relatively scarce, fragmentary and/or subadult, and one of its purported most diagnostic features (the development of the canine fossa) is much more obvious in the juvenile than in the adult specimen, this feature further being variable in other populations attributed to $H$. heidelbergensis (Rightmire, 2008). Resolving the taxonomy of fossil European hominins is of course outside the scope of this paper. However, given recent taxonomic analyses favoring the distinction of a single, Afro-European species $H$. heidelbergensis s.1. (Mounier et al., 2009; see Stringer, 2012, for a recent review on this species), we provisionally prefer to attribute the Gran Dolina hominins to the latter taxon. The somewhat younger population from Sima de los Huesos, on the other hand, display a mosaic of morphologic features indicating that they are already derived towards Neandertals (Martinón-Torres et al., 2012), so that their removal from $H$. heidelbergensis and their inclusion into $H$. neanderthalensis might be justified (Stringer, 2012). Following the same criterion of $H$. heidelbergensis understood in a broad sense, the Middle Pleistocene remains from Cueva Negra del Estrecho de Quípar (Walker et al., 2010), Galeria Pesada (Trinkaus et al., 2003) and Cova de Mollet (Maroto et al., 1987) are here also attributed to $H$. heidelbergensis s.l.

Main references: Arsuaga et al. (1993, 1997, 1999); Carbonell et al. (1995, 2005); Bermúdez de Castro et al. (1997, 2008, 2012a); Carretero et al. (1999); Lorenzo et al. (1999); Trinkaus et al. (2003); Maroto et al. (1987); Walker et al. (2010); Martinón-Torres et al. (2012); Maroto et al. (2012).

\section{Homo neanderthalensis King, 1864}

Geographic distribution: Europe and Middle East. Chronological range: Latest Middle to Late Pleistocene.

Iberian localities: Banyoles (Girona); Cova del Gegant (Barcelona); Cova del Tossal de la Font (Castellón); Cova Negra, Cova del Bolomor and Cova Foradà (Valencia); El Salt (Alicante); Sima de las Palomas del Cabezo Gordo (Murcia); Cueva de los Moros de Gabasa (Huesca); Pinilla del Valle (Madrid); Valdegoba (Burgos); Cueva del Castillo, Cueva del Esquilleu, Cueva de Covalejos and Cueva del Castillo (Cantabria); Cueva del Sidrón (Oviedo); Arrillor (Álava); Axlor (Vizcaya); Lezetxiki VII, IV (Guipúzcoa); Cueva de los Casares and Cueva de los Torrejones (Guadalajara); Cueva del Boquete de Zafarraya (Málaga); Cueva de La Carihuela (Granada); Forbe's Quarry (=Gibraltar I), Devil's Tower (=Gibraltar II) and Cueva Genista (Gibraltar, UK); Gruta da Figueira Brava (Setúbal); Gruta de Salemas (Lisboa); Gruta 
da Oliveira (Santarém); Gruta Nova da Columbeira (Leiria); Lapa da Rainha (Lisboa).

Remarks: There are more than 30 Iberian localities where osteological remains of $H$. neanderthalensis have been found, although no partial or complete skeletons have been unearthed up to date. Several of these localities, situated in southwestern Iberia, record the latest Neandertals from Europe (Hublin et al., 1995), with a chronology of $35 \mathrm{ka}$ (Trinkaus, 2007).

Main references: Alférez et al. (1982, 1985); Dean et al. (1986); Arsuaga et al. (1984, 1989, 2007); Antunes and Santinho Cunha (1992); Hublin et al. (1995); Sanchez (1999); Quam et al. (2001); Barroso (2003); Daura et al. (2005); Grün et al. (2006); Rosas et al. (2006); Aguirre Enríquez (2007); Trinkaus et al. (2007); Walker et al. (2008, 2010, 2011); Arsuaga et al. (2012).

\section{Homo sapiens Linnaeus, 1758}

Chronological range: Latest Middle Pleistocene to Holocene. Geographic distribution: Worldwide.

Oldest Iberian localities: Gruta do Caldeirão (Santarém); Lagar Velho (Leiria); Malladetes (Valencia).

Remarks: There are numerous Iberian localities with fossil remains of $H$. sapiens, so that only the oldest citations are provided above. On the basis of osteological remains, H. sapiens is first recorded at the Iberian Peninsula in Lagar Velho (Duarte et al., 1999) and Malladetes (Arsuaga et al., 2002), and slightly later at Gruta do Caldeirão (Trinkaus et al., 2001). These remains of modern humans postdate the last Iberian Neandertals, but this is not the case of the archeological remains associated to the former. Thus, although the attribution of archeological remains to a particular human species is questionable when not accompanied by osteological remains, the recent dating of Paleolithic cave art from Spainpresumably made by $H$. sapiens - to $40.8 \mathrm{ka}$ suggests that modern humans arrived to the Iberian Peninsula ca. $41.5 \mathrm{ka}$, like in other areas of Western Europe (Pike et al., 2012). The find of an almost complete skeleton of a child in the Lagar Velho cave caused a lot of controversy, because Duarte et al. (1999) initially concluded that it displayed modern human and Neandertal traits simultaneously. Subsequently, however, other authors have pointed out that the Lagar Velho child is clearly $H$. sapiens and does not display Neandertal characters (Tattersall and Schwartz, 1999).

Main references: Duarte et al. (1999); Arsuaga et al. (2002); Trinkaus et al. (2001).

\section{Results}

An updated summary of Iberian primate taxa and localities from the Cenozoic is provided here, based on the revision of more than 200 bibliographic references. A total of 25 primate genera, corresponding to 7 families (one of plesiadapiforms, 2 of strepsirrhines and 4 of haplorrhines), from up to 116 different localities, are reported ( 27 from the Eocene, 3 from the Oligocene, 32 from the Miocene, 4 from the Pliocene, 51 from the Pleistocene and one with an undetermined age). This information is summarized in Figures 3 and 4, which show the ranges of the different Iberian primate taxa in relation to climatic evolution during the Cenozoic. In the following section, we discuss primate diversity dynamics in the Iberian Peninsula through time, further emphasizing its interplay with global and regional paleogeographic and climatic events.

\section{Discussion}

\subsection{Iberian primate diversity in the Paleogene (Fig. 3)}

In Europe, the earliest occurrence of plesiadapiforms is dated to the Late Paleocene, as documented by the record of Berruvius and some members of the Saxonellidae and Plesiadapidae in France and Germany (Silcox, 2001; Bloch et al., 2007). In contrast, the record of primates (including plesiadapiforms) in the Iberian Peninsula does not go back beyond the Early Eocene. This lack of evidence for Paleocene primates in Iberia may be due to the scarcity of Paleocene continental sites: mammal remains from this epoch have been only identified in the localities of Claret, Tendruy, Palau, Fontllonga and Campo (Gheerbrant et al., 1997; López-Martínez and Peláez-Campomanes, 1999; Peláez-Campomanes et al., 2000). Anyway, the Eocene record of plesiadapiforms in this area is sparse, being restricted to the paromomyoid Arcius, known from the locality of Silveirinha (Mondego Basin, Portugal; Estravís, 2000) and recently identified also in Masia de l'Hereuet (Àger sub-basin, Spain; Marigó et al., 2012a). In the former locality, eight isolated teeth enabled description of the species A. zbyszewskii, whereas the four molars recovered from the latter site did not allow a specific determination.

The record of euprimates during the Iberian Eocene shows a much greater diversity, being represented by two distinct groups of Paleogene "prosimians": adapoids and omomyoids ( 8 and 3 genera, respectively, apart from several forms without generic ascription, which in some cases may lead to the description of new taxa after further studies). The record of adapoids begins, together with that of plesiadapiforms, in the Neustrian, with the presence of the genus Donrussellia in the Mondego Basin. In the Grauvian, the genera Cantius and Agerinia are well represented in several localities from the Pyrenean and Ebro basins, Agerinia persisting into the Geiseltalian. The Robiacian records a great diversity of adapoids, represented in the Pyrenean and Duero basins by the genera Anchomomys, Mazateronodon, Microadapis, Adapis and Leptadapis, the latter two being also identified in Headonian levels. With respect to omomyoids, the genus Pseudoloris has its oldest record in the Iberian locality of Casa Ramón (Geiseltalian). It is also well represented, together with Necrolemur, in the Robiacian and Headonian, while Microchoerus is recognized in several Headonian sites. Such 


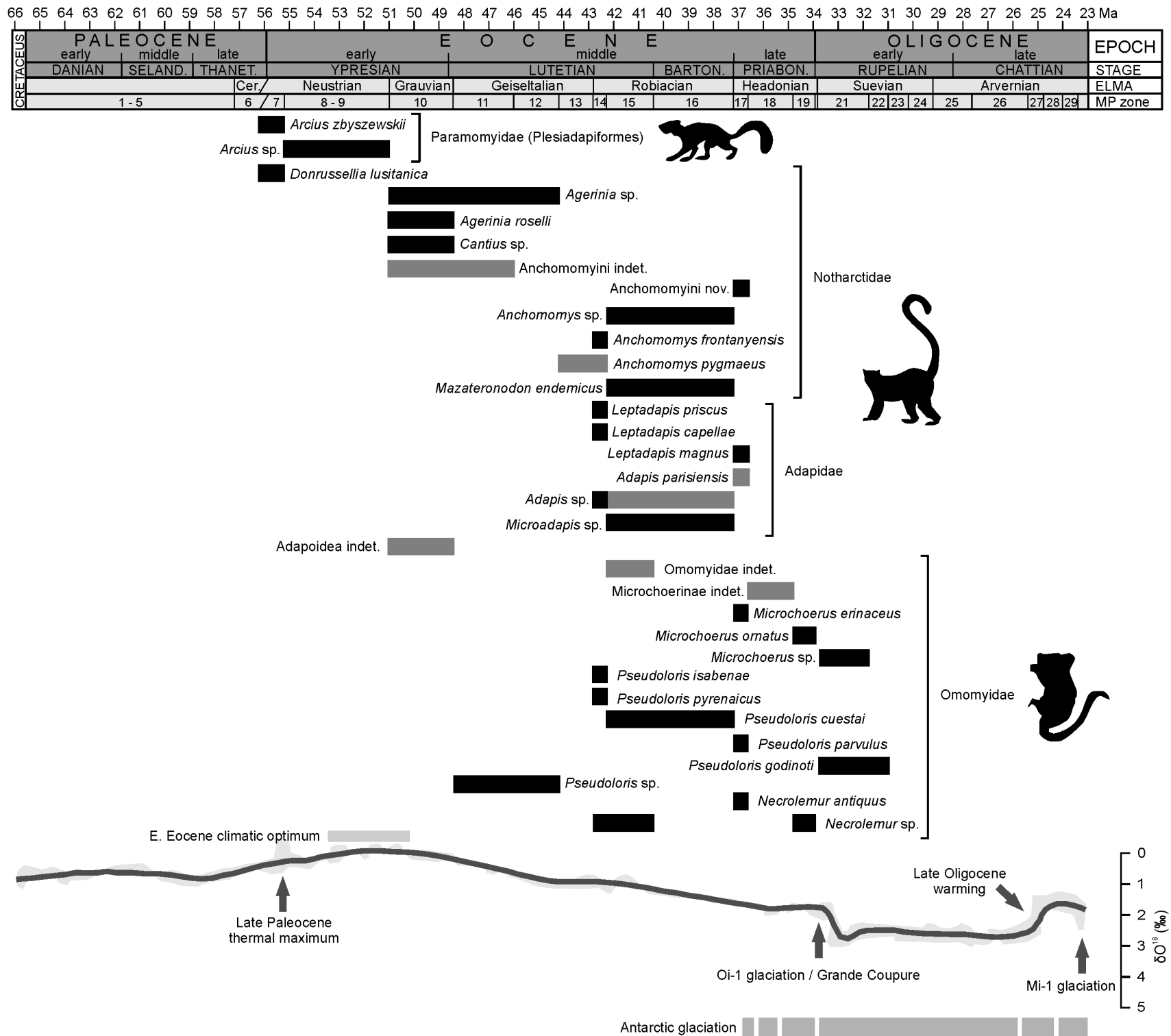

Fig. 3.- Range chart of Paleogene Iberian primate taxa. Uncertain attributions (cf., indet.) are shown in dark gray, whereas nomina nuda and nomina dubia are not considered. The global oxygen isotope record, together with the development of ice-sheets and major climatic/physiographic events, are also included. Age boundaries for epochs, stages, European Land Mammal Ages (ELMA) and Paleogene Mammal Zones (MP) are after Luterbacher et al. (2004). Climatic data are taken from Zachos et al. (2001).

abundance and diversity of both adapoids and omomyoids parallels the diversity peak that primates experienced during the Eocene in the Northern hemisphere (e.g., Fleagle, 1999). The Eocene represents the warmest epoch of the Tertiary, especially during the Paleocene/Eocene Thermal Maximum and the subsequent sustained period of global warmth known as the Early Eocene Climatic Optimum (Zachos et al., 2001). Warm temperatures and not-marked seasonality favored the development of tropical forests with a predominance of evergreen thermophilic elements in latitudes as far north as $50^{\circ}$ (Collison and Hooker, 2003). Although variable in different regions and time intervals, these dense forests would have provided suitable habitats for the radiation of these groups of prosimians.
During the Middle and Late Eocene, the mammal faunas from the western and central Iberian basins were clearly different from those of the Pyrenean basins, the latter being similar to those from Central Europe (France and Switzerland). This faunal differentiation, mainly observed in perissodactyls, artiodactyls and rodents, led to the definition of the Western Iberian Bioprovince (Cuesta, 1991), which included several western and central Iberian basins (Duero, Almazán and Oviedo Basins) characterized by Eocene mammal faunas different from those of the Pyrenees and the rest of Europe. Subsequent studies of these mammalian groups have further reinforced this contention (see Badiola et al., 2009, and references therein). The recent description of the adapiform $\mathrm{Ma}$ zateronodon endemicus and the microchoerine Pseudoloris cuestai (Marigó et al., 2010; Minwer-Barakat et al., 2012) 
from the site of Mazaterón demonstrates that primates from the Western Iberian Bioprovince were also clearly different from their counterparts in the Pyrenean basins, thus reinforcing the endemic nature of the mammal faunas from this bioprovince.

The Eocene-Oligocene boundary was marked by a major faunal turnover that dramatically affected the continental vertebrate faunas and involved the extinction of a large number of Eocene mammals. This global event, named the "Grande Coupure" by Stehlin (1910), was mainly related to the climatic deterioration that took place at the Eocene-Oligocene transition, which led to a marked loss of diversity in both the marine and continental realms (Prothero, 1994; Hooker et al., 2004). Primates were not an exception, and the number of species of both adapoids and omomyoids, which had been highly succesful during the Eocene, drastically decreased in the Early Oligocene. Adapiforms persisted until the Miocene, although their record is very scarce and geographically restricted to Southeastern Asia (Gebo, 2002), whereas in Europe there is no mention of this group after the EoceneOligocene boundary. Regarding omomyoids, there are some brief appearances in the Oligocene and the earliest Miocene of North America (MacDonald, 1963; Albright, 2005) and Egypt (Simons et al., 1986). In Europe, however, after the Grande Coupure the omomyoid record is restricted to two finds from the Early Oligocene of Spain. Thus, Pseudoloris was able to survive the Eocene-Oligocene faunal turnover, as evidenced by Pseudoloris godinoti from the Suevian sites of Fonollosa and Santpedor in the Ebro Basin (Köhler and Moyà-Solà, 1999). Also, a single lower molar from the Early Oligocene of Aguatón evidences the persistence of Microchoerus in the Calatayud-Teruel Basin (Peláez-Campomanes, 2000). Therefore, at least two (Pseudoloris and Microchoerus) of the three microchoerine genera that inhabited the Iberian Peninsula during the Eocene further persisted, although rarely at best, into the Early Oligocene, constituting the only record of this group in Europe - the German fissure fillings of Ehrenstein and Harrlingen, containing microchoerine remains and originally assigned to the Early Oligocene (Schmidt-Kittler, 1971, 1977), were later considered to be Late Eocene in age (BiochroM'97, 1997). This might be related to maintenance of warmer temperatures in the Iberian Peninsula, compared to more northern areas of Europe, which would have favored the persistence of tropical to subtropical forested areas allowing the survival of some omomyoids until the Early Oligocene.

In summary, the Paleogene primate record in the Iberian Peninsula shows a great diversity of both adapoids and omomyoids in the Eocene, followed by a marked drop in the number of species in the Oligocene, in agreement with other areas of the Northern hemisphere (e.g., Fleagle, 1999). However, it is remarkable that the diversity of Eocene primates from the Iberian Peninsula has notably increased in recent years. For instance, in the last three years four new primate taxa have been described from the Iberian Eocene: the adapoids
Mazateronodon endemicus and Anchomomys frontanyensis, and the omomyoids Pseudoloris pyrenaicus and P. cuestai (Marigó et al., 2010, 2011a; Minwer-Barakat et al., 2010, 2012). Moreover, the first citation of plesiadapiforms in Spain has been reported (Marigó et al., 2012a), raising to two the mentions of this group in the Iberian Peninsula. Therefore, it seems highly probable that the diversity of Paleogene (especially Eocene) primates in the Iberian Peninsula recorded by currently available remains is even higher than recognized, and that the knowledge of this group of mammals will grow in the next few years as more detailed studies are carried out.

\subsection{Primate Iberian diversity in the Miocene and Plio-Pleistocene (Fig. 4)}

In the Iberian Peninsula, simians (anthropoids) are not recorded until well within the Miocene (late Aragonian), being represented by pliopithecoids (a Eurasian clade of stem catarrhines) as well as hominoids (apes and humans), whereas cercopithecoids (Old World monkeys) are recorded from the latest Miocene onwards.

Pliopithecoids from the Miocene of Eurasia are currently considered to be stem catarrhines on the basis of the possession of only two premolars (e.g. Andrews et al., 1996; Begun, 2002a), although it is uncertain whether they are more derived than African propliopithecoids and other stem catarrhines (Begun, 2002a). Once considered to be phylogenetically related to hylobatids, in fact they retain several primitive features indicating that they precede the cercopithecoid-hominoid split. In any case, they were the first anthropoids that dispersed into Eurasia, where they experienced an evolutionary radiation, in a continent previously devoid of other anthropoids, from the Early Miocene onwards (Begun, 2002a; Harrison, 2005). Pliopithecoids are first recorded by dionysopithecins from the Early Miocene of Asia (Harrison and $\mathrm{Gu}, 1999)$, whereas pliopithecines and crouzeliines are recorded in the Middle and Late Miocene of both Europe and Asia (Begun, 2002a; Harrison, 2005). In the Iberian Peninsula, pliopithecoids are exclusively known from the VallèsPenedès Basin (NE Spain), where they are recorded by both pliopithecines (the genus Pliopithecus) and crouzeliines (the genera Barberapithecus and Egarapithecus). This restricted geographic distribution is probably attributable to the peculiar physiographic and paleoecological conditions of the Vallès-Penedès Basin, which by the Middle and early Late Miocene was more similar to France and other Central European countries than to the inner Iberian Basins (Agustí et al., 1984; Agustí, 1990; Casanovas-Vilar and Agustí, 2007; CasanovasVilar et al., 2008). Their oldest record in Iberia (ca. 12.0 Ma; Alba et al., 2012a), however, is quite late compared to France and Central Europe (where finds occur from MN5), perhaps due to the lack of adequate outcrops from the early Middle Miocene in the Vallès-Penedès Basin. The best known pliopithecine from Iberia is Pliopithecus canmatensis, from the late Middle Miocene of several localities from the Abocador 


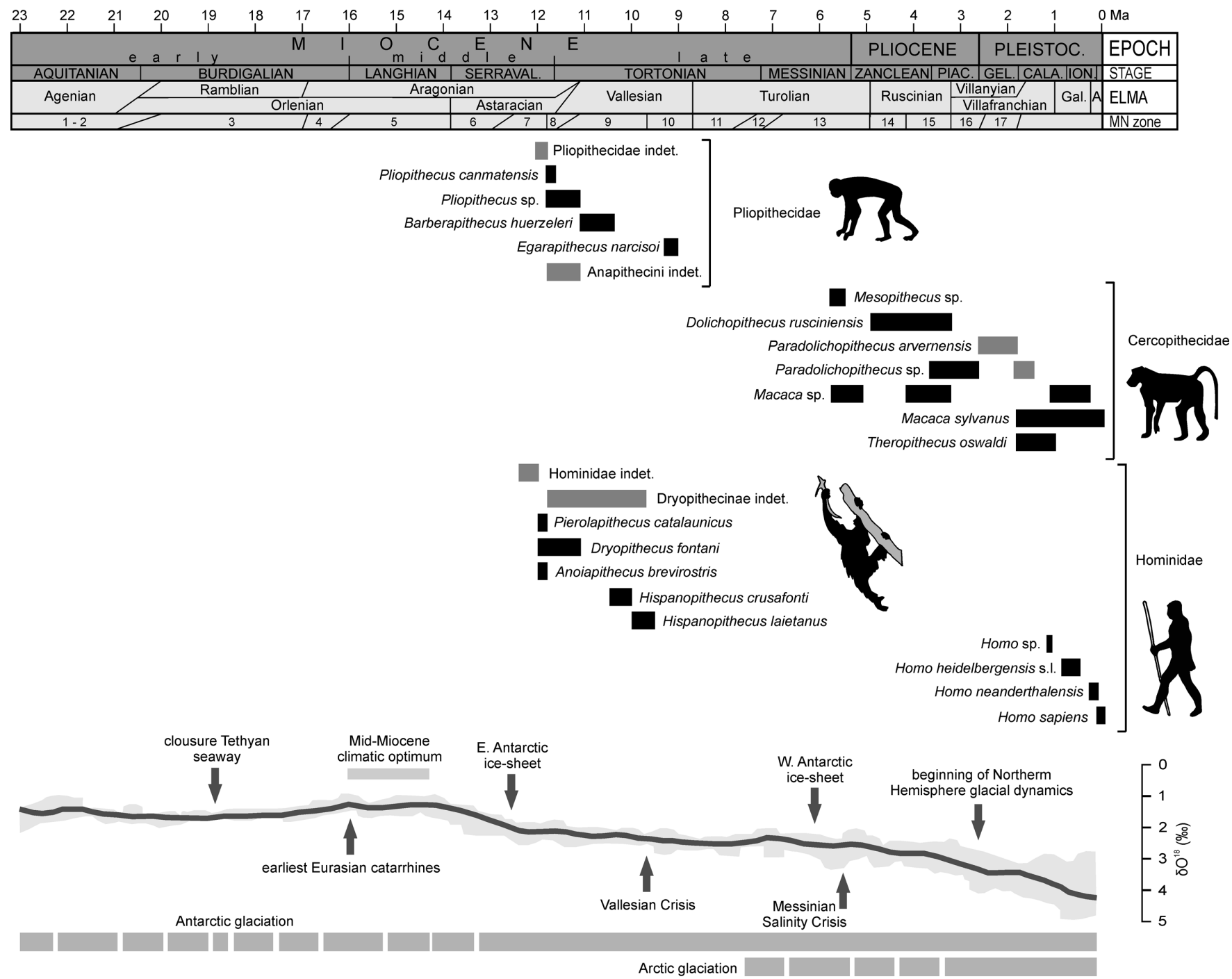

Fig. 4.- Range chart of Neogene and Quaternary Iberian primate taxa. Uncertain attributions (cf., indet.) are shown in dark gray, whereas nomina nuda and nomina dubia are not considered. The global oxygen isotope record, together with the development of ice-sheets and major climatic/ physiographic events, are also included. Age boundaries for epochs and stages are after Lourens et al. (2004). European Land Mammal Ages (ELMA) and Neogene Mammal Zones (MN) after Steiniger (1999), Agustí et al. (2001), Rook and Martínez-Navarro (2010) and Van der Meulen et al. (2011). Climatic data are taken from Zachos et al. (2001).

de Can Mata series (Alba et al., 2010d). Crouzeliines, in turn, are recorded by the anapithecins Barberapithecus huerzeleri, from the latest Middle or earliest Late Miocene of Castell de Barberà (Alba and Moyà-Solà, 2012), and Egarapithecus narcisoi, from the Late Miocene of Torrent de Febulines (Moyà-Solà et al., 2001). With an estimated age of ca. 9 Ma, Egarapithecus represents the last record of a Miocene primate in Iberia before the occurrence of cercopithecoids.

With regard to hominoids, like pliopithecoids and probably due to the same paleoecological reasons, in the Iberian Neogene they are restricted to the late Middle and early Late Miocene, further displaying a similar geographic distribution, restricted to the Vallès-Penedès Basin and to the small, intraPyrenean Seu d'Urgell Basin (Casanovas-Vilar et al., 2011). This group, including extant apes and humans, originated around the Oligocene/Miocene boundary in Africa, where they experienced a remarkable evolutionary radiation dur- ing the Early and Middle Miocene (Begun, 2007; Harrison, 2010). From the beginning of the Middle Miocene, hominoids are also recorded in Eurasia, where they diversified into a plethora of genera, most of which are considered members of the great-ape-and-human clade (Hominidae) (Begun, 2002b, 2007; Kelley, 2002; Casanovas-Vilar et al., 2011). Some authors have favored a Eurasian origin of hominids and their early divergence during the middle Miocene into pongines and hominines, followed by a later hominine dispersal event back into Africa by the late Miocene (Begun, 2002b, 2007, 2009; Begun et al., 2012). However, given the incomplete nature of the primate fossil record and the probable multidirectional nature of hominoid intercontinental dispersal and range extension events during the Middle Miocene, the place of origin of hominids cannot be currently resolved. The oldest record of Eurasian hominoids corresponds to the latest Early Miocene, just before the Langhian transgression (ca. 16.3 
Ma), but undoubted kenyapithecines such as Griphopithecus (most likely being stem hominids) are not recorded until the early Middle Miocene (ca. $14 \mathrm{Ma}$ ) (Casanovas-Vilar et al., 2011; contra Andrews and Kelley, 2007, who favor an older dating). By this time, roughly coinciding with the following Mid-Miocene Climatic Optimum (Zachos et al., 2001), the kenyapithecines of African origin apparently expanded their range into eastern Europe and Turkey, and apparently gave rise to the Eurasian radiation of hominids (Moyà-Solà et al., 2009b; Casanovas-Vilar et al., 2011; Alba, 2012).

Whereas Miocene hominoids from Asia are generally regarded as pongines (i.e., members of the orangutan clade) (Kelley, 2002; Begun, 2007), the Miocene hominoids from Europe, here included into the Dryopithecinae, have been variously considered to be stem hominids (e.g., CasanovasVilar et al., 2011), pongines (e.g., Agustí et al., 1996) or hominines (e.g., Begun, 2009; Begun et al., 2012). Despite these phylogenetic disagreements, the discoveries of Miocene hominoids from Spain that have taken place during the last two decades have provided a wealth of new information that provides several insights into hominoid evolution. The fact that the pongine Sivapithecus is first recorded at ca. 13.0-12.5 Ma in Asia (Kunimatsu et al., 2004), whereas almost simultaneously (ca. 12.3-12.2) a hominid of uncertain affinities is recorded at the other end of Eurasia in the Vallès-Penedès Basin, suggests that the initial diversification of Eurasian hominoids took place somewhat earlier, probably between 14-13 Ma (Casanovas-Vilar et al., 2011). At the same time, the cranial and dentognathic characteristics of the later, Middle Miocene Spanish dryopithecins, suggest they descended from a thick-enameled kenyapithecine ancestor (Moyà-Solà et al., 2009b; Alba et al., 2010b; Casanovas-Vilar et al., 2011). The global climatic trend towards progressive cooling and increased seasonality initiated during the middle Miocene (Zachos et al., 2001; Kovar-Eder, 2003; Mosbrugger et al., 2005) apparently favored the adaptive radiation of Eurasian hominoids (Casanovas-Vilar et al., 2011), as reflected by their widened geographic range and increased taxonomic diversity, probably as a result of the new selection pressures posed by changing ecological conditions towards more heterogeneous biotopes with increased seasonality (Begun et al., 2012). Soon after the early/late Vallesian transition (ca. 9.6 Ma), however, hominoids became extinct in Western and Central Europe, with the exception of the insular endemic Oreopithecus, which survived until ca. 7 Ma in Italy (Casanovas-Vilar et al., 2011).

In the Iberian Peninsula, dryopithecines are last recorded by Hispanopithecus at ca. $9.5 \mathrm{Ma}$, slightly predating the last occurrence of pliopithecoids ca. 9.0 Ma. The extinction of European hominoids has been linked to the vegetation changes that took place during the late Vallesian (Fortelius and Hokkanen, 2001; Agustí et al., 2003), which further resulted in the extinction of many other mammalian taxa (i.e., the Vallesian Crisis; see Agustí and Moyà-Solà, 1990; Agustí et al., 1999; Casanovas-Vilar et al., 2010). The climatic trend towards cooling and increased seasonality initiated after the Mid-Miocene Climatic Optimum (Zachos et al., 2001) apparently led to the crossing of some paleoenvironmental threshold, to which hominoids and several other mammals did not adapt (Casanovas-Vilar et al., 2011). This is further supported by the paleoenvironmental reconstruction of Can Llobateres 1 (Marmi et al., 2012), which records one of the latest occurrences of the hispanopithecin Hispanopithecus laietanus (9.6 $\mathrm{Ma}$ ) before its last apperance datum at ca. 9.5 Ma (Casanovas-Vilar et al., 2011). The vegetation from Can Llobateres 1 is consistent with a subtropical to warm-temperate climate, but evidence from other Vallès-Penedès sites indicates that such habitats would have been restricted to lowland humid areas, with warm-temperate mixed forests with a significant proportion of deciduous elements growing elsewhere (Marmi et al., 2012). Following global climatic changes (Zachos et $a l ., 2001)$, the progressive disappearance of tropical and subtropical plants - providing a continuous supply of fruits all year long-, and the concomitant increasing dominance by deciduous trees, may have resulted in the lack of adequate trophic resources for both hominoids and pliopithecoids during the unfavorable season, ultimately leading to their extinction not only in Iberia but also in the rest of Europe and most of Asia.

The same global changes that, in most of Eurasia, drove the extinction of pliopithecoids and hominoids, probably favored the dispersal and diversification of monkeys. By the Early and Middle Miocene, cercopithecoids were already distinct but much less diverse than hominoids, but from the Late Miocene onwards, their disparity, geographic distribution and paleodiversity increased dramatically (Szalay and Delson, 1979; Jablonski, 2002; Eronen and Rook, 2004; Jablonski and Frost, 2010). This might be related to different dietary adaptations between both groups (Andrews, 1981) and/or to differences in life-history parameters between them (Jablonski and Kelley, 1997). Such factors likely conditioned differently the evolutionary responses of cercopithecoids and hominoids to the changing climatic conditions initiated by the Middle Miocene, but most strongly expressed during the latest Miocene and the Pliocene. Thus, both colobines and cercopithecines possess specific dietary adaptations for more efficient folivory and/or consumption of unripe fruits compared to hominoids (Andrews, 1981), thereby enabling the former to more easily thrive when the ripe fruits habitually consumed by most hominoids are scarce. Moreover, hominoids display a low life-history profile, suitable for the tropical to subtropical forested conditions with low seasonality of the African Early Miocene, providing an abundant provision of high-quality food resources; in contrast, the faster life history of cercopithecoids is more suitable for the highly seasonal environments that prevailed in Europe by the latest Miocene, thus enabling them to thrive in a wider range of habitats compared to hominoids (Jablonski and Kelley, 1997; Eronen and Rook, 2004). Hence, many latest Miocene and Pliocene cercopithecoid lineages occupied less heavily for- 
ested and more seasonal habitats than the preceding hominoids. Two distinct families of cercopithecoids are usually distinguished: crown cercopithecoids are classified into a single family, Cercopithecidae, with two distinct subfamilies (Colobinae and Cercopithecinae), distinguished at the family level by some authors (e.g., Jablonski, 2002); whereas stem cercopithecoids are classified into another, extinct family (the Victoriapithecidae). In the Iberian Peninsula, both cercopithecines and colobines are recorded. Colobines are represented by Mesopithecus in the latest Miocene, and by its presumed descendant, Dolichopithecus, during the Pliocene. Cercopithecines, in turn, are recorded by Macaca, from the latest Miocene onwards, as well as by Paradolichopithecus from the Late Pliocene and Early Pleistocene, and Theropithecus from the Early Pleistocene.

Until recently, the colobine Mesopithecus had not been recorded in the Iberian Peninsula, but recent finds (Montoya et al., 2006; Guillén Castejón, 2010) have shown that this was merely an artifact of the record. At Venta del Moro, Mesopithecus is recorded ca. 5.8-5.5 Ma (Montoya et al., 2002, 2006), thus conclusively indicating that Mesopithecus dispersed into westernmost Europe by at least the latest Turolian (MN13). Similarly, Macaca is recorded by ca. 6.1-5.3 Ma at Almenara-Casablanca M (Köhler et al., 2000). The dispersal of these semi-terrestrial and oportunistic genera into the Iberian Peninsula must be understood within the framework of the significant faunal turnovers that took place in Europe by this time (van der Made, 2006; Agustí et al., 2006), apparently before the first evaporitic cycle of the Messinian Salinity Crisis. This event implied the clousure of the Gibraltar strait, ultimately leading to the total (or almost complete) desiccation of the Mediterranean between 5.5-5.3 Ma (Hsü et al., 1973). At the same time, this created an African-European connection that allowed the dispersal of certain mammal taxa including hippopotamids, gerbils, crested rats and likely cercopithecines as well (Agustí et al., 2006).

Subsequent dispersal and range extension events took place into the Iberian Peninsula during the Pleistocene, as reflected by the record of the gelada Theropithecus at ca. $1.0 \mathrm{Ma}$ in Cueva Victoria (Gibert et al., 1995), and that of early Homo from ca. 1.2 Ma (Carbonell et al., 2008; Bermúdez de Castro et al., 2011, 2012b) onwards. Throughout the remaining Pleistocene, humans and macaques were apparently the only primates that managed to survive in the Iberian Peninsula and the rest of Europe, being (for different biological reasons) well suited to survive under the changing paleoenvironmental conditions (with marked glacial cycles) of the Pleistocene (Eronen and Rook, 2004). In the case of European macaques, they apparently extended their geographical range much farther northwards during the interglacials, and retreated into their Mediterranean refugia during glacials, although they ultimately became locality extinct due to their inability to tolerate the most severe stage of the last glaciation (Fooden, 2007), being last recorded in Iberia by ca. $80 \mathrm{ka}$ (Castaños et $a l ., 2011)$. With regard to humans, there is the possibility that different dispersal events of early humans into the Iberian Peninsula and Western Eurasia in general took place during the Pleistocene (Bermúdez de Castro and Martinón-Torres, 2013), thus being still uncertain (see discussion in MadurellMalapeira et al., 2012) whether humans continuously occupied the Iberian Peninsula between their early record at ca. 1.2 Ma and their subsequent record at ca. $0.88-0.78 \mathrm{Ma}$ (Carbonell et al., 1995; Bermúdez de Castro, 1997).

\section{Acknowledgments}

This work has been funded by the Spanish Ministerio de Ciencia e Innovación (CGL2011-27343; CGL2011-28681; CGL2010-21672/BTE; JCI-2010-08241 to I.C.-V.; RYC2009-04533 to D.M.A.); the Generalitat de Catalunya (2009 SGR 754, GRC, predoctoral fellowship 2010FIB176 to J.M., and travel grants 2010BE00758, 2011BE100009 and 2011CTP00011 to J.M.); and the SYNTHESYS Project (FRTAF-80 and FR-TAF-1735 to J.M.; http://www.synthesys. info/), which is financed by the European Community Research Infrastructure Action under the FP6 "Structuring the European Research Area" Programme. We thank the reviewers Eric Delson and Peter Andrews, whose comments helped to improve a previous version of this paper.

\section{References}

Aguirre, E., Fuentes, C. (1969): Los vertebrados fósiles de Torralba y Ambrona. In: Études sur le Quaternaire dans le monde. VIII Congrés INQUA, 433-437.

Aguirre, E., Soto, E. (1974): Nuevo fósil de Cercopitécido en el Pleistoceno inferior de Puebla de Valverde (Teruel). Estudios Geológicos 30, 213-217.

Aguirre, E., Soto, E. (1978): Paradolichopithecus in La Puebla de Valverde, Spain: Cercopithecoidea in European Neogene stratigraphy. Journal of Human Evolution 7, 559-565. doi: 10.1016/S00472484(78)80042-6

Aguirre Enríquez, E. (2007): Neandertales ibéricos: habitat, subsistencia, extinción. Revista de la Real Academia de Ciencias Exactas, Físicas y Naturales (España) 101, 203-210.

Agustí, J. (1990): The Miocene rodent succession in Eastern Spain: a zoogeographical appraisal. In: E.H. Lindsay, V. Fahlbusch, P. Mein (eds.), European Neogene Mammal Chronology. Plenum Press, New York: 375-404.

Agustí, J., Moyà-Solà, S. (1990): Mammal extinctions in the Vallesian (Upper Miocene). Lecture Notes in Earth Sciences 30/1990, 425-432. doi: $10.1007 / \mathrm{BFb} 0011163$

Agustí, J., Moyà-Solà, S., Gibert, J. (1984): Mammal distribution dynamics in the eastern margin of the Iberian Peninsula during the Miocene. Paléobiologie Continentale 14, 33-46.

Agustí, J., Köhler, M., Moyà-Solà, S., Cabrera, L., Garcés, M., Parés, J.M. (1996): Can Llobateres: the pattern and timing of the Vallesian hominoid radiation reconsidered. Journal of Human Evolution 31, 143-155. doi: 10.1006/jhev.1996.0055

Agustí, J., Cabrera, L., Garcés, M., Llenas, M. (1999): Mammal turnover and global climate change in the late Miocene terrestrial record of the Vallès-Penedès Basin (NE Spain). In: J. Agustí, L. Rook and P. Andrews (eds.), Hominoid Evolution and climatic change in Europe. Volume 1: The Evolution of Neogene Terrestrial Ecosystems in Europe. Cambridge University Press, Cambridge: 390-412. 
Agustí, J., Sanz de Siria, A., Garcés, M. (2003): Explaining the end of the hominoid experiment in Europe. Journal of Human Evolution 45, 145-153. doi: 10.1016/S0047-2484(03)00091-5

Agustí, J., Garcés, M., Krijgsman, W. (2006): Evidence for AfricanIberian exchanges during the Messinian in the Spanish mammalian record. Palaeogeography, Palaeoclimatolology, Palaeoecology 238, 5-14. doi: 10.1016/j.palaeo.2006.03.013

Alba, D.M. (2012): Fossil apes from the Vallès-Penedès Basin. Evolutionary Anthropology 21, 254-269. doi: 10.1002/evan.21312

Alba, D.M., Moyà-Solà, S. (2012a): A new pliopithecid genus (Primates: Pliopithecoidea) from Castell de Barberà (Vallès-Penedès Basin, Catalonia, Spain). American Journal of Physical Anthropology 147, 88-112. doi:10.1002/ajpa.21630

Alba, D.M., Moyà-Solà, S. (2012b, published online): On the identity of a hominoid male upper canine from the Vallès-Penedès Basin figured by Pickford (2012). Estudios Geológicos. doi: 10.3989/ egeol.40900.180

Alba, D.M., Moyà-Solà, S., Madurell, J., Aurell, J. (2008): Dentognathic remains of Macaca (Primates, Cercopithecidae) from the late early Pleistocene of Terrassa (Catalonia, Spain). Journal of Human Evolution 55, 1160-1163. doi:10.1016/j.jhevol.2008.05.006

Alba, D.M., Almécija, S., Moyà-Solà, S. (2010a): Locomotor inferences in Pierolapithecus and Hispanopithecus: Reply to Deane and Begun (2008). Journal of Human Evolution 59, 143-149. doi:10.1016/j.jhevol.2010.02.002

Alba, D.M., Fortuny, J., Moyà-Solà, S. (2010b): Enamel thickness in Middle Miocene great apes Anoiapithecus, Pierolapithecus and Dryopithecus. Proceedings of the Royal Society B 277, 2237-2245. doi:10.1098/rspb.2010.0218

Alba, D.M., Moyà-Solà, S., Almécija, S. (2010c): L'estudi dels primats del Neogen i el Quaternari de Catalunya. In: Història Natural dels Països Catalans, vol. 16. Suplement: Fauna i flora. Enciclopèdia Catalana, Barcelona: 424-427.

Alba, D.M., Moyà-Solà, S., Malgosa, A., Casanovas-Vilar, I., Robles, J.M., Almécija, S., Galindo, J., Rotgers, C., Bertó Mengual, J.V. (2010d): A new species of Pliopithecus Gervais, 1849 (Primates: Pliopithecidae) from the Middle Miocene (MN8) of Abocador de Can Mata (els Hostalets de Pierola, Catalonia, Spain). American Journal of Physical Anthropology 141, 52-75. doi:10.1002/ajpa.21114

Alba, D.M., Moyà-Solà, S., Almécija, S. (2011a): A partial hominoid humerus from the middle Miocene of Castell de Barberà (Vallès-Penedès Basin, Catalonia, Spain). American Journal of Physical Anthropology 144, 365-381. doi:10.1002/ajpa.21417

Alba, D.M., Almécija, S., Moyà-Solà, S., Casanovas-Vilar, I., Méndez, J.M. (2011b): A new partial skeleton of the fossil great ape Hispanopithecus (Primates: Hominidae) from the Late Miocene of Can Feu (Vallès-Penedès Basin, NE Iberian Peninsula) [Abstract]. Journal of Vertebrate Paleontology 71st Annual Meeting Society of Vertebrate Paleontology, 60.

Alba, D.M., Carlos Calero, J.A., Mancheño, M.Á., Montoya, P., Morales, J., Rook, L. (2011c): Fossil remains of Macaca sylvanus florentina (Cocchi, 1872) (Primates, Cercopithecidae) from the Early Pleistocene of Quibas (Murcia, Spain). Journal of Human Evolution 61, 703-718. doi:10.1016/j.jhevol.2011.09.003

Alba, D.M., Casanovas-Vilar, I., Robles, J.M., Moyà-Solà, S. (2011d): Parada 3. El Aragoniense superior y la transición con el Vallesiense: Can Mata y la exposición paleontological de els Hostalets de Pierola. Paleontologia i Evolució memòria especial núm. 6: 219-222.

Alba, D.M., Moyà-Solà, S., Robles, J.M., Galindo, J. (2012a): Brief Communication: The oldest pliopithecid record in the Iberian Peninsula based on new material from the Vallès-Penedès Basin. American Journal of Physical Anthropology 147, 135-140. doi:10.1002/ ajpa.21631

Alba, D.M., Casanovas-Vilar, I., Almécija, S., Robles, J.M., Arias-Mar- torell, J., Moyà-Solà, S. (2012b). New dental hominoid remains from the Late Miocene locality of Can Llobateres 1 (Vallès-Penedès Basin, Catalonia, Spain) [Abstract]. American Journal of Physical Anthropology 147, S54, 81.

Alba, D. M., Casanovas-Vilar, I., Almécija, S., Robles, J.M., Arias-Martorell, J., Moyà-Solà, S. (2012c): New dental remains of Hispanopithecus laietanus (Primates: Hominidae) from Can Llobateres 1 and the taxonomy of Late Miocene hominoids from the Vallès-Penedès Basin (NE Iberian Peninsula). Journal of Human Evolution 63, 231246. doi:10.1016/j.jhevol.2012.05.009

Alba, D. M., Almécija, S., Casanovas-Vilar, I., Méndez, J.M., MoyàSolà, S. (2012d): A partial skeleton of Hispanopithecus laietanus from Can Feu and the mosaic evolution of crown-hominoid positional behaviors. PLoS ONE 7, e39617. doi:10.1371/journal.pone.0039617

Alba, D.M., Fortuny, J., Pérez de los Ríos, M., Zanolli, C., Almécija, S., Casanovas-Vilar, I., Robles, J.M., Moyà-Solà, S. (2013): New dental remains of Anoiapithecus and the first appearance datum of hominoids in the Iberian Peninsula. Journal of Human Evolution 65, 573 584. doi: 10.1016/j.jhevol.2013.07.003

Albright, L.B. III (2005): Ekgmowechashala (Mammalia, ?Primates) from the Gulf coastal plain. Bulletin of the Florida Museum of Natural History 45, 355-361.

Alférez, F., Molero, G., Maldonado, E., Bustos, V., Brea, P., Buitrago, A.M. (1982): Descubrimiento del primer yacimiento cuaternario (Riss-Würm) de vertebrados con restos humanos en la provincia de Madrid (Pinilla del Valle). Coloquios de Paleontología 37, 15-32.

Alférez, F., Molero, G., Maldonado, E. (1985): Estudio preliminar del úrsido del yacimiento del Cuaternario medio de Pinilla del Valle (Madrid) (1). Coloquios de Paleontología 40, 59-67.

Almécija, S., Alba, D.M., Moyà-Solà, S., Köhler, M. (2007): Orang-like manual adaptations in the fossil hominoid Hispanopithecus laietanus: first steps towards great ape suspensory behaviours. Proceedings of the Royal Society B 274, 2375-2384. doi:10.1098/rspb.2007.0750

Almécija, S., Alba, D.M., Moyà-Solà, S. (2009): Pierolapithecus and the functional morphology of Miocene ape hand phalanges: paleobiological and evolutionary implications. Journal of Human Evolution 57, 284-297. doi:10.1016/j.jhevol.2009.02.008

Almécija, S., Alba, D.M., Moyà-Solà, S. (2011): Large-hominoid remains from the Middle Miocene locality of Castell de Barberà (Vallès-Penedès Basin, Catalonia, Spain). American Journal of Physical Anthropology 144, S52, 74.

Almécija, S., Alba, D.M., Moyà-Solà, S. (2012): The thumb of Miocene apes: new insights from Castell de Barberà (Catalonia, Spain). American Journal of Physical Anthropology 148, 436-450. doi: 10.1002/ ajpa. 22071

Andrews, P. (1981): Species diversity and diet in monkeys and apes during the Miocene. In: C.B. Stringer (ed.), Aspects of Human Evolution. Taylor and Francis, London: 25-61.

Andrews P, Kelley J. (2007): Middle Miocene dispersals of apes. Folia Primatologica 78, 328-343. doi: 10.1159/000105148

Andrews, P., Harrison, T., Delson, E., Bernor, R.L., Martin, L. (1996): Distribution and biochronology of European and Southwest Asian Miocene catarrhines. In: R.L. Bernor, V. Fahlbusch, H.-W. Mittmann (eds.), The Evolution of Western Eurasian Neogene Mammal faunas. Columbia University Press, New York: 168-207.

Antunes, M.T. (1981): As areias e argilas de Silveirinha. II - Aspectos paleontológicos. Memorias e Noticias 91-92, 245-267.

Antunes, M.T., Rusell, D.E. (1981): Le gisement de Silveirinha (Bas Mondego, Portugal): la plus ancienne faune de vertébrés éocènes connue en Europe. Comptes Rendus de l'Académie des Sciences de Paris 293, 1099-1102.

Antunes, M.T., Santinho Cunha, A. (1992): Neanderthalian remains from Figueira Brava cave, Portugal. Geobios 25, 681-692.

Antunes, M.T., Casanovas, M.L., Cuesta, M.A., Checa, L., Santafé, J.V., 
Agustí, J. (1997): Eocene mammals from Iberian Peninsula. Mémoires et Travaux de E.P.H.E. de l'Institut de Montpellier 21, 337-352.

Ardito, G., Mottura, A. (1987): An overview of the geographic and chronologic distribution of West European cercopithecoids. Human Evolution 2, 29-45.

Arsuaga, J.L., Bermúdez de Castro, J.M. (1984): Estudio de los restos humanos del yacimiento de la Cova del Tossal de la Font (Villafamés, Castellón). Cuadernos de Prehistoria y Arqueología Castellonenses 10, 19-34.

Arsuaga, J.L., Gracia, A., Martínez, I., Bermúdez de Castro, J.M., Rosas, A., Villaverde, V., Fumanal, M.P. (1989): The human remains from Cova Negra (Valencia, Spain) and their place in European Pleistocene human evolution. Journal of Human Evolution 18, 55-92.

Arsuaga, J.L., Martínez, I., Gracia, A., Carretero, J.M., Carbonell, E. (1993): Three new human skulls from the Sima de los Huesos Middle Pleistocene site in Sierra de Atapuerca, Spain. Nature 362, 534-537.

Arsuaga, J.L., Martínez, I., Gracia, A., Lorenzo, C. (1997): The Sima de los Huesos crania (Sierra de Atapuerca, Spain). A comparative study. Journal of Human Evolution 33, 219-281.

Arsuaga, J.L., Martínez, I., Lorenzo, C., Gracia, A., Muñoz, A., Alonso, O., Gallego, J. (1999): The human cranial remains from Gran Dolina Lower Pleistocene site (Sierra de Atapuerca, Spain). Journal of Human Evolution 37, 431-457.

Arsuaga, J.L., Villaverde, V., Quam, R., Gracia, A., Lorenzo, C., Martínez, I., Carretero, J. M. (2002): The Gravettian occipital bone from the site of Malladetes (Barx, Valencia, Spain). Journal of Human Evolution 43, 381-393. doi:10.1006/jhev.2002.0579

Arsuaga, J.L., Villaverde, V., Quam, R., Martínez, I., Carretero, J.M., Lorenzo, C., Gracia, A. (2007): New Neandertal remains from Cova Negra (Valencia, Spain). Journal of Human Evolution 52, 31-38. doi:10.1016/j.jhevol.2006.07.011

Arsuaga, J. L., Fernández Peris, J., Gracia-Téllez, A., Quam, R., Carretero, J.M., Barciela González, V., Blasco, R., Cuartero, F., Sañudo, P. (2012): Fossil human remains from Bolomor Cave (Valencia, Spain). Journal of Human Evolution 62, 629-639. doi:10.1016/j. jhevol.2012.02.002

Badiola, A., Checa, L., Cuesta, M.A., Quer, R., Hooker, J.J., Astibia, H. (2009): The role of new Iberian finds in understanding European Eocene mammalian paleobiogeography. Geologica Acta 7, 243-258. doi:10.1344/105.000000281

Barroso, C. (ed.) (2003): El Pleistoceno Superior de la Cueva del Boquete de Zafarraya, Junta de Andalucía, Sevilla: 520 p.

Begun, D.R. (1992): Dryopithecus crusafonti sp. nov., a new Miocene hominoid species from Can Ponsic (Northeastern Spain). American Journal of Physical Anthropology 87, 291-309.

Begun, D.R. (2002a): The Pliopithecoidea. In: W.C. Hartwig (ed.), The primate fossil record. Cambridge University Press, Cambridge: $221-$ 240.

Begun, D.R. (2002b): European hominoids. In: W.C. Hartwig (ed.), The primate fossil record. Cambridge University Press, Cambridge: 339368.

Begun, D.R. (2007): Fossil record of Miocene hominoids. In: Henke, W., Tattersall, I. (eds.), Handbook of Paleoanthropology. Heidelberg, Springer Verlag: 921-977.

Begun, D.R. (2009): Dryopithecins, Darwin, de Bonis, and the European origin of the African apes and human clade. Geodiversitas 31, 789-816. doi:10.5252/g2009n4a789

Begun, D.R., Ward, C.V. (2005): Comment on "Pierolapithecus catalaunicus, a new Middle Miocene great ape from Spain". Science 208, 203c. doi:10.1126/science.1108139

Begun, D.R., Moyá-Sola, S., Kohler, M. (1990): New Miocene hominoid specimens from Can Llobateres (Vallès Penedès, Spain) and their geological and paleoecological context. Journal of Human Evolution 19, 255-268.
Begun, D.R., Nargolwalla, M.C., Kordos, L. (2012): European Miocene hominids and the origin of the African ape and human clade. Evolutionary Anthropology 21, 10-23. doi:10.1002/evan.20329

Bermúdez de Castro, J.M., Martinón-Torres, M. (2013): A new model for the evolution of the human Pleistocene populations of Europe. Quaternary International, 295, 102-111. doi:10.1016/j.quaint.2012.02.036

Bermúdez de Castro, J.M., Arsuaga, J.L., Carbonell, E., Rosas, E., Martínez, I., Mosquera, M. (1997): A hominid from the Lower Pleistocene of Atapuerca, Spain: Possible ancestor to neandertals and modern humans. Science 276, 1392-1395.

Bermúdez de Castro, J.M., Pérez-González, A., Martinón-Torres, M., Gómez-Robles, A., Rosell, J., Prado, L., Sarmiento, S., Carbonell, E. (2008): A new early Pleistocene hominin mandible from AtapuercaTD6, Spain. Journal of Human Evolution 55, 729-735. doi:10.1073/ pnas.0501841102

Bermúdez de Castro, J.M., Martinón-Torres, M., Gómez-Robles, A., Prado-Simón, L., Martín-Francés, L., Lapresa, M., Olejnickzak, A., Carbonell, E. (2011): Early Pleistocene human mandible from Sima del Elefante (TE) cave site in Sierra de Atapuerca (Spain): A comparative morphological study. Journal of Human Evolution 61, 12-25. doi:10.1016/j.jhevol.2011.03.005

Bermúdez de Castro, J. M., Carretero, J.M., García-González, R., Rodríguez-García, L., Martinón-Torres, M., Rosell, J., Blasco, R., MartínFrancés, L., Modesto, M., Carbonell, E. (2012a): Early Pleistocene human humeri from the Gran Dolina-TD6 site (Sierra de Atapuerca, Spain). American Journal of Physical Anthropology 147, 604-617. doi: 10.1002/ajpa.22020

Bermúdez de Castro, J.M., Martinón-Torres, M. (2012b, published online): A new model for the evolution of the human Pleistocene populations of Europe. Quaternary International. doi:10.1016/j. quaint.2012.02.036

BiochroM'97 (1997): Synthèses et tableaux de corrélations. In: J.-P. Aguilar, S. Legendre, J. Michaux (Eds.) Actes du Congrès Biochrom. Mémoires et Travaux EPHE Institut Montpellier, 21: 769-805.

Bloch, J.I., Silcox, M.T., Boyer, D.M., Sargis, E.J. (2007): New Paleocene skeletons and the relationship of plesiadapiforms to crown-clade Primates. Proceedings of the National Academy of Sciences, U.S.A., 104, 1159-1164.

Busquets, P., Ramos-Guerrero, E., Moyà, S., Agustí, J., Colombo, F., Checa, L., Köhler, M. (1992): La Formación de Bellmunt (Unidad del Cadí, Pirineo oriental): aportaciones bioestratigráficas de los sistemas lacustres y palustres asociados. Acta Geológica Hispánica 27, 109-116.

Cameron, D.W. (1997): A revised systematic scheme for the Eurasian Miocene fossil Hominidae. Journal of Human Evolution 33, 449-477. doi: 10.1006/jhev.1997.0145

Cameron, D.W. (1999): The single species hypothesis and Hispanopithecus fossils from the Vallés Penedés Basin, Spain. Zeitschrift für Morphologie und Anthropologie 82, 159-186.

Carbonell, E., Bermúdez de Castro, J.M., Arsuaga, J.L., Díez, J.C., Rosas, A., Cuenca-Bescós, G., Sala, R., Mosquera, M. (1995): Lower Pleistocene hominids and artifacts from Atapuerca-TD6 (Spain). Science 269, 826-830. doi: 10.1126/science.7638598

Carbonell, E., Bermúdez de Castro, J.M., Arsuaga, J.L., Allue, E., Bastir, M., Benito, A., Cáceres, I., Canals, T., Díez, J.C., van der Made, J., Mosquera, M., Ollé, A., Pérez-González, A., Rodríguez, J., Rodríguez, X.P., Rosas, A., Rosell, J., Sala, R., Vallverdú, J., Vergés, J.M. (2005): An Early Pleistocene hominin mandible from AtapuercaTD6, Spain. Proceedings of the National Academy of Sciences, U.S.A. 102, 5674-5678. doi: 10.1073/pnas.0501841102

Carbonell, E., Bermúdez de Castro, J.M., Parés, J.M., Pérez-González, A., Cuenca-Bescós, G., Ollé, A., Mosquera, M., Huguet, R., van der Made, J., Rosas, A., Sala, R., Vallverdú, J., García, N., Granger, D.E., Martinón-Torres, M., Rodríguez, X.P., Stock, G.M., Vergès, J.M., 
Allué, E., Burjachs, F., Cáceres, I., Canals, A., Benito, A., Díez, C., Lozano, M., Mateos, A., Navazo, M., Rodríguez, J., Rosell, J., Arsuaga, J.L. (2008): The first hominin of Europe. Nature 452, 465-469. doi: $10.1038 /$ nature 06815

Carretero, J.M., Lorenzo, C., Arsuaga, J.L. (1999): Axial and apendicular skeleton of Homo antecessor. Journal of Human Evolution 37, 459-499. doi: 10.1006/jhev.1999.0342

Casanovas Cladellas, M.L. (1975): Estratigrafía y paleontología del yacimiento ludiense de Roc de Santa (área del Noguera-Pallaresa) (Tesis doctoral - resumen). Paleontología y Evolución 10, 1-158.

Casanovas, M.L. (1998): Antecedentes de los estudios paleontológicos en el Eoceno Superior de la Pobla de Segur. In: López-Martínez, N., Civis, J. and Daams, R. (eds.), Geología y Paleontología del Eoceno de la Pobla de Segur, Universitat de Lleida, Lleida: 41-47.

Casanovas-Vilar, I., Agustí, J. (2007): Ecogeographical stability and climate forcing in the Late Miocene (Vallesian) rodent record of Spain. Palaeogography, Palaeoclimatology, Palaeoecology 248, 169-189. doi: 10.1016/j.palaeo.2006.12.002

Casanovas-Vilar, I., Alba, D.M., Moyà-Solà, S., Galindo, J., Cabrera, L., Garcés, M., Furió, M., Robles, J.M., Köhler, M., Angelone, C. (2008): Biochronological, taphonomical and paleoenvironmental background of the fossil great ape Pierolapithecus catalaunicus (Primates, Hominidae). Journal of Human Evolution 55, 589-603. doi: 10.1016/j. jhevol.2008.05.004

Casanovas-Vilar, I., García-Paredes, I., Alba, D.M., Van den Hoek Ostende, L., Moyà-Solà, S. (2010): The European Far West: Miocene mammal isolation, diversity and turnover in the Iberian Peninsula. Journal of Biogeography 37, 1079-1093. doi: 10.1111/j.13652699.2010.02286.x

Casanovas-Vilar, I., Alba, D.M., Garcés, M., Robles, J.M., Moyà-Solà, S. (2011): Updated chronology for the Miocene hominoid radiation in Western Eurasia. Proceedings of the National Academy of Sciences, U.S.A. 108, 5554-5559. doi: 10.1073/pnas.1018562108

Castaños, P., Murelaga, X., Arrizabalaga, A., Iriarte, M.-J. (2011): First evidence of Macaca sylvanus (Primates, Cercopithecidae) from the Late Pleistocene of Lezetxiki II cave (Basque Country, Spain). Journal of Human Evolution 60, 816-820. doi: 10.1016/j.jhevol.2011.01.011

Checa Soler, L., Rius Font, L. (2003): Intervenció paleontològica a l'EDAR Sabadell-Riu Ripoll (Can Llobateres, Sabadell, Vallès Occidental). Tribuna d'Arqueologia 1999-2000, 7-22.

Collinson, M.E., Hooker, J.J. (2003): Paleogene vegetation of Eurasia: framework for mammalian faunas. Deinsea 10, 41-83.

Crusafont Pairó, M. (1958a): Los mamíferos del Luteciense superior de Capella (Huesca). Notas y Comunicaciones del Instituto Geológico y Minero de España, 50: 257-279.

Crusafont Pairó, M. (1958b): Nuevo hallazgo del póngido vallesiense Hispanopithecus. Boletín Informativo del Instituto de Paleontología de Sabadell 13-14, 37-41, 6-8.

Crusafont Pairó, M. (1965a): El desarrollo de los caninos en algunos Driopitécidos del Vallesiense en Cataluña. Notas y Comunicaciones del Instituto Geológico y Minero de España 80, 179-192.

Crusafont Pairó, M. (1965b): Los mamíferos, y en especial los primates, del Eoceno Prepirenaico. Notas y Comunicaciones del Instituto Geológico y Minero de España 78, 159-166.

Crusafont-Pairó, M. (1967): Sur quelques Prosimiens de l'Eocène de la région préaxiale pyrénaique et un essai provisoire de reclassification. Colloques Internationals du C.N.R.S. 163, 611-632.

Crusafont Pairó, M. (1973): El nombre genérico Agerinia sustituyendo a Agerina. Acta Geológica Hispánica 8, 150.

Crusafont-Pairó, M. (1978): El gibón fósil (Pliopithecus) del Vindoboniense terminal del Vallès. Paleontología y Evolución 13, 11-12.

Crusafont, Pairó M., Golpe Posse, J.M. (1968): Los nuevos yacimientos de mamíferos del Eoceno español. Boletín Geológico y Minero 79, 341-353.
Crusafont-Pairó, M., Golpe-Posse, J.M. (1973a): New pongids from the Miocene of Vallès Penedès Basin (Catalonia, Spain). Journal of Human Evolution 2, 17-23. doi: 10.1016/0047-2484(73)90092-4

Crusafont Pairó, M. Golpe-Posse, J.M. (1973b): Yacimientos del Eoceno prepirenaico (nuevas localidades del Cuisiense). Acta Geológica Hispánica 7, 145-147.

Crusafont-Pairó, M., Golpe-Posse, J.M. (1974): Primates fósiles de España. In: Miscellanea Alcobé. Universidad de Barcelona, Barcelona: 29-44.

Crusafont-Pairó, M., Golpe Posse, J.M. (1975): Les prosimiens de l'Éocène de la région préaxiale pyrénaïque. II. Adapidae. Problèmes actuels de Paléntologie. Colloques Internationals du C.N.R.S. 218, 851-859.

Crusafont-Pairó, M., Golpe-Posse, J.M. (1981): Estudio de la dentición inferior del primer pliopitécido hallado en España (Vindoboniense terminal de Castell de Barberà, Cataluña, España). Butlletí Informatiu de l'Institut de Paleontologia de Sabadell 13, 25-38.

Crusafont Pairó, M., Golpe Posse, J.M. (1982): Los Pliopitécidos en España. Coloquios de Paleontología 37, 41-46.

Crusafont-Pairó, M., Golpe-Posse, J.M. (1984): Nuevo hallazgo de macaco en Cova Bonica (Gavà). Acta Geológica Hispánica 19, 29-32.

Crusafont-Pairó, M., Hürzeler, J. (1961): Les pongidés fossiles d'Espagne. Comptes Rendus de l'Académie des Sciences de Paris 252, 582-584.

Crusafont-Pairó, M., Hürzeler, J. (1969): Catálogo comentado de los póngidos fósiles de España. Acta Geológica Hispánica 4, 44-48.

Cuesta, M.A. (1991): Perisodáctilos del Eoceno de la Cuenca del Duero. Universidad de Salamanca, unpublished Ph.D. dissertation, $322 \mathrm{p}$.

Daura, J., Sanz, M., Subirá, M.E., Quam, R., Fullola, J.M., Arsuaga, J.L. (2005): A Neandertal mandible from the Cova del Gegant (Sitges, Barcelona, Spain). Journal of Human Evolution 49, 56-70. doi: 10.1016/j.jhevol.2005.03.004

Dean, M.C., Stringer, C.B., Bromage, T.G. (1986): Age at death of the Neanderthal child from Devil's Tower, Gibraltar and the implications for studies of general growth and development in Neanderthals. American Journal of Physical Anthropology 70, 301-309. doi: 10.1002/ ajpa. 1330700305

Deane, A.S., Begun, D.R. (2008): Broken fingers: retesting locomotor hypotheses for fossil hominoids using fragmentary proximal phalanges and high-resolution polynomial curve fitting (HR-PCF). Journal of Human Evolution 55, 691-701. doi: 10.1016/j.jhevol.2008.05.005

Deane, A.S., Begun, D.R. (2010): Pierolapithecus locomotor adaptations: a reply to Alba et al.'s comment on Deane and Begun (2008). Journal of Human Evolution 59, 150-154. doi: 10.1016/j.jhevol.2010.04.003

Delson, E. (1971): Estudio preliminar de unos restos de simios pliocénicos procedentes de "Cova Bonica" (Gavá) (Prov. Barcelona). Acta Geológica Hispánica 6, 54-57.

Delson, E. (1973): Fossil colobine monkeys of the Circum-Mediterranean region and the evolutionary history of the Cercopithecidae (Primates, Mammalia). Ph.D. Dissertation, Columbia University.

Delson, E. (1974): Preliminary review of cercopithecid distribution in the Circum Mediterranean region. Memoires du Bureau de Recherches Geologiques et Minieres (France) 78, 131-135.

Delson, E. (1977): Catarrhine phylogeny and clasification: Principles, methods and comments. Journal of Human Evolution 6, 433-459. doi: 10.1016/S0047-2484(77)80057-2

Delson, E. (1980): Fossil macaques, phyletic relationships and a scenario of deployment. In: Lindburg, D.E. (ed.), The Macaques. Studies in Ecology, Behavior and Evolution. Van Nostrand, New York: 10-30.

Delson, E. (1993): Theropithecus fossils from Africa and India and the taxonomy of the genus. In: N. Jablonski (ed), Theropithecus: Rise and Fall of a Primate Genus. Cambridge University Press, Cambridge: 157-189. 
Duarte, C., Maurício, J., Pettitt, P.B., Souto, P., Trinkaus, E., van der Plicht, H., Zilhão, J. (1999): The early Upper Paleolithic human skeleton from the Abrigo do Lagar Velho (Portugal) and modern human emergence in Iberia. Proceedings of the National Academy of Sciences, U.S.A. 96, 7604-7609. doi: 10.1073/pnas.96.13.7604

Duval, M., Falguères, C., Bahain, J.-J., Grün, R., Shao, Q., Aubert, M., Hellstrom, J., Dolo, J.-M., Agustí, J., Martínez-Navarro, B., Palmqvist, P., Toro-Moyano, I. (2011): The challenge of dating Early Pleistocene fossil teeth by the combined uranium series-electron spin resonance method: the Venta Micena palaeontological site (Orce, Spain). Journal of Quaternary Science 26, 603-615. doi: 10.1002/ jqs. 1476

Eronen, J.T., Rook, L. (2004): The Mio-Pliocene European primate fossil record: dynamics and habitat tracking. Journal of Human Evolution 47, 323-341. doi: 10.1016/j.jhevol2004.08.003

Estravís, C. (2000): Nuevos mamíferos del Eoceno Inferior de Silveirinha (Baixo Mondego, Portugal). Coloquios de Paleontología 51, 281-311.

Filhol, H. (1874): Nouvelles observations sur les mammifères des gisements de phosphates de chaux (lémuriens et pachylémuriens). Annales des Sciences Géologiques, Paris 5, 1-36.

Fleagle, J.G. (1999): Primate adaptation and evolution. Academic Press, San Diego: 596 p.

Fooden, J. (2007): Systematic review of the Barbary macaque, $M a-$ caca sylvanus (Linnaeus, 1758). Fieldiana Zoology 113, 1-60. doi: 10.5962/bhl.title.14256

Fortelius, M., Hokkanen, A. (2001): The trophic context of hominoid occurrence in the later Miocene of western Eurasia: a primate-free view. In: L. de Bonis, G.D. Koufos, P. Andrews (eds.), Hominoid Evolution and climatic change in Europe. Volume 2: Phylogeny of Neogene Primates of Eurasia. Cambridge University Press, Cambridge: $19-47$

Gebo, D.L. (2002): Adapiformes: Phylogeny and adaptation. 21-43. In: W.C. Hartwig (ed.), The Primate Fossil Record. Cambridge University Press, Cambridge: 21-43.

Gervais, P. (1876): Zoologie et paléontologie générale, Arthus Bertrand, Paris: $263 \mathrm{p}$.

Gheerbrant, E., Abrial, C., Cuenca, G. (1997): Nouveau mammifère condylarthre du Paléocène supérieur de Campo (Pyrénees aragonaises, Espagne). Comptes Rendues de l'Académies des Sciences de Paris 324, 599-606.

Gibert Clols, J., Pons Moyà, J. (1985): Estudio morfológico de la falange del género Homo de Cueva Victoria (Cartagena; Murcia). Paleontologia i Evolució 18, 49-55.

Gibert, J., Pérez-Pérez, A. (1989): A human phalanx from lower Paleolithic site of Cueva Victoria (Murcia, Spain). Human Evolution 4, 307-316.

Gibert, J., Pons, J., Ruz, M.C. (1985): Comparación métrica y morfológica de la falange del género Homo de Cueva Victoria (Cartagena, Murcia) con las de primates y úrsidos. Paleontologia i Evolució 19, 147-154.

Gibert, J., Ribot, F., Gibert, L., Leakey, M., Arribas, A., Martinez, B. (1995): Presence of the cercopithecid genus Theropithecus in Cueva Victoria (Murcia, Spain). Journal of Human Evolution 28, 487-493. doi: 10.1006/jhev.1995.1036

Gibert, J., Sanchez, F., Ribot, F., Gibert, L., Ferrandez, C., Iglesias, A., Gibert, P., González, F. (2002): Restes humains dans les sédiments du Pléistocène inférieur de la région d'Orce et de Cueva Victoria (sud-est de l'Espagne). L'Anthropologie 106, 669-683.

Gibert, J., Gibert, L., Ribot, F., Ferràndez-Canadell, C., Sánchez, F., Iglesias, A., Walker, M.J. (2008): CV-0, an early Pleistocene human phalanx from Cueva Victoria (Cartagena, Spain). Journal of Human Evolution 54, 150-156. doi: 10.1016/j.jhevol.2007.04.010

Gingerich, P.D. (1977): New species of Eocene primates and the phylo- geny of European Adapidae. Folia Primatologica 28, 60-80.

Ginsburg, L. (1986): Chronology of the European pliopithecids. In: J.G. Else, P.C. Lee (eds.), Primate Evolution. Cambridge University Press, Cambridge: 47-57.

Godinot, M. (1983): Contribution à l'étude des primates paleogènes d'Europe - systématique, locomotion. Université des Sciences et Techniques du Languedoc, Montpellier. Docteur d'État mention Sciences, $258 \mathrm{p}$.

Godinot, M. (1984): Un nouveau genre de Paromomyidae (Primates) de l'Eocène Inférieur d'Europe. Folia Primatologica 43, 84-96.

Godinot, M. (1988): Les primates adapidés de Bouxwiller (Eocène Moyen, Alsace) et leur apport à la compréhension de la faune de Messel et à l'évolution des Anchomomyini. Courier Forschungs-Institut Senckenberg 107, 383-407.

Godinot, M., Couette, S. (2008): Morphological diversity in the skulls of large adapines (Primates, Adapiformes) and its systematic implications. In: E.J. Sargis, M. Dagosto (eds.), Mammalian Evolutionary Morphology: A Tribute to Frederick Szalay, Springer, Dordrecht: 285-313.

Golpe Posse, J.M. (1982a): Los hispanopitecos (Primates, Pongidae) de los yacimientos del Vallès Penedès (Cataluña - España). I: Material ya descrito. Butlletí Informatiu de l'Institut de Paleontologia de Sabadell 14, 63-69.

Golpe Posse, J.M. (1982b): Un pliopitécido persistente en el Vallesiense Medio-Superior de los alrededores de Terrassa (cuenca del Vallés, España) y problemas de su adaptación. Boletín Geológico y Minero 93-94, 287-296.

Golpe-Posse, J.M. (1982c): Paleobiologia dels jaciments amb vertebrats al trànsit Eocè-Oligocè a la Catalunya central. Butlletí de la Institució Catalana d'Història Natural 48, 123-134.

Golpe Posse, J.M. (1993): Los Hispanopitecos (Primates, Pongidae) de los yacimientos del Vallès-Penedès (Cataluña, España). II: Descripción del material existente en el Instituto de Paleontología de Sabadell. Paleontologia i Evolució 26-27, 151-224.

Groves, C. (2001). Primate taxonomy. Smithsonian Institution Press, Washington DC: $350 \mathrm{p}$.

Grün, R., Maroto, J., Eggins, S., Stringer, C., Robertson, S., Taylor, S., Mortimer, G., McCulloch, M. (2006): ESR and U-series analyses of enamel and dentine fragments of the Banyoles mandible. Journal of Human Evolution 50, 347-358. doi: 10.1016/j.jhevol.2005.10.001

Guillén Castejón, J. (2010): Canal Negre 1, un jaciment càrstic de vertebrats del Miocè, Pliocè i Pleistocè de Catalunya. Exploracions 19, 7-87.

Gunnell, G.F., Rose, K.D. (2002): Tarsiiformes: Evolutionary history and adaptation. In: W.C. Hartwig (ed.) The primate fossil record, Cambridge University Press, Cambridge: 45-82.

Harrison, T. (1991): Some observations on the Miocene hominoids from Spain. Journal of Human Evolution 19, 515-520.

Harrison, T. (2005): The zoogeographic and phylogenetic relationships of early catarrhine primates in Asia. Anthropological Science 113, 43 51. doi: 10.1537 /ase.04S006

Harrison, T. (2010): Dendropithecoidea, Proconsuloidea, and Hominoidea (Catarrhini, Primates). In: L. Werdelin, W.J. Sanders (eds.), Cenozoic Mammals of Africa. University of California Press, Berkeley: 429-469.

Harrison, T., Gu, Y. (1999): Taxonomy and phylogenetic relationships of early Miocene catarrhines from Sihong, China. Journal of Human Evolution 37, 225-277. doi: 10.1006/jhev.1999.0310

Harrison, T., van der Made, J., Ribot, F. (2002): A new middle Miocene pliopithecid from Sant Quirze, northern Spain. Journal of Human Evolution 42, 371-377. doi: 10.1006/jhev.2001.0551

Hartwig, W.C. (editor) (2002): The primate fossil record. Cambridge University Press, Cambridge: 544 p.

Harvati, K., Hublin, J.-J., Gunz, P. (2010): Evolution of middle-late 
Pleistocene human cranio-facial form: A 3-D approach. Journal of Human Evolution 59, 445-464. doi: 10.1016/j.jhevol.2010.06.005

Heintz, E., Delson, E., Crusafont, M. (1971): Descubrimiento del género Macaca en el yacimiento de la Puebla de Valverde (Teruel). Boletín de la Real Sociedad Española de Historia Natural (Geología) 69, 299302.

Hoffstetter, R. (1974): Apidium et l'origine des Simiiformes (= Anthropoidea). Comptes Rendus de l'Academie des Sciences de Paris 278, 1715-1717.

Hoffstetter, R. (1982): Les Primates Simiiiformes (=Anthropoidea) (Compréhension, phylogénie, histoire biogéographique). Anales de Paléontologie 68, 241-290.

Hooker, J.J. (1986): Mammals from the Bartonian (middle/late Eocene) of the Hampshire Basin, Southern England. Bulletin of the British Museum (Natural History), Geology Series 39, 191-478.

Hooker, J.J., Collinson, M.E., Sille, N.P. (2004): Eocene-Oligocene mammalian faunal turnover in the Hampshire Basin, UK: calibration to the global time scale and the major cooling event. Journal of the Geological Society 161, 161-172. doi: 10.1144/0016-764903-091

Hsü, K.J., Cita, M.B., Ryan, W.B.F. (1973): The origin of the Mediterranean evaporites. Initial Reports of the Deep Sea Drilling Project 42, 1203-1231.

Hublin, J.-J. (2009): The origin of Neandertals. Proceedings of the National Academy of Sciences, U.S.A. 106, 16022-16027. doi: 10.1073/ pnas.0904119106

Hublin, J.-J., Barroso Ruiz, C., Medina Lara, P., Fontugne, M., Reyss, J.-L. (1995): The Mousterian site of Zafarraya (Andalucia, Spain): dating and implications on the paleolithic peopling process of Western Europe. Comptes Rendus de l'Académie des Sciences de Paris 321, 931-937.

Jablonski, N. G. (2002): Fossil Old World monkeys: the late Neogene radiation. In: W.C. Hartwig (ed.), The Primate Fossil Record. Cambridge University Press, Cambridge: 255-299.

Jablonski, N., Frost, S. (2010): Cercopithecoidea. In: L. Werdelin, W.J. Sanders (eds.), Cenozoic Mammals of Africa. University of California Press, Berkeley: 393-428.

Jablonski, N.G., Kelley, J. (1997): Did a major immunological event shape the evolutionary histories of apes and Old World monkeys? Journal of Human Evolution 33, 513-520. doi: 10.1006/jhev.1997.0160

Kelley, J. (2002): The hominoid radiation in Asia. In: W.C. Hartwig (ed.), The Primate Fossil Record. Cambridge University Press, Cambridge: $369-384$.

Köhler, M., Moyà-Solà, S. (1999): A finding of Oligocene primates on the European continent. Proceedings of the National Academy of Sciences, U.S.A. 96, 14664-14667. doi: 10.1073/pnas.96.25.14664

Köhler, M., Moyà-Solà, S., Andrews, P. (1999): Order Primates. In: G.E. Rössner, K. Heissig (eds.), The Miocene Land Mammals of Europe. Verlag Fritz Pfeil, München: 91-104..

Köhler, M., Moyà-Solà, S. Alba, D.M. (2000): Macaca (Primates, Cercopithecidae) from the Late Miocene of Spain. Journal of Human Evolution 38, 447-452. doi: 10.1006/jhev.1999.0388

Köhler, M., Moyà-Solà, S., Alba, D.M. (2001a): Eurasian hominoid evolution in the light of recent Dryopithecus findings. In: L. de Bonis, G.D. Koufos, P. Andrews (eds.), Hominoid evolution and climatic change in Europe, Vol. 2. Phylogeny of the Neogene hominoid primates of Eurasia. Cambridge University Press, Cambridge: 192-212.

Köhler, M., Moyà-Solà, S., Alba, D.M. (2001b): Cranial reconstruction of Dryopithecus. American Journal of Physical Anthropology 115, 284-288. doi: 10.1002/ajpa.1082

Köhler, M., Alba, D.M., Moyà-Solà, S., MacLatchy, L. (2002): Taxonomic affinities of the Eppelsheim femur. American Journal of Physical Anthropology 119, 297-304. doi: 10.1002/ajpa.10140

Koufos, G.D. (2009): The Neogene cercopithecoids (Mammalia, Primates) of Greece. Geodiversitas 31, 817-850. doi: 10.5252/ g2009n4a817

Kovar-Eder, J. (2003): Vegetation dynamics in Europe during the Neogene. Deinsea 10, 373-392.

Kunimatsu, Y., Ratanasthien, B., Nakaya, H., Saegusa, H., Nagaoka, S. (2004): Earliest Miocene hominoid from Southeast Asia. American Journal of Physical Anthropology 124, 99-108. doi: 10.1002/ ajpa. 10344

López-Martínez, N., Peláez-Campomanes, P. (1999): New mammals from south-central Pyrenees (Tremp Formation, Spain) and their bearing on late Paleocene marine-continental correlations. Bulletin de la Société Géologique de France 170, 681-696.

Lorenzo, C., Arsuaga, J.L., Carretero, J.M. (1999): Hand and foot remains from the Gran Dolina Early Pleistocene site (Sierra de Atapuerca, Spain). Journal of Human Evolution 37, 501-522. doi: 10.1006/ jhev.1999.0341

Lourens, L., Hilgen, F., Shackleton, N.J., Laskar, J., Wilson, D. (2004): The Neogene period. In: F.M. Gradstein, J.G. Ogg, A.G Smith (eds.), A Geologic Time Scale 2004. Cambridge University Press, Cambridge: $409-452$.

Luterbacher, H.P., Ali, J.R., Brinkhuis, H., Gradstein, F.M., Hooker, J.J., Monechi, S., Ogg, J.G., Powell, J., Röhl, U., Sanfilippo, A., Schmitz, B. (2004): The Paleogene period. In: F.M. Gradstein, J.G. Ogg, A.G Smith (eds.), A Geologic Time Scale 2004. Cambridge University Press, Cambridge: $384-408$.

MacDonald, J.R. (1963): The Miocene faunas from the Wounded Knee area of western South Dakota. Bulletin of the American Museum of Natural History 125, 139-238.

Madurell-Malapeira, J., Minwer-Barakat, R., Alba, D.M., Garcés, M., Gómez, M., Aurell-Garrido, J., Ros-Montoya, S., Moyà-Solà, S., Berástegui, X. (2010): The Vallparadís section (Terrassa, Iberian Peninsula) and the latest Villafranchian faunas of Europe. Quaternary Science Reviews 29, 3972-3982. doi: 10.1016/j.quascirev.2010.09.020

Madurell-Malapeira, J., Alba, D.M., Minwer-Barakat, R., AurellGarrido, J., Moyà-Solà, S. (2012): Early human dispersals into the Iberian Peninsula: A comment on Martínez et al. (2010) and Garcia et al. (2011). Journal of Human Evolution 62, 169-173. doi: 10.1016/j. jhevol.2011.10.005

Marigó, J., Minwer-Barakat, R., Moyà-Solà, S., Roig, I. (2009): Middle Eocene primates from Mazaterón (Almazán Basin, Soria): Preliminary report. Paleolusitana 1, 257-260.

Marigó, J., Minwer-Barakat, R., Moyà-Solà, S. (2010): New Anchomomyini (Adapoidea, Primates) from the Mazaterón Middle Eocene locality (Almazán Basin, Soria, Spain). Journal of Human Evolution 58, 353-361. doi: 10.1016/j.jhevol.2010.01.011

Marigó, J., Minwer-Barakat, R., Moyà-Solà, S. (2011a): New Anchomomys (Adapoidea, Primates) from the Robiacian (Middle Eocene) of northeastern Spain. Journal of Human Evolution 60, 665-672. doi: 10.1016/j.jhevol.2010.12.006

Marigó, J., Minwer-Barakat, R., Moyà-Solà, S. (2011b): Estado actual del conocimiento sobre los primates del Paleógeno de la Península Ibérica. Paleontologia i Evolució memòria especial núm. 5, 219-222.

Marigó, J., Minwer-Barakat, R., Moyà-Solà, S. (2011c): Paleogene primates from the Iberian Peninsula: Past, present and future. In: T. Lehmann, S.F.K. Schaal (eds.), The world at the time of Messel: Puzzles in palaeobiology, palaeoenvironment, and the history of early primates. 22nd International Senckenberg Conference. 15th-19th November 2011, Frankfurt am Main. Conference volume. Senckenberg Gesellschaft für Naturforschung, Frankfurt am Main: 108-109.

Marigó, J., Minwer-Barakat, R., Moyà-Solà, S., López-Torres, S. (2012a): First record of Plesiadapiformes (Primates, Mammalia) from Spain. Journal of Human Evolution 62, 429-433. doi: 10.1016/j.jhevol.2012.01.002

Marigó, J., Minwer-Barakat, R., Moyà-Solà, S. (2012b): New material of Anchomomys (Adapoidea, Primates) from the Spanish fossil site 
of Caenes (Salamanca) [Abstract]. American Journal of Physical Anthropology 147, S54, 203-204.

Marigó, J., Minwer-Barakat, R., Moyà-Solà, S. (2013): Nievesia sossisensis, a new anchomomyin (Adapiformes, Primates) from the early Late Eocene of the southern Pyrenees (Catalonia, Spain). Journal of Human Evolution 64, 473-485. doi: 10.1016/j.jhevol.2012.11.004

Marmi, J., Casanovas-Vilar, I., Robles, J.M., Moyà-Solà, S., Alba, D.M. (2012): The paleoenvironment of Hispanopithecus laietanus as revealed by paleobotanical evidence from the Late Miocene of Can Llobateres 1 (Catalonia, Spain). Journal of Human Evolution 62, $412-$ 423. doi: 10.1016/j.jhevol.2011.12.003

Maroto, J., Soler, N., Mir, A. (1987): La Cueva de Mollet I. Cypsela 6, 101-110.

Maroto, J., Julià, R., López-García, J.M., Blain, H.-A. (2012): Chronological and environmental context of the Middle Pleistocene human tooth from Mollet Cave (Serinyà, NE Iberian Peninsula). Journal of Human Evolution 62, 655-663. doi: 10.1016/j.jhevol.2012.01.009

Martin, R.D. (1990): Primate Origins and Evolution. A Phylogenetic Reconstruction. Princeton University Press, Princeton: 840 p.

Martín Penela, A. (1983): Presencia del género Macaca en el yacimiento Pleistoceno de la Solana del Zamborino (Fonelas, Granada, España). Estudio preliminar. Boletín de la Real Sociedad Española de Historia Natural (Geología) 81, 187-195.

Martín Penela, A. (1988): Los grandes mamíferos del yacimiento achelense de la Solana del Zamborino, Fonelas (Granada, España). Antropología y Paleoecologia Humana 5, 29-187.

Martínez-Navarro, B. (2002): The skull of Orce: parietal bones or frontal bones? Journal of Human Evolution 42, 265-270. doi: 10.1006/ jhev.2002.0566

Martínez-Navarro, B., Turq, A., Agustí Ballester, J., Oms, O. (1997): Fuente Nueva-3 (Orce, Granada, Spain) and the first human occupation of Europe. Journal of Human Evolution 33, 611-620. doi: 10.1006/jhev.1997.0158

Martínez-Navarro, B., Claret, A., Shabel, A.B., Pérez Claros, J.A., Lorenzo, C., Palmqvist, P. (2005): Early Pleistocene "hominid remains" from southern Spain and the taxonomic assignment of the Cueva Victoria phalanx. Journal of Human Evolution 48, 517-523. doi: 10.1016/j.jhevol.2005.02.003

Martínez-Navarro, B., Palmqvist, P., Shabel, A.B., Pérez-Claros, J.A., Lorenzo, C., Claret, A. (2008): Reply to Gibert et al. (2008) on the supposed human phalanx from Cueva Victoria (Cartagena, Spain). Journal of Human Evolution 54, 157-161. doi: 10.1016/j.jhevol.2007.09.011

Martinón-Torres, M., Martín-Francés, L., Gracia, A., Olejniczak, A., Prado-Simón, L., Gómez-Robles, A., Lapresa, M., Carbonell, E., Arsuaga, J.L., Bermúdez de Castro, J.M. (2011): Early Pleistocene human mandible from Sima del Elefante (TE) cave site in Sierra de Atapuerca (Spain): A palaeopathological study. Journal of Human Evolution 61, 1-11. doi: 10.1016/j.jhevol.2011.01.004

Martinón-Torres, M., Bermúdez de Castro, J.M., Gómez Robles, A., Prado-Simón, L., Arsuaga, J.L. (2012): Morphological description and comparison of the dental remains from Atapuerca-Sima de los Huesos site (Spain). Journal of Human Evolution 62, 7-58. doi: 10.1016/j.jhevol.2011.08.007

Mein, P., Moissenet, E., Adrover, R. (1990): Biostratigraphie du Néogène Supérieur du bassin de Teruel. Paleontologia i Evolució 23, 121 139.

Minwer-Barakat, R., Marigó, J., Moyà-Solà, S. (2010): A new species of Pseudoloris (Omomyidae, Primates) from the Middle Eocene of Sant Jaume de Frontanyà (Eastern Pyrenees, Spain). American Journal of Physical Anthropology 143, 92-99. doi: 10.1002/ajpa.21297

Minwer-Barakat, R., Marigó, J., Moyà-Solà, S. (2011a): El excepcional registro de primates del Eoceno Medio de Sant Jaume de Frontanyà (Pirineos Orientales, Noreste de España). Paleontologia i Evolució memòria especial núm. 5, 255-258.

Minwer-Barakat, R., Marigó, J., Badiola, A., Moyà-Solà, S. (2011b). New discoveries of microchoerines (Omomyidae, Primates) from the Eocene of the Iberian Peninsula [Abstract]. Journal of Vertebrate Paleontology 31 (Suppl. 2), 159.

Minwer-Barakat, R., Marigó, J., Moyà-Solà, S. (2012): Pseudoloris cuestai, a new microchoerine (Primates, Omomyidae) from the middle Eocene of the Iberian Peninsula. Journal of Vertebrate Paleontology 32, 407-418. doi: 10.1080/02724634.2012.643330

Minwer-Barakat, R., García-Alix, A., Martín Suárez, E., Freudenthal, M., Viseras, C. (2012): Micromammal biostratigraphy of the Upper Miocene to lowest Pleistocene continental deposits of the Guadix Basin, southern Spain. Lethaia 45, 594-614. doi: 10.1111/j.15023931.2012.00324.x

Minwer-Barakat, R., Badiola, A., Marigó, J., Moyà-Solà, S. (2013a). First record of the genus Microchoerus (Omomyidae, Primates) in the western Iberian Peninsula and its palaeobiogeographic implications. Journal of Human Evolution 65, 313-321. doi: 10.1016/j. jhevol.2013.07.002

Minwer-Barakat, R., Marigó, J., Moyà-Solà, S. (2013b). Redescription and designation of a neotype for Pseudoloris reguanti CrusafontPairó, 1967, an Eocene primate from the Iberian Peninsula. American Journal of Physical Anthropology 151, 245-251. doi: 10.1002/ ajpa. 22277

Montoya, P., Alberdi, M.T., Blázquez, A.M., Barbadillo, L.J., Fumanal, M.P., van der Made, J., Marín, J.M., Molina, A., Morales, J., Murelaga, X., Peñalver, E., Robles, F., Ruiz Bustos, A., Sánchez, A., Sanchiz, B., Soria, D., Szyndlar, Z. (1999): La fauna del Pleistoceno Inferior de la Sierra de Quibas (Abanilla, Murcia). Estudios Geológicos 55, 127-161.

Montoya, P., Alberdi, M.T., Barbadillo, L.J., van der Made, J., Morales, J., Murelaga, X., Peñalver, E., Robles, F., Ruiz Bustos, A., Sánchez, A., Sanchiz, B., Soria, D., Szyndlar, Z. (2001): Une faune très diversifiée du Pléistocène inférieur de la Sierra de Quibas (province du Murcia, Espagne). Comptes Rendus de l'Académie des Sciences de Paris 332, 387-393. doi: 10.1016/S1251-8050(01)01544-0

Montoya, P., Abella, J., Figueirido, B., Benavent, J.V. (2002): Venta del Moro, uno de los principales yacimientos de vertebrados terciarios de la península Ibérica. Cidaris 21-22, 13-20.

Montoya, P., Morales, J., Robles, F., Abella, J., Benavent, J.V., Marín, M.D., Ruiz Sánchez, F.J. (2006): Las nuevas excavaciones (19952006) en el yacimiento del Mioceno final de Venta del Moro, Valencia. Estudios Geológicos 62, 313-325.

Mosbrugger, V., Utescher, T., Dilcher, D.L. (2005): Cenozoic climatic evolution of Central Europe. Proceedings of the National Academy of Sciences, U.S.A. 102, 15964-14969. doi: 10.1073/pnas.0505267102

Mounier, A., Marchal, F., Condemi, S. (2009): Is Homo heidelberensis a distinct species? New insight on the Mauer mandible. Journal of Human Evolution 56, 219-246. doi: 10.1016/j.jhevol.2008.12.006

Moyà-Solà, S., Köhler, M. (1992): Los primates del Paleógeno de Castilla y León: Una introducción. In: E. Jiménez-Fuentes (ed.), Vertebrados Fósiles de Castilla y León. Museo de Salamanca, Salamanca: 121-125.

Moyà-Solà, S., Köhler, M. (1993a): Recent discoveries of Dryopithecus shed new light on evolution of great apes. Nature 365, 543-545. doi: 10.1038/365543a0

Moyà-Solà, S., Köhler, M. (1993b): Middle Bartonian locality with Anchomomys (Adapidae, Primates) in the Spanish Pyrenees: Preliminary Report. Folia Primatologica 60, 158-163.

Moyà-Solà, S., Köhler, M. (1995): New partial cranium of Dryopithecus Lartet, 1863 (Hominoidea, Primates) from the upper Miocene of Can Llobateres, Barcelona, Spain. Journal of Human Evolution 29, 101139. doi: 10.1006/jhev.1995.1049

Moyà-Solà, S., Köhler, M. (1996): A Dryopithecus skeleton and 
the origins of great-ape locomotion. Nature 379, 156-159. doi: $10.1038 / 379156 \mathrm{a} 0$

Moyà-Solà, S., Köhler, M. (1997): The Orce skull: anatomy of a mistake. Journal of Human Evolution 33, 91-97. doi: 10.1006/jhev.1997.0121

Moyà Solà, S., Pons Moyà, J., Köhler, M. (1990): Primates catarrinos (Mammalia) del Neógeno de la península Ibérica. Paleontologia $i$ Evolució 23, 41-45.

Moyà-Solà, S., Köhler, M., Alba, D.M. (2001): Egarapithecus narcisoi, a new genus of Pliopithecidae (Primates, Catarrhini) from the Late Miocene of Spain. American Journal of Physical Anthropology 114, 312-324. doi: 10.1002/ajpa.1043

Moyà-Solà, S., Köhler, M., Alba, D.M., Casanovas-Vilar, I., Galindo, J. (2004): Pierolapithecus catalaunicus, a new Middle Miocene great ape from Spain. Science 306, 1339-1344. doi: 10.1126/science. 1103094

Moyà-Solà, S., Köhler, M., Alba, D.M., Casanovas-Vilar, I., Galindo, J. (2005): Response to comment on "Pierolapithecus catalaunicus, a new Middle Miocene great ape from Spain”. Science 308, 203d. doi: 10.1126/science. 1108433

Moyà-Solà, S., Köhler, M., Alba, D.M., Casanovas-Vilar, I., Galindo, J., Robles, J.M., Cabrera, L., Garcés, M., Almécija, S., Beamud, E. (2009a): First partial face and upper dentition of the Middle Miocene hominoid Dryopithecus fontani from Abocador de Can Mata (VallèsPenedès Basin, Catalonia, NE Spain): taxonomic and phylogenetic implications. American Journal of Physical Anthropology 139, 126145. doi: 10.1002/ajpa.20891

Moyà-Solà, S., Alba, D.M., Almécija, S., Casanovas-Vilar, I., Köhler, M., De Esteban-Trivigno, S., Robles, J.M., Galindo, J., Fortuny, J. (2009b): A unique Middle Miocene European hominoid and the origins of the great ape and human clade. Proceedings of the National Academy of Sciences, U.S.A. 106, 9601-9606. doi: 10.1073/ pnas.0811730106

Moyà-Solà, S., Köhler, M., Alba, D.M., Roig, I. (2012): Calcaneal proportions in primates and locomotor inferences in Anchomomys and other Palaeogene Euprimates. Swiss Journal of Palaeontology 131, 147-159. doi: 10.1007/s13358-011-0032-5

Oms, O., Parés, J.M., Martínez-Navarro, B., Agustí, J., Toro, I., Martínez-Fernández, G., Turq, A. (2000): Early human occupation of Western Europe: paleomagnetic dates for two paleolithic sites in Spain. Proceedings of the National Academy of Sciences, U.S.A. 97, 10666-10670. doi: 10.1073/pnas.180319797

Peláez-Campomanes, P. (1995): Primates and rodents from the Middle Eocene of Casa Ramón (Huesca, Spain). Proceedings of the Koninklijke Nederlandse Akademie van Wetenschappen 98, 291-312.

Peláez-Campomanes, P. (2000): Mammalian faunas from the Paleogene of the Sierra Palomera (Teruel, Spain). Journal of Paleontology 74, 336-348. doi: 10.1666/0022-3360(2000)074

Peláez-Campomanes, P., De la Peña, A., López Martínez, N. (1989): Primeras faunas de micromamíferos del Paleógeno de la cuenca del Duero. Stvdia Geologica Salmanticensia Vol. Esp. 5, 135-157.

Peláez-Campomanes, P., López-Martínez, N., Álvarez-Sierra, M.A., Daams, R. (2000): The earliest mammal of the European Paleocene: the multituberculate Hainina. Journal of Paleontology 74, 701-711.

Pérez, B., Soria, D. (1990): Análisis de las comunidades de mamíferos del Plioceno de Layna (Soria) y La Calera (Teruel). Paleontologia $i$ Evolució 23, 231-238.

Pérez de los Ríos, M., Moyà-Solà, S., Alba, D.M., Fortuny, J. (2010): Maxillary and frontal sinuses in Eurasian Miocene hominoids: phylogenetic implications. Cidaris 30, 223-226.

Pérez de los Ríos, Moyà-Solà, S., Alba, D.M. (2012): The nasal and paranasal architecture of the Middle Miocene ape Pierolapithecus catalaunicus (Primates: Hominidae): Phylogenetic implications. Journal of Human Evolution 63, 497-506. doi: 10.1016/j.jhevol.2012.05.012

Pérez-Ripoll, M. (1977): Los mamíferos del yacimiento musteriense de
Cova Negra. Trabajos varios del SIP 53, València.

Pickford, M. (2012): Hominoids from Neuhausen and other Bohnerz localities, Swabian Alb, Germany: evidence for a high diversity of apes in the Late Miocene of Germany. Estudios Geológicos 68, 113-147. doi: 10.3989/egeol.40322.129

Pike, A.W.G., Hoffmann, D.L., García-Diez, M., Pettitt, P.B., Alcolea, J., De Balbín, R., González-Sainz, C., de las Heras, C., Lasheras, J.A., Montes, R., Zilhão, J. (2012): U-series dating of Paleolithic art in 11 caves in Spain. Science 336, 1409-1413. doi: 10.1126/science. 1219957

Pina, M., Alba, D.M., Almécija, S., Fortuny, J., Moyà-Solà, S. (2012a): Locomotor inferences in Hispanopithecus laietanus on the basis of its femoral neck cortical thickness [Abstract]. American Journal of Physical Anthropology 147, S54, 237.

Pina, M., Alba, D.M., Almécija, S., Fortuny, J., Moyà-Solà, S. (2012b, published online): Brief Communication: Paleobiological inferences on the locomotor repertoire of extinct hominoids based on femoral neck cortical thickness: the fossil great ape Hispanopithecus laietanus as a test-case study. American Journal of Physical Anthropology. doi: 10.1002/ajpa.22109

Prothero, D.R. (1994): The late Eocene-Oligocene extinctions. Annual Reviews of the Earth and Planetary Sciences 22, 145-165.

Quam, R.M., Arsuaga, J.L., Bermúdez de Castro, J.M., Díez, J.C., Lorenzo, C., Carretero, J.M., García, N., Ortega, A.I. (2001): Human remains from Valdegoba Cave (Huérmeces, Burgos, Spain). Journal of Human Evolution 41, 385-435. doi: 10.1006/jhev.2001.0486

Rasmussen, D.T. (2002): The origin of primates. In: W.C. Hartwig (Ed.) The Primate Fossil Record. Cambridge University Press, Cambridge: 5-9.

Ribot, F., Gibert, J., Harrison, T. (1996): A reinterpretation of the taxonomy of Dryopithecus from Vallès-Penedès, Catalonia (Spain). Journal of Human Evolution 31, 129-141. doi: 10.1006/jhev.1996.0054

Rightmire, G.P. (1998): Human evolution in the Middle Pleistocene: the role of Homo heidelbergensis. Evolutionary Anthropology 6, 218-227. doi: 10.1002/(SICI)1520-6505(1998)6:6<218::AIDEVAN4>3.0.CO;2-6

Rightmire, G.P. (2007): Later middle Pleistocene Homo. In: W. Henke, I. Tattersall (eds.), Handbook of Paleoanthropology. Phylogeny of Hominins, vol. 3. Springer Verlag, Berlin: 1695-1715.

Rightmire, G.P. (2008): Homo in the middle Pleistocene: hypodigms, variation, and species recognition. Evolutionary Anthropology 17, 8-21. doi: 10.1002/evan.20160

Roig, I., Moyà-Solà, S. (2011): Interpretaciones preliminares sobre la locomoción de Anchomomys frontanyensis (Adapoidea, Primates) a partir del estudio morfológico del primer metatarso. Paleontologia $i$ Evolució memòria especial núm. 5, 333-337.

Rook, L., Martínez-Navarro, B. (2010): Villafranchian: The long story of a Plio-Pleistocene European large mammal biochronologic unit. Quaternary International 219, 134-144. doi: 10.1016/j. quaint.2010.01.007

Rook, L., Mottura, A., Gentili, S. (2001): Fossil Macaca remains from RDB quarry (Villafranca d'Asti, Italy): new data and overview. Journal of Human Evolution 40, 187-202. doi: 10.1006/jhev.2000.0449

Rosas, A., Martínez-Maza, C., Bastir, M., García-Tabernero, A., Lalueza-Fox, C., Huguet, R., Ortiz, J.E., Julià, R., Soler, V., de Torres, T., Martínez, E., Cañaveras, J.C., Sánchez-Moral, S., Cuezva, S., Lario, J., Santamaría, D., de la Rasilla, M., Fortea, J. (2006): Paleobiology and comparative morphology of a late Neandertal sample from El Sidrón, Asturias, Spain. Proceedings of the National Academy of Sciences, U.S.A. 103, 19266-19271. doi: 10.1073/pnas.0609662104

Rosenberger, A.L. (2006): Protoanthropoidea (Primates, Simiiformes): A new primate higher taxon and a solution to the Rooneyia problem. Journal of Mammalian Evolution 13, 139-146. doi: 10.1007/s10914006-9009-3

Sanchez, F. (1999): Comparative biometrical study of the Mousterian 
mandible from Cueva del Boquete de Zafarraya (Málaga, Spain). Human Evolution 14, 125-138.

Schmidt-Kittler, N. (1971): Eine unteroligozäne Primatenfauna von Ehrenstein beil Ulm. Mitteilungen der bayerische Staatssammlungen für Paläontologie und historische Geologie 11, 171-204.

Schmidt-Kittler N. (1977): Neue Primatenfunde aus unteroligozänen Karstspaltenfüllungen Süddeutschlands. Mitteilungen der bayerische Staatssammlungen für Paläontologie und historische Geologie 17, 177-195.

Silcox, M.T. (2001): A phylogenetic analysis of Plesiadapiformes and their relationship to Euprimates and other archontans. Johns Hopkins University, Ph.D. Dissertation.

Simons, E.L., Bown, T.M., Rasmussen, D.T. (1986): Discovery of two additional prosimian primate families (Omomyidae, Lorisidae) in the African Oligocene. Journal of Human Evolution 15, 431-437. doi: 10.1016/S0047-2484(86)80026-4

Smith, T., Dupuis, C., Folie, A., Quesnel, F., Storme, J.-Y., Iacumin, P., Riveline, J., Missiaen, P., Ladevèze, S., Yans, J. (2011). A new terrestrial vertebrate site just after the Paleocene-Eocene boundary in the Mortemer Formation of Upper Normandy, France. Comptes Rendus Palevol 10, 11-20. doi: 10.1016/j.crpv.2010.11.004

Stehlin, H.G. (1910). Remarques sur les faunules de Mammifères des couches Éocènes et Oligocènes du Bassin de Paris. Bulletin de la Société Geologique de France 9, 488-520.

Steiper, M.E., Seiffert, E.R. (2012). Evidence for a convergent slowdown in primate molecular rates and its implications for the timing of early primate evolution. Proceedings of the National Academy of Sciences, U.S.A. doi: 10.1073/pnas.1119506109

Stringer, C. (2012): The status of Homo heidelbergensis (Schoetensack 1908). Evolutionary Anthropology 21, 101-107. doi: 10.1002/ evan. 21311

Susanna, I., Alba, D.M., Almécija, S., Moyà-Solà, S. (2010): The lumbar vertebrae of the Middle Miocene stem great ape Pierolapithecus catalaunicus (Primates: Hominidae) [Abstract]. American Journal of Physical Anthropology 141, S50, 227.

Susanna, I., Alba, D.M., Almécija, S., Moyà-Solà, S. (2011): Vertebral remains of the Late Miocene ape Hispanopithecus laietanus (Primates: Hominidae): Functional morphology and paleobiological implications [Abstract]. Journal of Vertebrate Paleontology 31 (Suppl. 2), 202.

Szalay, F.S. (1971): The European adapid primates Agerina and Pronycticebus. American Museum Novitates 2466, 1-19.

Szalay, F., Delson, E. (1979): Evolutionary History of the Primates. Academic Press, New York: 580 p.

Tattersall, I., Schwartz, J.H. (1999): Hominids and hybrids: The place of Neanderthals in human evolution. Proceedings of the National Academy of Sciences, U.S.A. 96, 7117-7119. doi: 10.1073/pnas.96.13.7117

Trinkaus, E. (2007): European early modern humans and the fate of the Neandertals. Proceedings of the National Academy of Sciences, U.S.A. 104, 7367-7372. doi: 10.1073/pnas.0702214104

Trinkaus, E., Bailey, S.E., Zilhão, J. (2001): Upper Paleolithic human remains from the Gruta do Caldeirão, Tomar, Portugal. Revista Portuguesa de Arqueologia 4, 5-17.

Trinkaus, E., Marks, A.E., Brugal, J. P., Bailey, S.E., Rink, W.J., Richter, D. (2003): Later Middle Pleistocene human remains from the Almonda Karstic system, Torres Novas, Portugal. Journal of Human Evolution 45, 219-226. doi: 10.1016/j.jhevol.2003.07.001
Trinkaus, E., Maki, J., Zilhão, J. (2007): Middle Paleolithic human remains from the Gruta da Oliveira (Torres Novas), Portugal. American Journal of Physical Anthropology 134, 263-273. doi: 10.1002/ ajpa.20669

van der Made, J., Ribot, F. (1999): Additional hominoid material from the Miocene of Spain and remarks on hominoid dispersals into Europe. Contributions to Tertiary and Quaternary Geology 36, 25-39.

van der Made, J., Morales, J., Montoya, P. (2006): Late Miocene turnover in the Spanish mammal record in relation to palaeoclimate and the Messinian Salinity Crisis. Palaeogeography, Palaeoclimatolology, Palaeoecology 238, 28-246. doi: 10.1016/j.palaeo.2006.03.030

van der Meulen, A.J., García-Paredes, I., Álvarez-Sierra, M.A., van den Hoek Ostende, L.W., Hordijk, K., Oliver, A., López-Guerrero, P., Hernández-Ballarín, V., Pélaez-Campomanes, P. (2011): Biostratigraphy or biochronology? Lessons from the Early and Middle Miocenes small Mammal Events in Europe. Geobios 44, 309-321. doi: 10.1016/j.geobios.2010.11.004

Vidal, L.M. (1913a): Nota sobre la presencia del "Dryopithecus" en el mioceno superior del Pirineo catalán. Boletín de la Real Sociedad española de Historia natural 13, 499-507.

Vidal, L.M. (1913b): Sobre la presència del "Dryopithecus" en el Miocè superior del Pirineu català. Treballs de la Societat de Biologia 1, 247-256.

Villalta Comella, J.F. de, Crusafont Pairó, M. (1941): Hallazgo del "Dryopithecus fontani", Lartet, en el Vindoboniense de la cuenca Vallés-Penedés. Boletín del Instituto Geológico y Minero de España 20, 1-15.

Villalta Comella, J.F. de, Crusafont Pairó, M. (1944). Dos nuevos antropomorfos del Mioceno español y su situación dentro de la moderna sistemática de los símidos. Notas y Comunicaciones del Instituto Geológico y Minero de España 13, 1-51.

Walker, M.J., Gibert, J., López, M.V., Lombardi, A.V., Pérez-Pérez, A., Zapata, J., Ortega, J., Higham, T., Pike, A., Schwenninger, J.-L., Zilhao, J., Trinkaus, E. (2008): Late Neandertals in Southeastern Iberia: Sima de las Palomas del Cabezo Gordo, Murcia, Spain. Proceedings of the National Academy of Sciences, U.S.A. 105, 20631-20636. doi: 10.1073/pnas.0811213106

Walker, M.J., López Martínez, M., Haber Uriarte, M., López Jiménez, A., Ortega Rodrigáñez, J., Parmová, K., Fernández-Avilés, A., Campillo Boj, M. (2010): La Cueva Negra del Estrecho del Río Quípar en Caravaca de la Cruz y la Sima de las Palomas del Cabezo Gordo en Torre Pacheco: Dos ventanas sobre la vida y la muerte del hombre fósil en Murcia. Eubacteria 24, 1-13.

Walker, M.J., Ortega, J., López, M.V., Parmová, K., Trinkaus, E. (2011): Neandertal postcranial remains from the Sima de las Palomas del Cabezo Gordo, Murcia, southeastern Spain. American Journal of Physical Anthropology 144, 505-515. doi:10.1002/ajpa.21428

Ward, C. (2007): Postcranial and locomotor adaptations of hominoids. In: W. Henke, I. Tattersall (eds.), Handbook of Paleoanthropology. Springer Verlag, Heidelberg: 1011-1030.

Woodward, A.S. (1914): On the lower jaw of an anthropoid ape (Dryopithecus) from the Upper Miocene of Lérida (Spain). Quarterly Journal of the Geological Society 70, 316-320.

Zachos, J., Pagani, M., Sloan, L., Thomas, E., Billups, K. (2001): Trends, rhythms and aberrations in global climate 65 Ma to present. Science 292, 686-693. doi: 10.1126/science. 1059412 